https://helda.helsinki.fi

\title{
Expression, activity and pharmacokinetic impact of ocular transporters
}

\section{Vellonen, Kati-Sisko}

2018-02-15

\begin{abstract}
Vellonen , K-S , Hellinen , L , Mannermaa , E , Ruponen , M , Urtti , A \& Kidron , H 2018 , ' Expression, activity and pharmacokinetic impact of ocular transporters ' , Advanced Drug Delivery Reviews , vol. 126 , pp. 3-22 . https://doi.org/10.1016/j.addr.2017.12.009
\end{abstract}

http://hdl.handle.net/10138/307629

https://doi.org/10.1016/j.addr.2017.12.009

cc_by_nc_nd

acceptedVersion

Downloaded from Helda, University of Helsinki institutional repository.

This is an electronic reprint of the original article.

This reprint may differ from the original in pagination and typographic detail.

Please cite the original version. 
Expression, activity and pharmacokinetic impact of ocular transporters

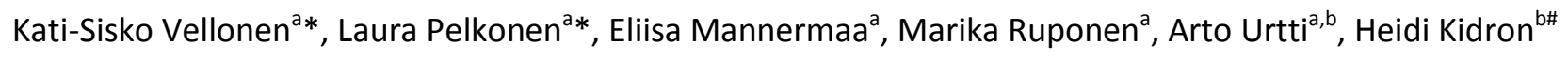

*equal contribution

${ }^{a}$ School of Pharmacy, University of Eastern Finland, Kuopio, Finland

${ }^{b}$ Centre for Drug Research, Division of Pharmaceutical Biosciences, University of Helsinki, Helsinki, Finland

\#Corresponding author: Centre for Drug Research, Division of Pharmaceutical Biosciences, P.O. Box 56, 00014

University of Helsinki, Finland. Email address: heidi.kidron@helsinki.fi

\begin{abstract}
The eye is protected by several tissues that limit the permeability and entry of potentially harmful substances, but also hamper the delivery of drugs in the treatment of ocular diseases. Active transport across the ocular barriers may affect drug distribution, but the impact of drug transporters on ocular drug delivery is not well known. We have collected and critically reviewed the literature for ocular expression and activity of known drug transporters. The review concentrates on drug transporters that have been functionally characterized in ocular tissues or primary cells and on transporters for which there is available expression data at the protein level. Species differences are highlighted, since these may explain observed inconsistencies in the influence of specific transporters on drug disposition. There is variable evidence about the pharmacokinetic role of transporters in ocular tissues. The strongest evidence for the role of active transport is available for the bloodretinal barrier. We explored the role of active transport in the cornea and blood retinal barrier with pharmacokinetic simulations. The simulations show that the active transport is important only in the case of specific parameter combinations.
\end{abstract}

\title{
Keywords
}

Active transport, blood-retinal barrier, blood-aqueous barrier, conjunctiva, cornea, neural retina, pharmacogenetics

\section{Abbreviations}

$A B C, A T P-b i n d i n g ~ c a s s e t t e ; A H U I$, aqueous humour uptake index; AUC, area under the curve; $B A B$, bloodaqueous barrier; $B B B$, blood-brain barrier; BCRP, breast cancer resistance protein; BRB, blood-retinal barrier; $B U I$, brain uptake index; MATE1, multidrug and toxin extrusion protein 1; $M C T$, monocarboxylate transporter; MDR1, multidrug resistance protein 1; MRP, multidrug resistance associated protein; NPE, nonpigmented epithelial cell layer; OAT, organic anion transporters; OATP, organic anion transporting polypeptides; OCT, organic cation transporter; PCFT, proton-coupled folate transporter ; PE, pigmented epithelial cell layer; QSPR, quantitative structure-property relationship; RFC1, reduced folate carrier 1; RPE, retinal pigment epithelium; SLC, solute carrier; TEA, tetraethylammonium. 
Table of contents

1. Introduction

2. Transporters in ocular surface tissues

2.1 Evaluation of the impact of active transport in the corneal epithelium

3. Transporters in the blood-aqueous barrier

4. Transporters in neural retina

5. Transporters in the blood-retinal barrier

5.1 Evaluation of the impact of active transport in the blood-retinal barrier

6. Pharmacogenetics in ocular transporters

7. Conclusions 


\section{Introduction}

Drug delivery is a challenge in the treatment of many ocular diseases. Drugs should reach the target site at concentrations that are effective, while maintaining the drug concentration at nontoxic levels in off-target tissues in the eye and elsewhere in the body. Topical administration is by far the most common way to treat ophthalmic diseases, even though the ocular bioavailability of topically applied drugs is generally less than $5 \%$ ([1]. The low bioavailability is partly explained by the fast removal of the drug from the surface of the eye, but it is also affected by the low permeability of the cornea [1-3]. Still, topical administration can be used to deliver small molecular drugs at sufficient levels to treat diseases in the anterior parts of the eye (cornea, anterior chamber and iris). In contrast, drug delivery to the posterior tissues (retina, choroid, vitreous) by topical administration is not feasible, because the drugs do not distribute easily from the anterior parts to the back of the eye [4]. Systemic delivery of drugs to the posterior eye tissues is limited by the blood-ocular barriers that protect the sensitive ocular tissues [1]. However, the ocular barriers are not completely impermeable as lipophilic small molecules are able to cross these barriers [5]. Additionally, many hydrophilic endogenous compounds can cross those barriers with the help of transport proteins. For instance, nutrients like glucose and amino acids are supplied to the posterior ocular tissues through these barriers by active transport, similarly as in the blood-brain barrier. Active transport is also utilized in removal of metabolites from the eye to the blood circulation. However, the impact of ocular transporters on drug disposition is still not well understood, even though transporters are known to have an important role in the disposition of many drugs and their metabolites elsewhere in the body [6]. In principle, the involvement of transporters in drug disposition may lead to nonlinear pharmacokinetics, drug-drug interactions as well as inter-individual variability. Thus, transporters may alter the safety and efficacy of drugs and therefore, an evaluation of the interactions of new drug molecules with selected transporters is required during drug development $[7,8]$.

Transport proteins can be divided into two major families: the solute carrier (SLC) family and the ATP-binding cassette (ABC) family. The SLC transporters utilize facilitated diffusion or they couple an ion or electrochemical gradient to the transfer of their substrates across the cell membrane [9]. $A B C$ transporters, on the other hand, use ATP as the energy source to drive the transport. The human ABC transporter family consists of 48 members divided into seven subfamilies, whereas the human SLC family is considerably larger with 52 subfamilies, comprising over 430 transporters in total [10]. Only a few of these transporters are known to transport drugs. Among the $A B C$ transporters, members from the $A B C B, A B C C$ and $A B C G$ subfamilies efflux a wide variety of drugs and drug metabolites out from cells. The most widely studied $A B C$ drug transporter is $A B C B 1$, known as the multidrug resistance protein 1 (MDR1) or p-glycoprotein. Also, some other $A B C$ transporters are involved in translocating a wide variety of drugs. These include multidrug resistance associated proteins (MRPs) (members of the $A B C C$ subfamily) and the breast cancer resistance protein (BCRP) (ABCG2). As their names indicate, these transporters have been associated to drug resistance in cancer cells, where they are often overexpressed. However, these transporters are also widely expressed in healthy tissues, such as enterocytes lining the intestine, in canalicular cell membranes of the liver and proximal tubules of the kidney [6]. Depending on localization of transporters in these polarized cells, they may affect drug disposition by removing drugs and their metabolites from the cells into the intestinal lumen, bile or urine or alternatively to the blood circulation. Additionally, both MDR1 and BCRP are expressed in the capillary endothelium of the blood-brain barrier, where they efficiently prevent drug entry into the brain. 
The most notable drug transporters within the SLC family include the organic anion transporting polypeptides (OATPs, SLCO family), organic anion transporters and organic cation transporters (OATs and OCTs, both belonging to the SLC22A family) [6]. In contrast to the human ABC transporters, which are all efflux transporters, the SLC proteins primarily assist the cellular uptake of drugs. Members of these subfamilies can be found in many epithelia, even though some transporters are expressed only in a specific cell type. For instance, OATP1B1 and OATP1B3 have been found only on the basolateral membrane of hepatocytes, where they extract their substrate drugs from the blood circulation to the liver [11]. The OCTs generally transport cations, while small, hydrophilic anions are substrates of OAT and larger, more hydrophobic anions are transported by OATPs.

There is considerable overlap in the substrate specificity of transporters, both between members within the subfamilies as well as between efflux and influx transporters. Due to the substrate overlap and to the lack of specific substrates and inhibitors, the activity of a specific transporter is difficult to assess in vivo. In addition, when evaluating the impact of transporter activity, it is important to consider the passive membrane permeability of the substrate, as the total permeation depends on both the passive diffusion and the active transport $[12,13]$. The passive diffusion is determined by the physicochemical properties of the drug, while the active transport depends both on the substrate affinity and transport rate, as well as the expression levels of the transporter at the barrier. The active transport (in either direction) may not significantly affect the total permeability of compounds that show high passive permeability, while the active transport can be responsible for most of drug permeation if the compound has limited passive diffusion through cellular barriers.

The effect of transporter activity on ocular drug disposition is not well understood, even though ocular transporter expression has been the subject of numerous studies. We have collected and critically reviewed the literature to include only robust and well-performed studies on ocular expression and function of transporters that are known to affect drug disposition. Many contradictory reports can be found in the scientific literature and problems arise in comparing the expression and impact of the transporters due to the diverse array of methods that have been used. Most of the early expression data comes from studies on the mRNA expression, which does not necessarily correlate with the protein levels [14]. In this review, we focus on the ocular transporters with evidence on expression at protein level. Quantitative information of the ocular transporter expression is mostly missing, even though this would be required to assess the pharmacokinetic impact of active transport. The expression levels can be used to scale the in vitro cellular transporter activity to in vivo situation, which in many cases is practically impossible to quantitate. Quantitative proteomic analysis of transporters using liquid chromatography combined to mass spectrometry provides a huge promise for determining protein expression levels [15]. It is important also to realize that transporter expression may differ in cultured cells compared to the in vivo situation, especially in the case of continuous cell lines [16]. Therefore, we have included data mainly from ocular tissues, but also from ocular primary cells or differentiated stem cells when tissue expression data is scarce. Data from continuous and transformed ocular cell lines was not included in the review.

Finally, it should be noted that almost all studies on ocular drug pharmacokinetics are done in animals, mainly in rabbits and rodents, but the transporter expression and substrate recognition may differ between species. When assessing species differences, it is important to realize that many studies use antibodies that are raised against human transporters, and therefore they may not correctly recognize orthologues in other species. The 
species differences in transporter expression and function and their implications on the translation to human pharmacokinetics will be examined in this review. In order to distinguish between transporters in human and animal species, human transporters are abbreviated in capital letters, while other transporters from other species are abbreviated in lower case letters. Overall, literature on ocular transporters is confounded by many factors. Therefore, caution is needed to draw solid conclusions in this field. We have tried to examine the literature critically in order to present a realistic view on the expression and pharmacokinetic importance of ocular transporters.

\section{Transporters in ocular surface tissues}

The cornea is a transparent tissue that covers the iris, pupil and the anterior chamber (Figure 1). The cornea consists of five layers, of which the corneal endothelium, a cellular monolayer, is the innermost. The three middle layers; Bowman's layer, the stroma and Descemet's membrane are mainly acellular collagenous matrices, with sparsely distributed keratinocytes in the stroma. The corneal endothelium regulates the fluid and solute transport between the stroma and the anterior chamber. The corneal epithelium is the outermost layer consisting of approximately six layers of epithelial cells that form tight junctions between the apical cells. The corneal epithelium is the main barrier that restricts the permeability of topically administered drugs to the anterior chamber [17].

The conjunctival epithelium is located laterally from the corneal epithelium. In contrast to the cornea, the conjunctiva is a highly vascularized tissue. The conjunctiva covers the sclera of the eye (bulbar part) and lines the inside of the eyelids (palpebral part), where it produces mucus thus helping to lubricate the eye. The conjunctival epithelium is a thin stratified epithelium of 5-15 cell layers. Tight junctions exist on the outermost cell layers, but the conjunctiva is leakier than the cornea $[18,19]$. Due to the large surface area of the conjunctiva and its leakier epithelia, the major fraction of a topically applied drug dose permeates through the conjunctiva and enters the systemic blood circulation [20-22].

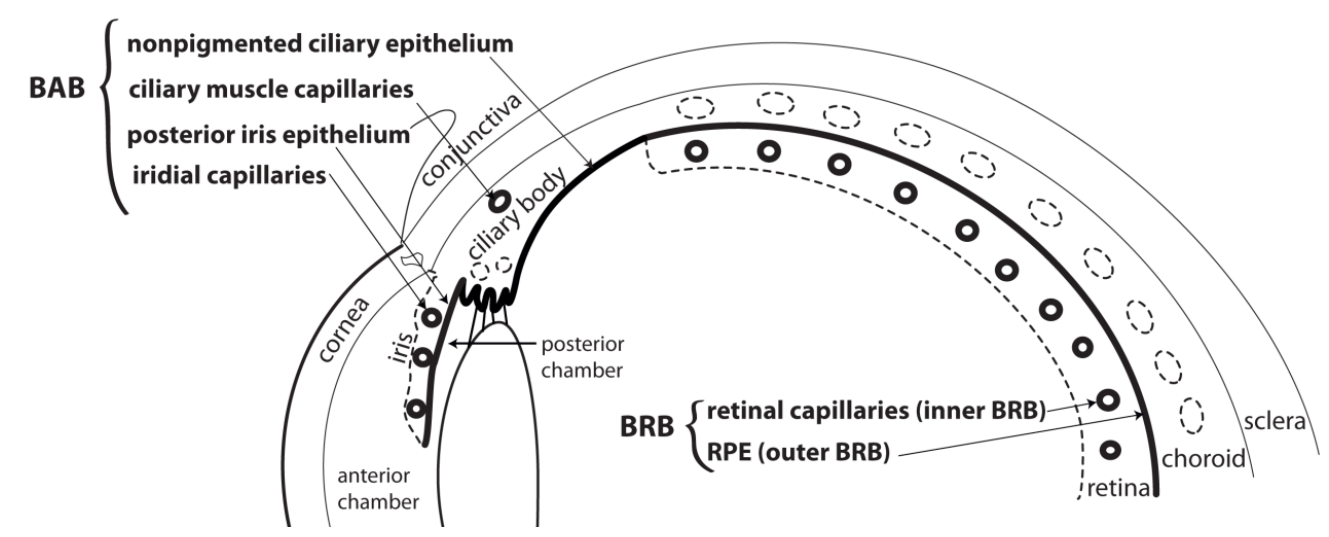

Figure 1. Schematic figure of the anatomy of the eye and the ocular barriers. Bold lines indicate tight barriers, while thin or dashed lines are leakier membranes.

Cornea. Overall, several drug transporters have been shown to be present in the corneal epithelium at protein level (Table 1). In contrast, information on the impact of corneal transporters on ocular drug delivery is sparse, but some in vivo or ex vivo studies, primarily in rabbits, have been reported. The transporters that are 
expressed and functional in the corneal epithelium are presented in figure 2. Among the efflux transporters, Mdr1 activity in rabbits has been well characterized. The impact of Mdr1 was reported in isolated rabbit cornea using rhodamine 123 as substrate [21]. A 2-3 fold higher permeability in the basolateral-to apical direction was observed compared to the apical-to-basolateral direction and the directionality was inhibited by verapamil, an Mdr1 inhibitor. The activity of Mdr1 was also studied in vivo using a single-dose infusion method, where a small well with Mdr1 substrate erythromycin was placed on top of the rabbit cornea [20]. The permeation of erythromycin through the cornea was determined by sampling the aqueous humor. The studied Mdr1 inhibitors (testosterone, cyclosporine, quinidine and verapamil) caused a 1.4-4 fold increase in the AUC value of erythromycin in the aqueous humor. Later, Hariharan et al. suggested that erythromycin is transported by both MDR1 and MRP2 in transfected MDCKII cells [23]. They used the same single-dose infusion method as Dey et al. [20], and confirmed that inhibition of Mrp2 or Mdr1 increased the AUC of erythromycin 2.5-4-fold in the aqueous humor. Erythromycin transport by Mrp2 has also been studied in isolated rabbit corneas [24]. Verapamil was included to inhibit Mdr1-mediated transport of erythromycin across the corneal samples, and the remaining efflux transport activity, which was attributed to Mrp2, was sensitive to MK571, an MRP inhibitor. Low Mrp1 and Mrp5 activity was observed in uptake assays with isolated rabbit cornea. In line with this, the AUC of acyclovir in aqueous humor increased 2.2 times in the presence of MK571 in rabbit after topical administration [25]. The authors proposed that the effect was due to Mrp5 inhibition, but the influence of Mrp2 cannot be ruled out, as acyclovir is an Mrp2 substrate and MK571 is an Mrp2 inhibitor. No activity was observed for either Mrp3 or Bcrp in rabbit corneas when methotrexate was used as a substrate, even though Mrp3 expression was detected in the cornea [21].

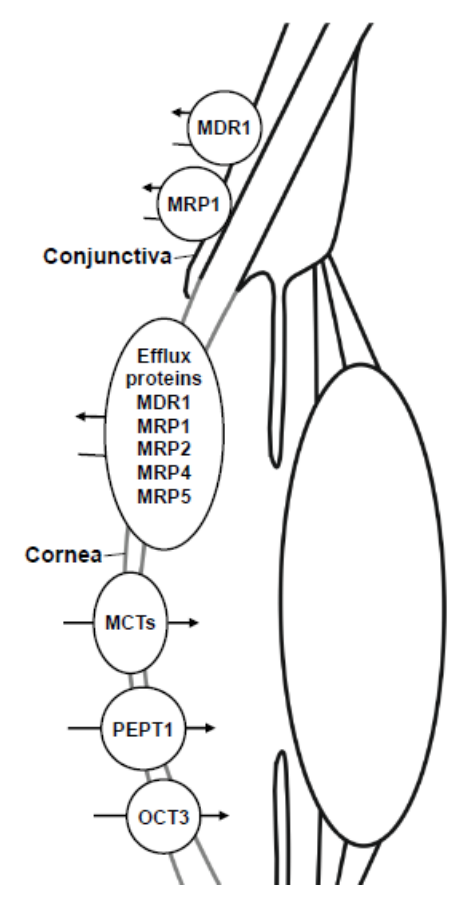

Figure 2. Schematic presentation of corneal and conjunctival transporters for which protein expression and functionality have been reported in tissues or in primary cells. Arrows indicate the direction of transport. For further information, see text, table 1 and table 2. 
Clearly, differences in efflux transporter expression exist between species (Table 1). For instance, Mdr1 is expressed and functional in rabbit corneal epithelium [21], but it is not present in human or porcine corneal epithelium $[21,26]$. Mrp4/MRP4 was detected in porcine, rat and human corneal epithelium, but not in rabbit corneal epithelium [16, 21, 27], while Bcrp/BCRP was found in human cornea, but not in rabbit, porcine or canine corneal epithelium [16, 21, 27, 28]. On the other hand Mrp1/MRP1, Mrp2/MRP2 and Mrp5/MRP5 are present in both human and rabbit corneal epithelium, and Mrp5 has also been detected in both porcine and rat cornea [16, 24, 29-31].

Only a few influx transporters have been subjected to functional studies in the cornea, even though expression of several transporters has been reported (Table 1). The organic cation transporters (Octs) were studied in rabbits in vivo [32]. Oct substrates, tetraethylammonium (TEA) or metformin were administered topically followed by closing of the eyelids after dosing. Quinidine and atropine, both of which are inhibitors of Oct, were administered 30 min prior to the substrates. The largest decrease in AUC in aqueous humor (2.4 fold) was observed for TEA in the presence of atropine. Currently, only OCT3 is known to be expressed at protein level in humans [27], but mRNA of both OCT1 and OCT2 have been detected in human cornea [33].

Benzoic acid permeability was found to be 12 times higher in the epithelium to endothelium direction than in the opposite direction in isolated rabbit corneas [34]. This directionality was reduced by a monocarboxylate drug, valproic acid, indicating that carrier-mediated transport for monocarboxylates exists in the rabbit cornea. The monocarboxylate transporters Mct1/MCT1 and Mct4/MCT4 have been detected in human and rabbit corneal epithelial cells. Active transport of amino acids (L-alanine, L-phenyl alanine and L-arginine) and nucleic acids has been demonstrated in isolated corneas, indicating existence of functional ASCT1, LAT1, B $(0,+)$-type amino acid transporter 1 and CNT3, respectively [35-38]. Prodrug technology has been investigated in order to improve drug absorption across the cornea by modifying the parent drugs to prodrugs that are influx substrates or able to bypass efflux transport. A 12 -fold increase in the AUC was observed when the amino acid and peptide transporters in the cornea were targeted for the delivery of the dipeptide ester prodrug of ganciclovir [39], while a 1.5-3-fold increase in the permeability was obtained for amino acid and dipeptide ester prodrugs of the MDR1 substrate quinidine [40]. The modest effect of the prodrug derivatization of quinidine may be explained by a minor contribution of the efflux on its parent drug or by the low capacity of peptide transport. Additionally, as the prodrugs have different physicochemical properties than the parent compound it is difficult to assess the true role of the active transport.

Conjunctiva. The expression and activity of transporters in the conjunctiva has received much less attention than the corneal transporters (Table 2). This is due to the dominant role of the cornea as a route of ocular drug absorption. The conjunctiva serves as a route in non-corneal drug absorption, but the drug distribution to inner ocular tissues after conjunctival permeation is limited by the extensive drug clearance to the blood circulation [41]. On the contrary, trans-corneal permeation results in almost unrestricted drug distribution to the anterior ocular tissues (e.g. trabecular meshwork, iris, ciliary body). Therefore, corneal transporters may have bigger therapeutic impact.

The expression of Mdr1 has been confirmed in rabbits on the apical side of excised conjunctiva as well as in the primary cells of the conjunctiva $[42,43]$. The Mdr1 substrates cyclosporine A, verapamil and propranolol showed 2-9-fold higher transport in the basolateral-to-apical than opposite direction in primary cells of rabbit 
conjunctiva. In addition, transport of both cyclosporine A and propranolol was inhibited by other Mdr1 substrates (verapamil, progesterone) in a dose-dependent manner [42, 43]. Another efflux transporter, Mrp1, was localized to the basolateral side of the rabbit conjunctival epithelium both in primary epithelial cells and excised conjunctiva [44]. The transport of leukotriene C4 across cultured rabbit conjunctival epithelial cells showed a slightly preferred apical-to-basolateral transport with a ratio of 1.4 , and the directionality of leukotriene C4 was abolished in the presence of the MRP inhibitor probenecid.

The functionality of the Oct influx transporters has been verified in rabbit primary conjunctival cells [45]. Transport of the Oct substrates guanidine and TEA was 5- or 50-fold higher, respectively, in the apical-tobasolateral direction, indicating that Oct transporters are expressed on the apical side of the epithelial cells of the rabbit conjunctiva. Amino acid and dipeptide transporters are also present in the conjunctival epithelium. Active uptake of L-carnosine was observed in primary cultured conjunctival rabbit epithelial cells, with a 5-fold higher uptake from the apical side of the cells, but the protein that was responsible for the transport was not identified [46].

\subsection{Evaluation of the impact of active transport in the corneal epithelium}

Expression and activity of several transporters has been verified on the ocular surface, especially the cornea (Table 1, Figure 2). However, even though a transporter protein is expressed at the corneal epithelium, it does not necessarily have a significant pharmacokinetic impact on drug absorption. It is important to note that the experimental set up in the in vivo trans-corneal infusion studies may overestimate the impact of the active transport, since the drug is usually allowed to permeate at least for an hour, while topically applied drugs are removed from the ocular surface in a few minutes. Similarly, when the permeability across isolated corneas is determined, the incubation time is usually much longer than the interaction time in topical administration, potentially leading to misinterpretations of the significance of active transport.

The impact of active transport depends on several factors, such as the affinity towards the drug substrate $\left(\mathrm{K}_{\mathrm{m}}\right)$, drug concentration, rate of passive drug permeation, and expression level of the transporter protein. In order to understand the impact of these factors we carried out simulations on the corneal drug absorption to the anterior chamber with STELLA simulation software (version 10.0.3, isee systems, Lebanon, NH, United States). We assumed a typical drug dose $(25 \mu$ leye drop solution with a drug concentration of $1 \%)$ and range of passive permeability (from $5 \times 10^{-7} \mathrm{~cm} / \mathrm{s}$ to $\left.5 \times 10^{-5} \mathrm{~cm} / \mathrm{s}\right), V_{\max }$ values $\left(0.001-5 \mu \mathrm{g} / \mathrm{min}\right.$ ) and $\mathrm{K}_{\mathrm{m}}$ values $(0.1-1000 \mu \mathrm{g} / \mathrm{ml}$, corresponding to approximately 0.25 - $2500 \mu \mathrm{M}$ with 400 Da compounds, estimated based on the UCSF-FDA TransPortal Database, http://transportal.compbio.ucsf.edu). Realistic fixed values were used for intraocular pharmacokinetic parameters (for full model description, see supplementary material). Apical influx transport to the corneal epithelium (model 1) and apical efflux transport from the corneal epithelium (model 2) were simulated (Figure 3). 


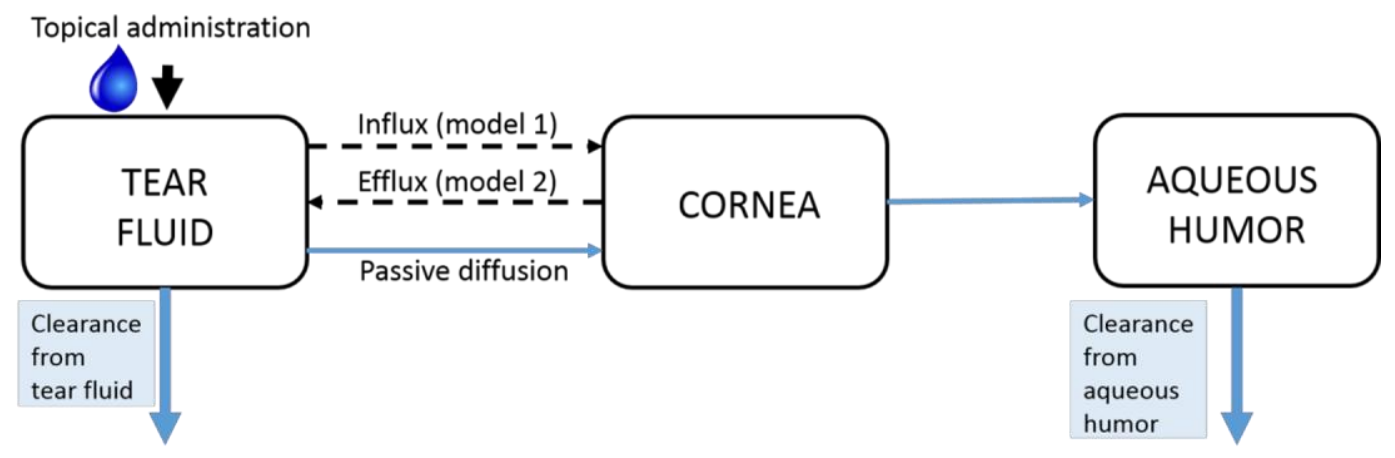

Figure 3. Schematic presentation of the corneal simulation models. The eye drop is instilled into tear fluid and active transport at the corneal epithelium either increase (influx, model 1) or restrict (efflux, model 2) absorption into the aqueous humor.

The clinical significance of the active transport can be estimated based on drug exposure (AUC) to the aqueous humor. The simulations were performed to identify the parameter combinations that cause a significant increase in the simulated AUC values compared to purely passive drug absorption. A difference that causes over 5-fold increase in AUC is considered significant, while a 2-5 fold change only leads to a minor effect and less than 2 -fold differences are not deemed significant. The rate of both passive and active transport $\left(\mathrm{V}_{\max }\right)$ affect the impact of active transport on drug exposure in the aqueous humor. Based on the simulations, active influx does not reach over 5 -fold increase of the AUC values in the aqueous humor if the passive permeability is high $\left(5 \times 10^{-6}\right.$ or $\left.5 \times 10^{-5} \mathrm{~cm} / \mathrm{s}\right)$, even when the $V_{\max }$ of the influx is at the highest simulated level $(5 \mu \mathrm{g} / \mathrm{min})$ (model 1 , Figure $4 A-C)$. In corneal permeability experiments, $V_{\max }$ values between $0.001-2 \mu \mathrm{g} / \mathrm{min}$ have been observed for influx transporters $[23,35,47]$. At low passive permeability $\left(5 \times 10^{-7} \mathrm{~cm} / \mathrm{s}\right)$, influx transport has a significant effect on the drug exposure in the aqueous humor, when the $V_{\max }$ is $1 \mu \mathrm{g} / \mathrm{min}$ or higher (Figure $4 \mathrm{~A}-\mathrm{C}$ ). However, it should be noted that topically applied ophthalmic drugs rarely have a very low passive permeability, indicating that the overall influence of active transport in corneal absorption may be minor [48].

A suitable $V_{\max }$ range for efflux transporters is difficult to estimate, since there are no corneal permeability reports available with quantitated rates for efflux transport. Still, a similar increase in the AUC of the aqueous humor as for the influx transporters could be achieved by using a 50 -fold smaller $V_{\max }$ value $(0.1 \mu \mathrm{g} / \mathrm{min})$ when the $K_{m}$ was set to $0.1 \mu \mathrm{g} / \mathrm{ml}$ (Figure 4D). However, when the substrate affinity for efflux transporters is low $(1000 \mathrm{\mu g} / \mathrm{ml}$, Figure $4 \mathrm{~F})$, the impact of active transport becomes minimal regardless of other tested parameters. The efflux model is much more sensitive to changes in the $K_{m}$ values than the influx model, which can be explained logically. In the efflux model the transport rate depends on the drug concentration in the corneal epithelium, but in the influx model the rate depends on the concentration in the tear fluid. The drug concentration in the tear fluid is very high at the time of administration and then swiftly decreases due to the rapid clearance from the surface of the eye, while the drug concentration in the corneal epithelium is initially much lower and declines slowly. This is also reflected in the obtained results from simulating the impact of the dose on the active transport. The drug concentration in eye drops is usually between $0.1-1 \%$. In simulations with the influx model, a $0.1 \%$ dose had 3-6 fold larger impact on the AUC value compared to the $1 \%$ dose, when passive permeability was low and $V_{\max }$ high (data not shown). In the efflux model the effect of a lower dose was even larger, also at lower $V_{\max }$, but only when the affinity for the transporter was high. 
We did not include back diffusion from the corneal epithelium into the lacrimal fluid to our simulation model, because the presence of the drug in the tear fluid, and period of drug absorption is short thereby minimizing the impact of back diffusion in the case influx transport. Also, reliable inclusion of this factor is complicated due to the unusual kinetic scheme (rapid kinetics in the tear fluid, partitioning and depot formation in the epithelium). Simplified inclusion of back diffusion showed only minimal effects and this factor does not have influence on our conclusions in Figure 4.

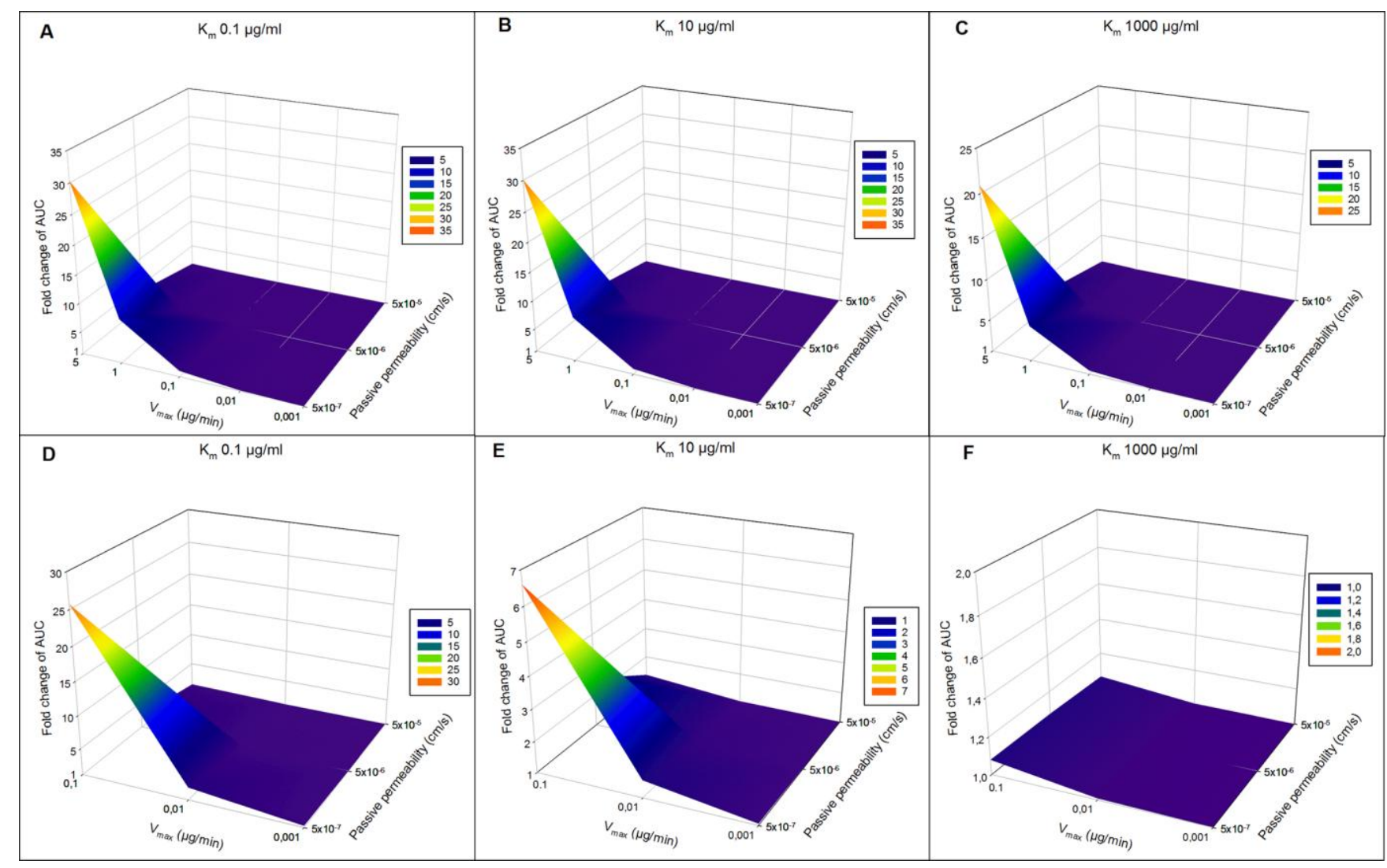

Figure 4. Simulations on the effect of corneal influx (A-C) and efflux (D-F) on drug absorption after topical administration of $1 \%$ eye drop. Fold change in the $A \cup C\left(A \cup C_{\text {passive }} / A \cup C_{\text {active }}\right)$ is shown by the color range. The $A \cup C$ in aqueous humour was simulated with $K_{m}$ values of $0.1 \mu \mathrm{g} / \mathrm{ml}(A, D), 10 \mu \mathrm{g} / \mathrm{ml}(B, E)$ and $1000 \mu \mathrm{g} / \mathrm{ml}(C, F)$.

Overall, the clinical significance of active transport on corneal drug permeability in vivo appears to be quite low and apparent only at specific parameter combinations. The conclusion is additionally supported by quantitative structure-property relationship (QSPR) modelling of passive corneal and conjunctival permeability, where predictive models did not yield significant outliers among the tested compounds that would indicate active transport $[48,49]$. However, the impact can be substantial for drugs with low passive permeability and a high active transport rate as indicated by the pharmacokinetic simulations. The aforementioned principles determine the impact of active transport on drug delivery after administration of pharmaceutical suspensions or controlled release devices, but in these cases only the dissolved or released drug is subject to the active transport. Concentration of the dissolved or released drug is typically lower than the levels after instillation of a drug solution. Theoretically, relative importance of active transport is more pronounced at low drug concentrations, but it will be dependent on multiple factors as described above. 


\section{Transporters in the blood-aqueous barrier}

The blood-aqueous barrier (BAB) is located in the iris-ciliary body and it is composed of the capillary endothelium of the iris and the ciliary muscle vessels, and the epithelial cell layers of the ciliary body (nonpigmented epithelial cell layer, NPE) and the posterior iris (Figure 1) [50-52]. The epithelium of the ciliary body is a cellular bilayer that also comprises the pigmented epithelial (PE) cell layer in addition to NPE. The apical membranes of the NPE and PE cells face each other and are connected by gap junctions. The ciliary body is highly vascularized, but unlike the tight capillaries in the iris and the ciliary muscle, the choroidal capillaries in the ciliary body are fenestrated and leaky.

Efflux transporters (MDR1, MRPs) at the apical membrane of the NPE cell layer have been proposed to participate in maintaining the ocular barrier [30]. They would prevent drugs and other xenobiotics that diffuse from the fenestrated ciliary capillaries from permeating the NPE cell layer by actively pumping the compounds back into the space between the PE and NPE cells. In addition, hydrophilic compounds could be taken up from the aqueous or vitreous humor and transported across the NPE layer as the cooperation of basolateral uptake transporters and apical efflux transporters.

The $\mathrm{BAB}$ expresses several efflux and influx transporters (Table 3, Figure 5B). In vivo studies on transporter function in the $B A B$ are complicated by the difficulty of separating the impact of the blood-retinal barrier (BRB) and even the corneal barriers in some cases [53]. Still, there are several reports supporting MDR1 activity in the BAB [54-56]. In rabbits, the aqueous humour distribution of intravenously administered rhodamine 123 was markedly increased by topical administration of the Mdr1 inhibitor quinidine in a dose dependent manner [55]. More recently, Fujii et al. studied the role of Mdr1 in the BRB, BAB and blood-brain barrier (BBB) using mdr1a knockout rats [54]. All studied Mdr1 substrates (quinidine, verapamil and digoxin) had lower aqueous humour and brain uptake index values (AHUI, BUI, respectively) in wild-type rats than predicted based on the lipophilicity of the compounds, whereas in Mdr1a knockout rats, AHUI and BUI values were closer to predicted

values. For instance, $\mathrm{K}_{\mathrm{in} \text {,aqueoushumor }}$ for verapamil that was determined from Mdr1a knockout rats was three-fold higher than that obtained from wild-type rats. The contribution of Mdr1 efflux of verapamil, calculated as the ratio of $\mathrm{K}_{\text {in }}$ between wild-type and Mdr1a knockout rats, was $66.1 \%$ for the $\mathrm{BAB}$. In contrast, the contribution of Mdr1 for the BRB and BBB, were $3.0 \%$ and $91.9 \%$, respectively. These results suggest that in rats, the impact of Mdr1 on the permeability of verapamil at the BAB is higher than in the BRB, but lower than in the BBB [54]. Importantly, as most substrates, including verapamil, are recognized by several transporters, the apparent impact on permeability might arise from interaction with multiple transporters. Interestingly, in Mdr1a knockout rats, the AHUI of digoxin, and also quinidine and verapamil to a lesser extent, was decreased by Mdr1 inhibitors, which indicates that unidentified carrier mediated influx transporters exist for these substrates in the blood-ocular barriers at least in rodents [54]. Digoxin has been suggested to be transported to the brain via Oatp1a4 [57] and Oatp1a5 [58], which are rodent orthologues of the human OATP1A2 transporter. OATP1A2, as well as Oatp1a4, but not Oatp1a5, have been found at the basolateral membrane of the NPE [59].

In addition to in vivo studies, there is substantial ex vivo and in vitro evidence of transporter activity in the BAB. Already in 1994, Kondo and Araie observed a three-fold higher transport of carboxyfluorescein in the aqueous humor to stroma direction across isolated iris-ciliary bodies of albino rabbits [60]. Later, Mrp2 activity was found in porcine primary NPE cells, where several Mrp2 substrates displayed increased intracellular 
accumulation in the presence of MK571, an Mrp inhibitor. Recently, the active transport of organic anions was examined using bovine ciliary body sections mounted in Ussing chambers and a perfused eye preparation [61]. The transport of several marker substrates was followed; p-aminohippurate (a substrate of Mrp2, Mrp4 and Oat1), estrone-3-sulfate (Oat3, Bcrp, Mrp) and 6-carboxyfluorescein (Oat1, Oat3 and Mrps). Up to five-fold higher transport was measured for $\mathrm{p}$-aminohippurate and estrone-3-sulfate in the aqueous humor-to-blood direction than in the opposite direction across excised ciliary body. Oat inhibitors, probenicid and novobiocin, were added to the aqueous humour side of the tissue, while the Mrp inhibitor, MK571, was added from the opposite side to match the expression of the Oat and Mrp target transporters at the basolateral and apical sides of the NPE cells. The inhibitors reduced the net active transport either completely (probenecid and novobiocin) or partially (MK571), indicating that Mrp and Oat transporters are indeed active at the BAB. The elimination of 6-carboxyfluorescein from the aqueous humor was measured ex vivo in a perfused bovine eye. The amount of the marker was 4.8-fold reduced in the venous perfusate when novobiocin was added to the aqueous humor [61]. 


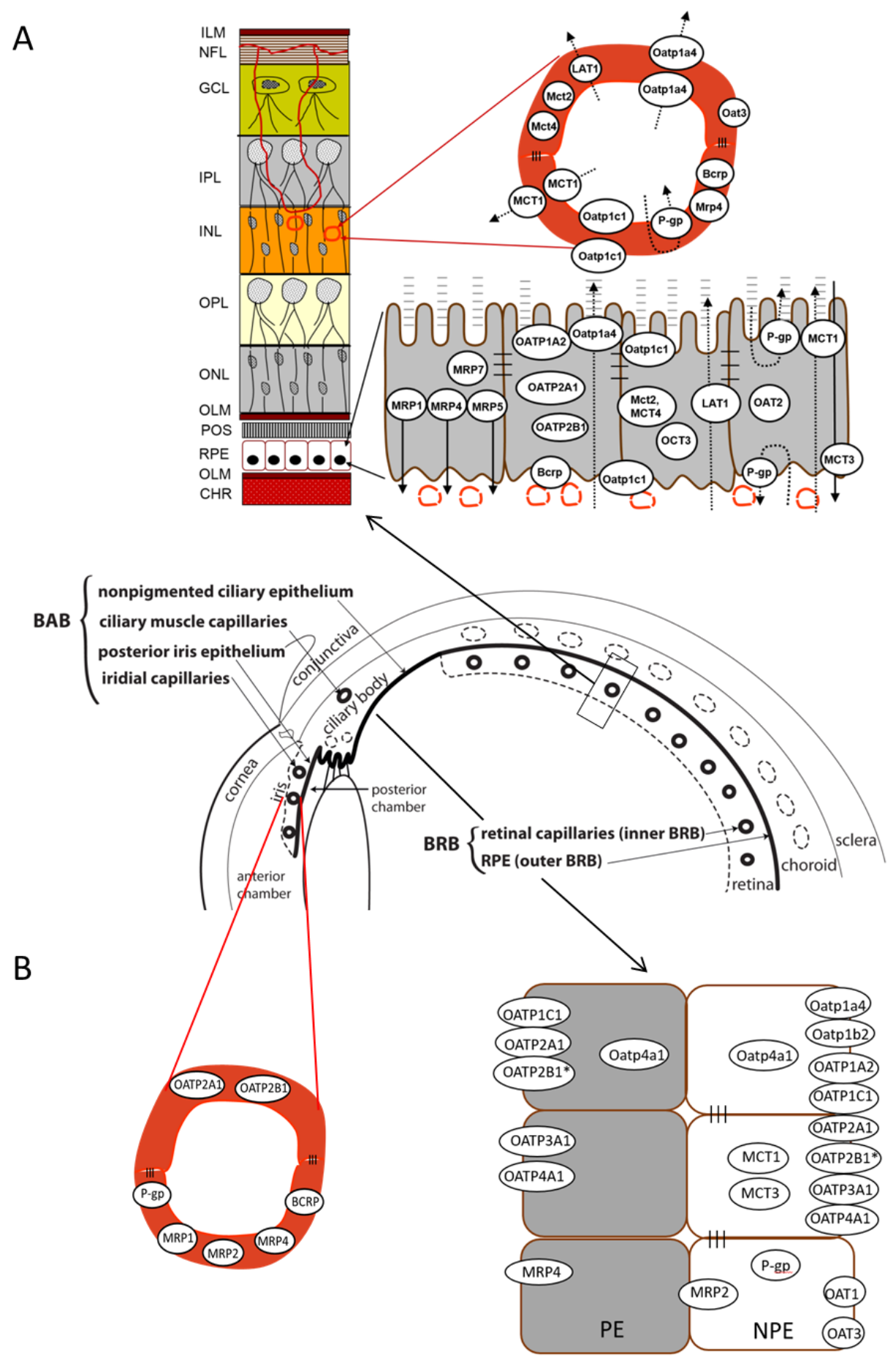

Figure 5. Transporter expression at ocular barriers. A) Expressed transporters and localization of drug transporters at the BRB. ILM, inner limiting membrane; NFL, nerve fiber layer; GCL, ganglion cell layer; IPL, inner plexiform layer; INL, inner nuclear layer; OPL, outer plexiform layer; ONL, outer nuclear layer; OLM, outer limiting membrane; POS, photoreceptors; $\mathrm{RPE}$, retinal pigment epithelium; CHR, choroid. Arrows indicate the direction of transport, and dotted lines indicate that the activity could not be distinguished between inner and outer BRB. Transporters for which the localization to either the apical or basolateral membrane is not determined are placed intracellularly. B) Expressed transporters and localization at 
the BAB. Transporters for which the localization to either the apical or basolateral membrane is not determined are placed intracellularly. NPE, non-pigmented epithelium and PE, pigmented epithelium.

\section{Transporters in the neural retina}

The neural retina is the light-sensitive tissue in the posterior part of the eye that converts absorbed light to nerve impulses that are sent to the brain. It contains multiple layers, from the photoreceptors lining the retinal pigment epithelium to the inner limiting membrane facing the vitreous (Figure 5A). The neural retina is not considered to limit the diffusion of small molecular weight drugs in the eye, but it is a potentially important target for ocular drugs. Transporters may affect the accumulation of drugs in the target cells of the neural retina (e.g. photoreceptor and ganglion cells), efflux transporters by reducing the accumulation, while influx transporters could potentially be targeted for drug delivery.

Currently, there is not much known regarding the expression of efflux transporters in the neural retina. In humans, BCRP was identified in the nerve fiber layer, while MRP1 and MRP5 could not be detected in the neural retina [27]. Uptake transporters that could potentially affect the accumulation of drugs in the cells have been detected in many cell types in the neural retina. The expression of the organic anion transporters OATP1A2, OATP1B3 and OATP2B1 and the organic cation transporter OCT3 was studied in human tissues by immunohistochemistry $[27,62]$. OCT3 is expressed in the photoreceptors and OATP1A2 was found both in the plasma membrane of photoreceptor bodies in the outer nuclear layer and in the inner nuclear layer where it is most likely expressed in the soma of amacrine cells, as well as in the ganglion cell layer. OATP1B3 was not detected, but OATP2B1 was localized to the proximal processes of amacrine cells in the innermost part of the inner nuclear layer and to the neuronal processes in the inner plexiform layer. In rats, two OATP1A2 orthologues, Oatp1a4 and Oatp1a5, were detected in the inner nuclear layer and ganglion cells and the inner plexiform and ganglion cell layers, respectively [63]. The amino acid transporter LAT1 has a similar localization in the neural retina of rats; it is expressed in neural cells in the ganglion and inner nuclear cell layer [64]. In addition, the expression of monocarboxylate transporters has been reported in the neural retina of rats. Mct1 was localized to Muller cell microvilli and photoreceptor inner segments [65-67] and Mct2 was not found at all in the neural retina by Bergelsen et al [67], while it was localized to the inner and outer plexiform layers in other studies [65-67].

\section{Transporters in the blood-retinal barrier}

The BRB limits the distribution of drugs from blood circulation to the posterior tissues of the eye, effectively restricting the use of systemic drug administration for treatment of these tissues. The BRB consists of the retinal pigment epithelium (RPE) that forms the outer BRB and the endothelium of the retinal capillaries in the inner BRB. The RPE is a pigmented monolayer that maintains the homeostasis of the neural retina. The barrier function in the RPE and in the endothelial cells of the capillaries is supported by tight junctions, similarly to capillaries in the BBB. Some species, e.g. rabbits and horses, do not have retinal vasculature, and therefore only possess the outer BRB [68]. 
Several efflux transporters in the BRB (Table 4, Figure 5A) may contribute to its barrier function. On the other hand, basolateral influx transporters could enhance the uptake of substrate drugs from the systemic circulation, and might be targeted to deliver drugs to treat retinal diseases. The reports on MDR1 expression in the BRB are conflicting; expression on both apical and basolateral membranes of human RPE tissue was reported by Kennedy et al. 2002, while the protein remained below the detection limit in primary human fetal RPE cells in our recent quantitative proteomics study [69]. Species differences may exist, as the expression of Mdr1 protein was localized to the inner BRB rather than the RPE in a recent rodent study [70]. Numerous studies on rodents $[54,56,70,71]$, rabbit $[72,73]$ and porcine Mdr1 [74] have investigated the activity of Mdr1 in the BRB. The effect of Mdr1 in these studies is generally low, with the increase in retinal uptake ranging from none to 3.5-fold in knock-out animals or after Mdr1 inhibition. Recently, a human study was published utilizing PET scans to determine the ocular uptake of verapamil, an MDR1 substrate [75]. Taken together, MDR1 can have a statistically significant effect on the transport across the BRB, but the clinical significance is low and the inhibition of MDR1 has lesser effect on the retinal distribution than the brain distribution both in rodents and humans $[54,56,70,71,75]$.

Bcrp does not appear to have a high clinical significance for ocular drug distribution, as Bcrp knockout mice or Bcrp inhibition did not result in increased entry rate of a studied Bcrp substrate, mitoxantrone [70]. The expression pattern of BCRP in the BRB is still unclear. BCRP was not identified in cultured human fetal primary RPE cells, but there is convincing evidence for Bcrp expression in the inner BRB of mice (Table 4).

The presence of MRPs in the BRB is beyond doubt, but there are conflicting reports on expression of specific MRPs. Most reports have identified MRP1, MRP4, MRP5 and MRP7 at the BRB, while the expression of MRP2, MRP3 and MRP6 is more unclear (Table 4). However, the studies have been performed with tissues or cells from several species and using different detection methods, which may explain some of the reported inconsistencies. The potential clinical significance of MRP activity is supported by the observed directionality in the blood-ocular permeability of fluorescein, which is a substrate of the MRPs. The permeability of fluorescein was about $10^{-5} \mathrm{~cm} / \mathrm{s}$ in the vitreous-to-blood direction, while it was only $10^{-7}-10^{-6} \mathrm{~cm} / \mathrm{s}$ in the opposite direction in monkeys and humans [76-78]. In line with these early studies, fluorescein displayed 11.3-fold higher permeability in the retina-to-choroid direction across isolated porcine RPE tissue sheets [74]. When the MRP inhibitor probenecid was added, the permeability difference was equalized, indicating expression of Mrp transporters on the choroidal side of the RPE. However, it should be noted that both MRPs and OATs transport fluorescein and are inhibited by probenecid, and therefore all observed activity cannot be attributed to the MRPs without further studies. Added evidence for Mrp basal membrane expression and activity at the outer BRB of mice was recently presented [70]. Inhibition by a broad-spectrum MRP inhibitor, MK571, increased the retinal entry of zidovudine. In contrast to Mdr1 and Bcrp, which seem to have a higher impact on drug disposition at the BBB, Mrp was evaluated to be similarly involved at both the BRB and the BBB [70].

The activity of influx transport on drug permeability in the BRB is not as well established as the efflux activity, even though carrier-mediated uptake for several substrates has been identified. In vivo uptake of TEA and pravastatin has been reported in rabbits and rats, respectively, and for both substrates the ocular uptake after inhibition was decreased to approximately half of the control $[56,79]$. The active transport was suggested to be mediated by Oct and Oatp1a4 (a rodent orthologue of human OATP1A2), respectively. OATP1A2 is expressed in human RPE, but there is only evidence for OCT3 expression in the human oBRB [27,69]. Similarly, active uptake 
for L-leucine, L-carnitine and nicotinate has been attributed to LAT-1, MCT1 and OCTN2, respectively [64, 80, 81].

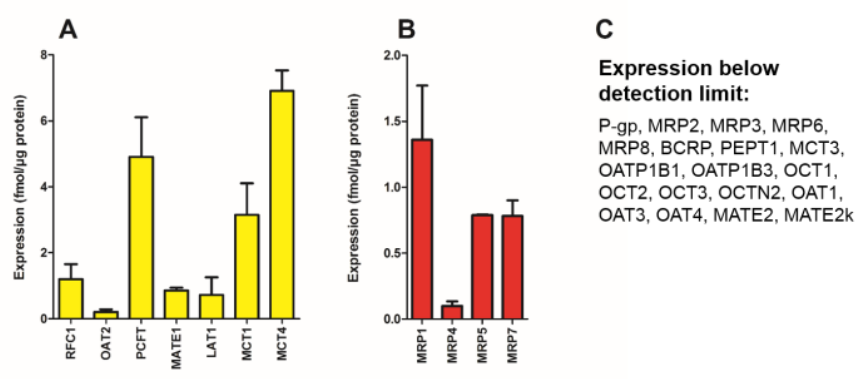

Figure 6. Quantitative transporter expression in human fetal RPE cells. A) Influx transporters, B) efflux transporters and C) drug transporters whose expression was below the detection limit (data from [69]).

Recently, we quantitated several ABC- and SLC transporters in the plasma membranes of human fetal RPE cells (Figure 6, [82]). These proteins included several transporters for nutrients and amino acids, lactate and drugs. Many influx transporters with known drug substrates remained below the detection limit, however, multidrug and toxin extrusion protein 1 (MATE1, SLC47A1), OAT2 and folate transporters reduced folate carrier 1 (RFC1, SLC19A1) and the proton-coupled folate transporter (PCFT, SLC46A1) were quantitated (Figure 6A). Among ABC transporters, MRP1 displayed the highest expression (Figure 5B). In addition, MRP4, MRP5 and MRP7 were expressed above quantitation limits, whereas MRP2, MRP3, MRP6, MRP8 expression remained below the detection limit. MDR1 and BCRP also remained below the detection limit, supporting the previous conclusions that MRP's are mainly responsible for the active efflux in the RPE cells. PCFT and the lactate transporters MCT1 and MCT4 had the highest expression level of the transporters with known drug substrates (3-7 fmol/ $\mu \mathrm{g}$ total protein), while the other detected drug transporters had clearly lower expression levels $(<2 \mathrm{fmol} / \mu \mathrm{g}$ total protein).The LAT1, RFC1, MCT1 and MRP4 expression levels were similar as reported for human BBB microvessels, while the other transporters found here were below the detection limit in the brain. On the other hand, the expression level of the efflux transporters MDR1 and BCRP was much higher in the BBB (6 and 8 $\mathrm{fmol} / \mu \mathrm{g}$ protein, respectively) [83].

\subsection{Evaluation of the impact of active transport in the blood-retinal barrier}

Many known drug transporters are expressed at the BRB (Table 4, Figure 5A), but the clinical significance of their activity for drug distribution is not yet clear. In general it could be assumed that the transporters would have smaller impact on drug disposition after intravitreal administration, as the drug concentrations are relatively high and may saturate the active transport. On the other hand, the drug concentrations are much lower in the blood, and the transporters may have a larger influence on the permeability in the choroid-toretina direction. Unfortunately, only a few in vivo studies have been conducted, mostly in rodents, which 
usually describe the retinal uptake index after a single dose of transporter substrate and inhibitor. The animals are sacrificed very shortly after the injection, making it difficult to assess the clinical relevance, which ideally should be determined from the drug exposure, i.e. the AUC. The overlapping substrate and inhibitor specificities between transporters add another layer of uncertainty to the evaluation of the involvement of individual transporters. The expression levels of many transporters may also be too low to have a large influence on drug disposition, as suggested by quantitative proteomics studies [82][69](Pelkonen et al., 2017a)[69]. Furthermore, QSPR modeling of half-life or clearance of intravitreously administered drugs [84-86], did not reveal any clear outliers from passive diffusion driven clearance, indicating that active transport does not greatly influence the permeability of the drugs used in the studies.

Importantly, in addition to its barrier function, the RPE itself is a drug target. Efflux proteins expressed on the RPE surface may have significant impact on the RPE drug exposure, even if the impact on the overall drug distribution in the posterior eye segment would be small. We simulated the AUC in the RPE with several $\mathrm{K}_{\mathrm{m}}$ $(0.1-1000 \mu \mathrm{g} / \mathrm{ml}), V_{\max }(0.01-0.1 \mu \mathrm{g} / \mathrm{min})$ and $P_{\text {app }}\left(6 \times 10^{-6} \mathrm{~cm} / \mathrm{sec}-6 \times 10^{-4} \mathrm{~cm} / \mathrm{sec}\right)$ values using STELLA simulation software (version 10.0.03, isee systems, Lebanon, $\mathrm{NH}$, United States) to evaluate the influence of efflux proteins at the RPE on the tissue exposure. Systemic and intravitreal administration were simulated with two separate model structures (Figure 7), and both models were modified according to efflux localization either on the vitreal (apical) or choroidal (basolateral) side of the RPE. Model parameter values represent realistic values collected from the literature (for further information, see the supplementary material). In the case of $V_{\text {max }}$ only relatively small values were simulated $(0.01-0.1 \mu \mathrm{g} / \mathrm{min})$; however, even these levels were shown to alter the kinetics in the RPE.

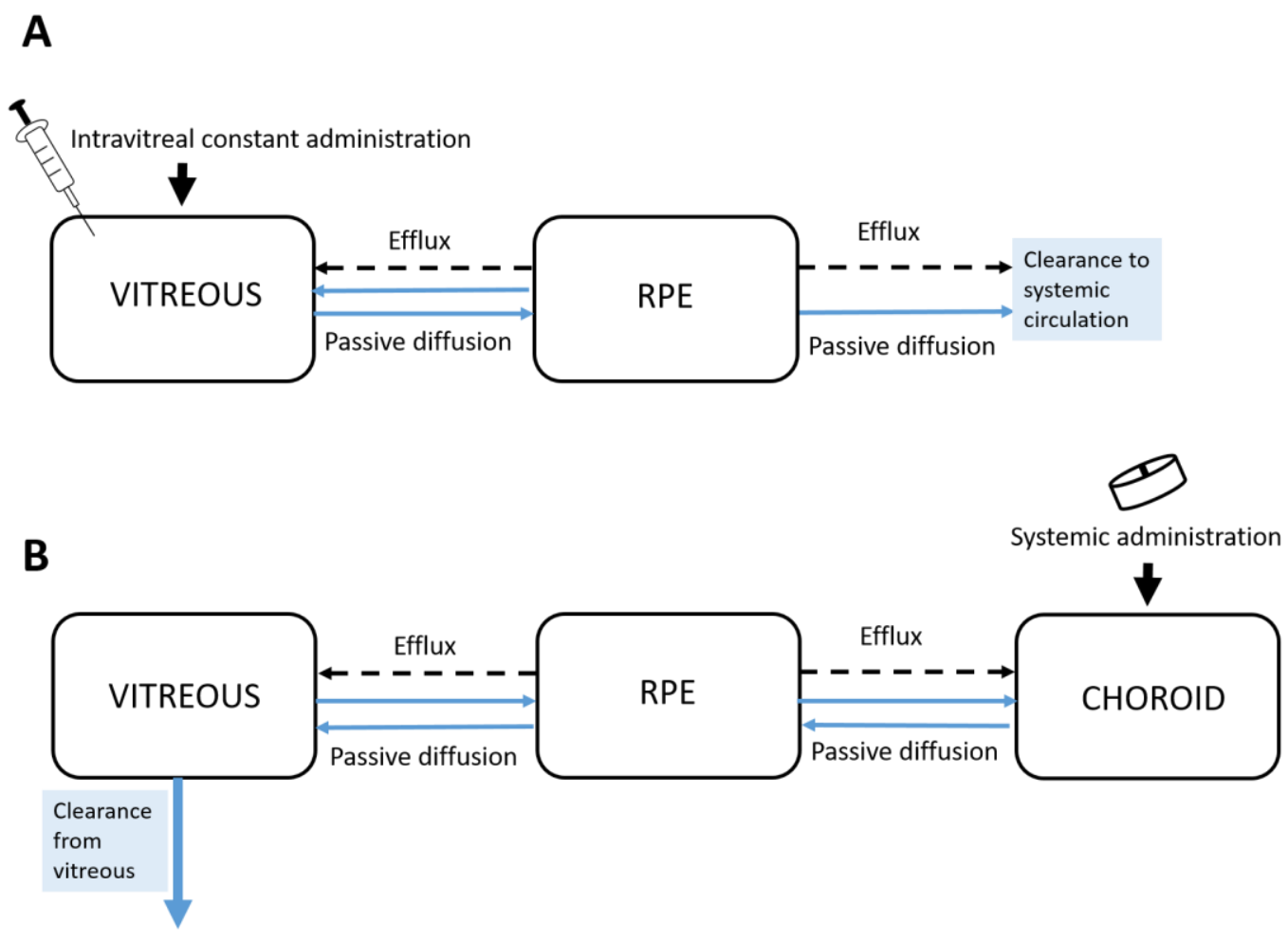


Figure 7. Schematic presentation of RPE simulation models. The drug is delivered to the RPE via intravitreal administration (A) or from the choroidal blood flow by systemic administration (B). Active transport (efflux out from the RPE) is localized either on the apical or basolateral side of the RPE. Both administration routes represent steady state concentrations in the vitreous (A) or in the systemic blood flow (B). Passive diffusion from the systemic blood flow to the RPE was not considered in the intravitreal administration model $(A)$ since the concentration in the systemic circulation is extremely low after intravitreal drug administration.

Our aim was to identify situations where the simulated AUC in the RPE with transport activity would show more than 5-fold increases over the situation without any active transport. In the case of intravitreal administration (Figure 8A), AUC was simulated only in the RPE compartment. Due to the model structure, the simulations result in similar AUC values regardless of the localization of the efflux transport to the apical or basolateral side of the RPE compartment. In the simulations, active transport did not significantly alter RPE drug exposure with any parameter combinations when using the highest simulated vitreal concentration (2500 $\mu \mathrm{g} / \mathrm{ml}$ ) or the highest $\mathrm{K}_{\mathrm{m}}$ values (Figure 8A-F). However, large changes were seen in the intracellular AUC of the RPE at lower vitreal concentrations and higher transporter affinity. The most dramatic differences (over 5000fold) resulted from simulations with low vitreal concentration, high affinity $\left(K_{m} 0.1 \mu \mathrm{g} / \mathrm{ml}\right)$ and the high $V_{\max }$ values $(0.1 \mu \mathrm{g} / \mathrm{min})$ combined with the lowest passive permeability value $\left(P_{\text {app }}=6 \times 10^{-6} \mathrm{~cm} / \mathrm{sec}\right)$ (Figure $8 \mathrm{~B}$ ). Our simulations with the systemic administration model (Figure 9) resulted in a comparable dramatic reduction (over 2000-fold difference) of the AUC in the RPE with the same parameter combinations (Figure 9B). Other parameter combinations resulted in more modest changes, but over 5 -fold differences could be observed at each permeability rate. As with the vitreous administration model, the simulations with systemic administration resulted in similar AUC values in the RPE regardless of on which side of the RPE the efflux is localized. In contrast, the AUC in the vitreous was not significantly altered when the efflux activity was localized to the apical side of the RPE, however, basolateral efflux reduced the AUC in the vitreous to similar extent as in the RPE (data not shown).

In general, for compounds with low affinity to efflux proteins $\left(K_{m}=1000 \mu \mathrm{g} / \mathrm{ml}\right.$, which corresponds to $2500 \mu \mathrm{M}$ of a $400 \mathrm{Da}$ compound), the active transport does not change the AUC profile. When $\mathrm{K}_{\mathrm{m}}$ decreases to 100 $\mu \mathrm{g} / \mathrm{ml}, \mathrm{AUC}$ is altered significantly in both models, but only when passive permeation is slow $\left(\mathrm{P}_{\text {app }} 6 \times 10^{-6}\right.$ $\mathrm{cm} / \mathrm{sec})$ and protein expression high $\left(\mathrm{V}_{\max } 0.1 \mu \mathrm{g} / \mathrm{min}\right)$. With the highest simulated passive permeability $\left(\mathrm{P}_{\mathrm{app}}=\right.$ $\left.6 \times 10^{-4} \mathrm{~cm} / \mathrm{sec}\right)$, over 5 -fold differences are observed only when the transporter affinity is high $\left(\mathrm{K}_{\mathrm{m}} 0.1 \mu \mathrm{g} / \mathrm{ml}\right.$, corresponding to $0.25 \mu \mathrm{M}$ of a 400 Da compound), and vitreal or systemic drug concentration is low to intermediate $(0.25-2.5 \mu \mathrm{g} / \mathrm{ml}$ and $0.001-10 \mu \mathrm{g} / \mathrm{ml}$, respectively).

Our simulation data clearly shows that efflux proteins on the RPE surface can have a major impact on drug exposure in the RPE by limiting the drug access and/or enhancing the elimination from the RPE compartment. The rate of active transport can define whether the drug reaches its target in the RPE. These findings should be considered carefully in drug discovery: good candidate molecules to treat retinal diseases should not be transported by the efflux proteins, since they can affect the RPE drug exposure in both systemic and intravitreal administration. Our simulations indicate that the impact of active transport on vitreal kinetics is not as dramatic, which was suggested already previously [85-87]. The vitreal drug exposure is affected by several elimination routes, and thus the active transport across the RPE is not a dominating factor. Melanin binding is another important factor defining the drug exposure inside the RPE [88], but the binding was not considered in 
our model. Thus, the active transport might not be the most dominating factor affecting the drug exposure, but our simulations demonstrate that their impact can be significant in certain conditions. Pharmacokinetic impact of melanin binding results from a complex interplay between the membrane permeability and melanin binding kinetics, a situation where active transport may also contribute [88].

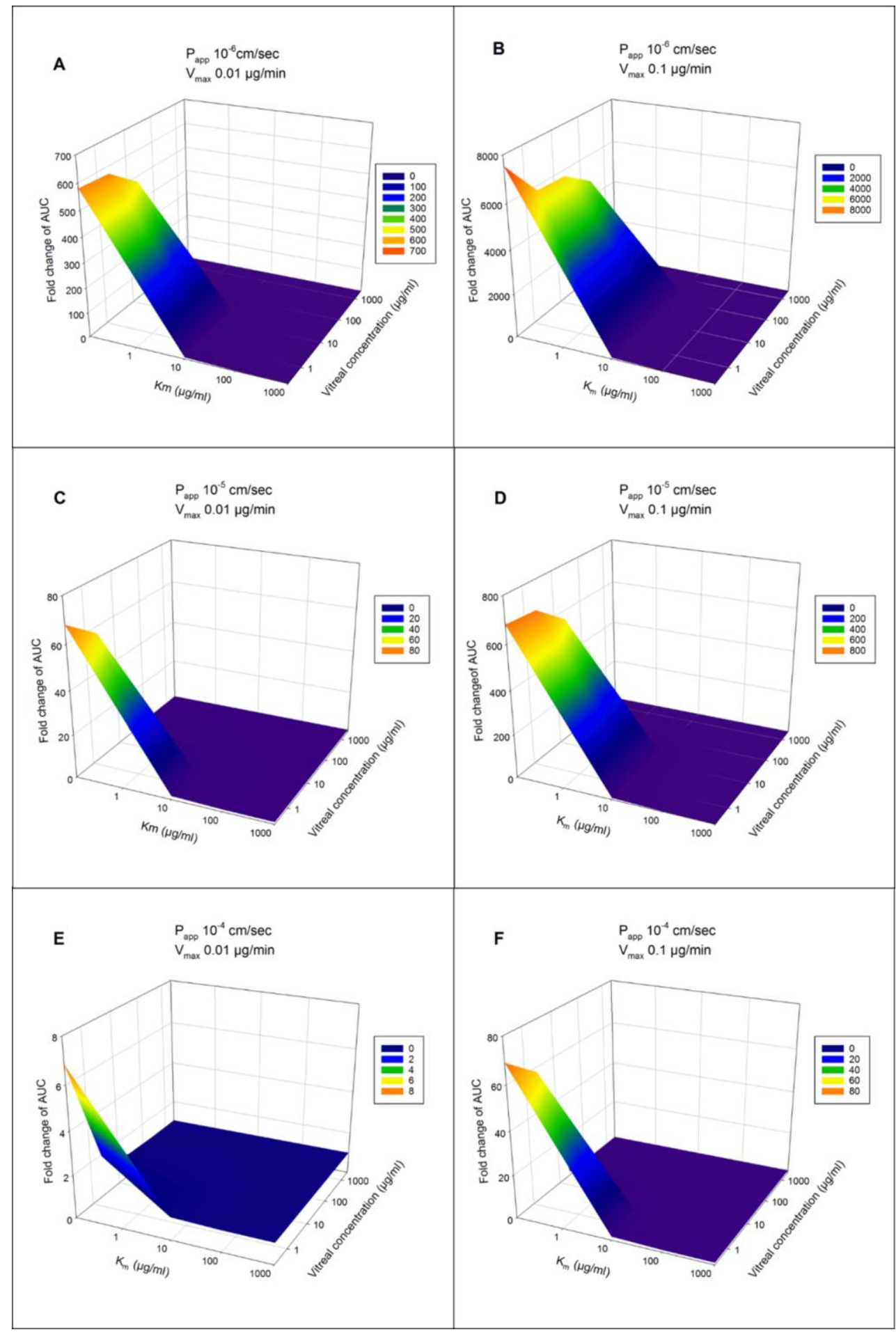


Figure 8. Simulated AUC differences in the RPE compartment with active efflux on the RPE surface compared to only passive diffusion after intravitreal administration. Fold change in the $A \cup C$ ( $A \cup C_{\text {passive }} / A \cup C_{\text {active }}$ ) is shown by the color range. $A$ and $B$ represent the slowest passive permeability $\left(P_{\text {app }} 10^{-6} \mathrm{~cm} / \mathrm{sec}\right), C$ and $D$ intermediate $\left(P_{\text {app }} 10^{-5} \mathrm{~cm} / \mathrm{sec}\right)$ and $E$ and $F$ the fastest passive permeability $\left(P_{\text {app }} 10^{-4} \mathrm{~cm} / \mathrm{sec}\right)$. The left-hand sided column $(A, C, E)$ represents a $V_{\max }$ value of 0.01 $\mu \mathrm{g} / \mathrm{ml}$, and the right-hand sided column (B, D, F) a $V_{\max }$ value of $0.1 \mu \mathrm{g} / \mathrm{ml}$.

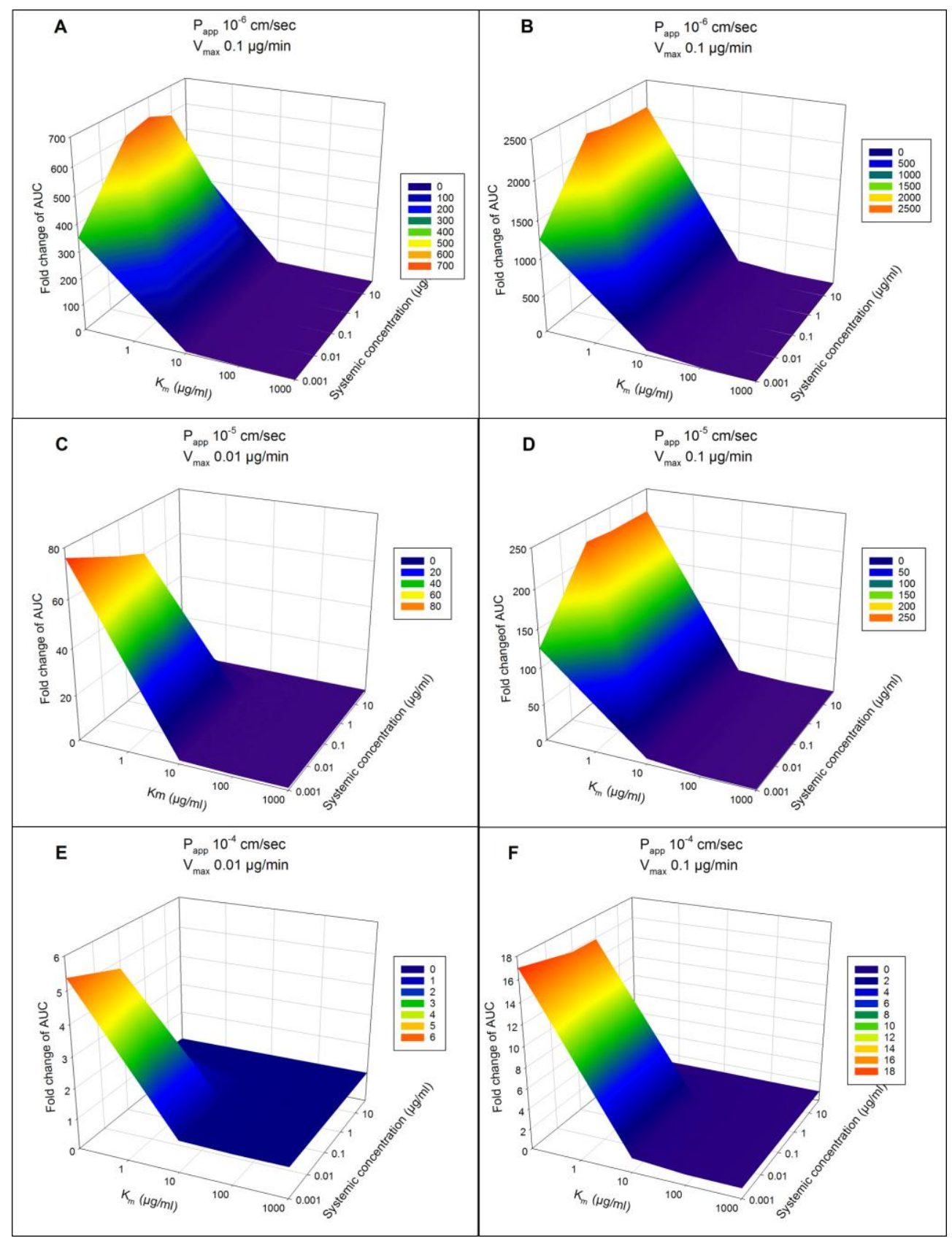

Figure 9. Simulated AUC differences in the RPE compartment with active efflux on the RPE surface compared to only passive diffusion after systemic administration. Fold change in the $A \cup C$ ( $\left.A \cup C_{\text {passive }} / A \cup C_{\text {active }}\right)$ is shown by the color range. $A$ and $B$ represent the slowest passive permeability $\left(P_{\text {app }} 10^{-6} \mathrm{~cm} / \mathrm{sec}\right), C$ and $D$ intermediate $\left(P_{\text {app }} 10^{-5} \mathrm{~cm} / \mathrm{sec}\right)$ and $E$ and $F$ the fastest passive permeability $\left(P_{\text {app }} 10^{-4} \mathrm{~cm} / \mathrm{sec}\right)$. The left-hand sided column $(A, C, E)$ represents a $V_{\max }$ value of 0.01 $\mu \mathrm{g} / \mathrm{ml}$, and right-hand sided column (B, D, F) a $V_{\max }$ value of $0.1 \mu \mathrm{g} / \mathrm{ml}$. 


\section{Pharmacogenetics in ocular transporters}

Many transporter proteins are associated to rare diseases, which are caused by mutations that affect the activity of a transporter. For example, a deletion of three nucleotides in the $A B C C 7$ gene leads to misfolding of the corresponding transporter, and is responsible for $70 \%$ of cystic fibrosis cases. In the eye, mutations in the ABCA4 gene cause the most common form of the Stargardt's disease as well as other blinding diseases affecting the retina [89]. Mutations in MRP6 have been associated with pseudoxanthoma elasticum, a rare hereditary disease resulting in macular degeneration, among other complications [90]. SLC4A11 is a sodium transporter that is involved in sodium-mediated fluid transport in many organs. Mutations in SLC4A11 have been linked to congenital hereditary endothelial dystrophy (CHED), which is a rare disorder of the corneal endothelium, causing corneal oedema and opacification of the cornea [91, 92]. In addition, SLC4A11 has been associated to Fuchs' corneal dystrophy, which is the most common hereditary corneal disease leading to corneal oedema [93].

In addition to disease-causing mutations, the importance of genetic variation in transporters for drug pharmacokinetics and pharmacodynamics is gaining recognition. Numerous transporter polymorphisms are known, but the impact in drug treatment is not yet well characterized for the majority of them. Still, some clinically important variants have been identified, as for instance the OATP1B1 521T<C (SLCO1B1*5) polymorphism that is associated with adverse effects in statin treatment [94]. OATP1B1 is expressed exclusively at the basolateral membrane of hepatocytes, and reduced transport of statin into the hepatocytes cause an increase in plasma levels, which leads to muscle toxicity. In addition to affecting systemic exposure, transporter polymorphisms can affect tissue concentrations. One example is cisplatin-induced nephrotoxicity, which is a common adverse effect in patients receiving cisplatin-containing chemotherapy. Cisplatin is transported into the proximal tubular cells by OCT2 and the OCT2 808G>T polymorphism has been associated with a reduced risk of nephrotoxicity due to lower cellular cisplatin levels [95]. Currently, there are only a few reports on the effects of polymorphisms in transporters on ocular drug pharmacokinetics or pharmacodynamics. The effect of polymorphisms on the response to latanoprost that is used as a treatment for glaucoma has been studied recently. Carriers of a genetic variant of MRP4 ( $r$ 11568658) had significantly lower intraocular pressure after latanoprost treatment, indicating that MRP4 efflux affects the absorption of latanoprost [96]. Similarly, an OATP2A1 genetic variant (rs4241366) was found to have some correlation to the intraocular pressure response after topically applied latanoprost in glaucoma patients [97]. Additionally, a MDR1 variant (3435c>T, rs1045642) was recently associated to the enhanced intraocular pressure response of latanoprost [98]. Notably, several other studied variants of MRP4, MDR1 and OATP2A1 showed no impact on intraocular pressure response after latanoprost or other prostaglandin analog treatment [97, 99]. OATP2A1 and MRP4 are both found at the corneal epithelium (Table 1), but MDR1 has not been detected. The influence of MDR1 polymorphism on topically administered latanoprost might be explained by expression in the conjunctiva or the BAB, but this reasoning does not yet have experimental proof.

Genetic variations in transporters that are expressed at the blood-ocular barriers have been associated with altered drug response for drugs that are also used for ocular diseases. For instance, higher doses of 6mercaptopurine were needed for leukemia patients with homozygous variant allelles of MRP4 [100]. 6mercaptopurine is a metabolite of azathioprine, which is also used as an immunosuppressive agent in noninfectious uveitis and in ocular inflammation, similarly as systemically administered methotrexate. 
Methotrexate can be injected intravitreally to treat B-cell intraocular lymphoma. The clearance of methotrexate was found to increase by an MRP2 polymorphism, causing patients carrying the polymorphism to reach non-toxic levels faster after a high dose of methotrexate [101]. Polymorphisms can also lead to adverse effects, as shown by certain MRP2 polymorphisms that have been associated to methotrexate toxicity [102, 103]. Melphalan can be used to treat pediatric tumor retinoblastoma. A LAT1 polymorphism was found to correlate with gastrointestinal toxicity of melphalan in a recent study [104], while in an earlier study no correlation could be found between LAT1 polymorphisms and melphalan pharmacokinetics or toxicity [105].

\section{Conclusions}

Many ophthalmic drugs are known to interact with drug transporters [106], but whether these interactions have a clinical significance in ocular drug pharmacokinetics and pharmacodynamics, depends on the expression and localization of the interacting transporters in the ocular tissues. The expression of many transporters has been confirmed in the ocular tissues, but their relative or absolute expression levels are mostly not known. This information would be of importance to evaluate the transport rate and subsequently the impact of the active transport, as the permeability of a compound depends on both the active transport and the passive diffusion. Our simulations indicate that active transport may have significant impact on the absorbance of compounds with low passive permeability. Changes in expression levels may occur due to environmental factors, which could affect the pharmacokinetics of drugs. For instance, diseases may affect the expression level of transporters in other tissues and barriers [107], but the effect of diseases on ocular transporter expression levels and impact on drug permeability has not yet been studied.

The corneal epithelium is the most important permeability barrier of a topically administered drug dose. The corneal epithelium expresses several transporters, but based on the available literature and our simulations the clinical significance of active transport on corneal drug permeability in vivo appears to be low. Still, in some cases the active transport might be important. The active transport in the conjunctiva has not been as thoroughly investigated as in the cornea, but directionality of transport has been shown for several substrates. This indicates that active transport might affect drug absorption across the conjunctiva, but there is not yet evidence of significant impact of conjunctival transporters on ocular drug absorption.

Evaluation of the $B A B$ is more difficult, as it consist of several tissues and it can be hard to distinguish the impact of the $B A B$ from the $B R B$ in vivo. Nevertheless, it is clear that the $B A B$ expresses several transporters that can affect drug permeability, but the clinical significance of the active transport is not yet proven.

The neural retina is unlikely to form a barrier for small molecular weight drugs, but as it comprises many cell types that are targeted in ocular diseases, transporters might have a large impact on the drug response. Unfortunately, the presence of transporters in the neuronal retina has been sparsely studied. The influx transporters that have been localized to photoreceptors and neuronal cells could potentially be used for targeting and enhancing uptake of drugs to these cells.

There is evidence for the activity of drug transporters at the BRB, but the clinical significance of drug permeability may vary depending on the route of administration. The active transport is likely to have a higher impact on the total permeability at the low concentrations that are encountered at the BRB after systemic administration, than at the much higher concentrations that are reached after intravitreal administration, 
which are more likely to saturate the transporters in the BRB. In addition, the RPE is by itself an important target tissue and our simulations indicate that efflux transporters can effectively limit drug accumulation in the RPE. Based on the current literature, especially MRP transporters appear to have an important role in RPE permeability.

In some cases the significance of a transporter for the permeability of a drug has been studied in animals where the transporter of interest has been knocked-out. However, this might lead to an increase in the expression levels of other transporters in comparison to the wild-type animal and as there is considerable substrate overlap between many transporters, the higher expression levels of other transporters may obscure the role of the knocked-out protein. Overall, studying the impact of specific transporters in tissues or cells is hampered by the lack of specific substrates and inhibitors. One way to overcome the issue is to study the influence of transporter pharmacogenetics on ocular drug disposition and response. This is a quite unexplored topic, but importantly, in addition to acquiring information on the effect of the variant, these studies present an opportunity to gain insights of the clinical impact of the transporters in vivo in humans. With a few exceptions, the activity of ocular transporters has been studied in vivo only in animals and differences in ocular transporter expression and activity has been shown between species. The species differences in transporter expression need to be considered when interpreting the results from animal studies and extrapolating them to humans.

\section{Acknowledgements}

Eva Ramsay and Eva del Amo are acknowledged for providing Figure 1 and helpful discussions on the anatomy

of the blood-aqueous barrier. This work was supported by the Academy of Finland (grant numbers 257786 and 268868), the Doctoral Programme in Drug Research (University of Eastern Finland), the Finnish Cultural Foundation, and the Sigrid Juselius Foundation. 


\section{Figure captions}

Figure 1. Schematic figure of the anatomy of the eye and the ocular barriers. Bold lines indicate tight barriers, while thin or dashed lines are leakier membranes.

Figure 2. Schematic presentation of corneal and conjunctival transporters for which protein expression and functionality have been reported in tissues or in primary cells. Arrows indicate the direction of transport. For further information, see text, table 1 and table 2.

Figure 3. Schematic presentation of the corneal simulation models. The eye drop is instilled into tear fluid and active transport at the corneal epithelium either increase (influx, model 1) or restrict (efflux, model 2) absorption into the aqueous humor.

Figure 4. Simulations on the effect of corneal influx $(A-C)$ and efflux (D-F) on drug absorption after topical administration of $1 \%$ eye drop. Fold change in the $A \cup C\left(A \cup C_{\text {passive }} / A \cup C_{\text {active }}\right)$ is shown by the color range. The $A \cup C$ in aqueous humour was simulated with $\mathrm{K}_{\mathrm{m}}$ values of $0.1 \mu \mathrm{g} / \mathrm{ml}(\mathrm{A}, \mathrm{D}), 10 \mu \mathrm{g} / \mathrm{ml}(\mathrm{B}, \mathrm{E})$ and $1000 \mu \mathrm{g} / \mathrm{ml}(\mathrm{C}, \mathrm{F})$.

Figure 5. Transporter expression at ocular barriers. A) Expressed transporters and localization of drug transporters at the BRB. ILM, inner limiting membrane; NFL, nerve fiber layer; GCL, ganglion cell layer; IPL, inner plexiform layer; INL, inner nuclear layer; OPL, outer plexiform layer; ONL, outer nuclear layer; OLM, outer limiting membrane; POS, photoreceptors; RPE, retinal pigment epithelium; CHR, choroid. Arrows indicate the direction of transport, and dotted lines indicate that the activity could not be distinguished between inner and outer BRB. Transporters for which the localization to either the apical or basolateral membrane is not determined are placed intracellularly. B) Expressed transporters and localization at the BAB. Transporters for which the localization to either the apical or basolateral membrane is not determined are placed intracellularly. NPE, non-pigmented epithelium and PE, pigmented epithelium.

Figure 6. Quantitative transporter expression in human fetal RPE cells. A) Influx transporters, B) efflux transporters and C) drug transporters whose expression was below the detection limit (data from [69]).

Figure 7. Schematic presentation of RPE simulation models. The drug is delivered to the RPE via intravitreal administration (A) or from the choroidal blood flow by systemic administration (B). Active transport (efflux out from the RPE) is localized either on the apical or basolateral side of the RPE. Both administration routes represent steady state concentrations in the vitreous (A) or in the systemic blood flow (B). Passive diffusion from the systemic blood flow to the RPE was not considered in the intravitreal administration model $(A)$ since the concentration in the systemic circulation is extremely low after intravitreal drug administration.

Figure 8. Simulated AUC differences in the RPE compartment with active efflux on the RPE surface compared to only passive diffusion after intravitreal administration. Fold change in the $A \cup C$ ( $\left.A \cup C_{\text {passive }} / A \cup C_{\text {active }}\right)$ is shown by the color range. $A$ and $B$ represent the slowest passive permeability $\left(P_{\text {app }} 10^{-6} \mathrm{~cm} / \mathrm{sec}\right), C$ and $D$ intermediate $\left(P_{\text {app }} 10^{-5} \mathrm{~cm} / \mathrm{sec}\right)$ and $E$ and $F$ the fastest passive permeability $\left(P_{\text {app }} 10^{-4} \mathrm{~cm} / \mathrm{sec}\right)$. The left-hand sided column $(A, C, E)$ represents a $V_{\text {max }}$ value of 0.01 $\mu \mathrm{g} / \mathrm{ml}$, and the right-hand sided column $(B, D, F)$ a $V_{\max }$ value of $0.1 \mu \mathrm{g} / \mathrm{ml}$.

Figure 9. Simulated AUC differences in the RPE compartment with active efflux on the RPE surface compared to only passive diffusion after systemic administration. Fold change in the $A \cup C\left(A \cup C_{\text {passive }} / A U C_{\text {active }}\right)$ is shown by the color range. $A$ and $B$ represent the slowest passive permeability $\left(P_{\text {app }} 10^{-6} \mathrm{~cm} / \mathrm{sec}\right), C$ and $D$ intermediate $\left(P_{\text {app }} 10^{-5} \mathrm{~cm} / \mathrm{sec}\right)$ and $E$ and $F$ the fastest passive permeability $\left(P_{a p p} 10^{-4} \mathrm{~cm} / \mathrm{sec}\right)$. The left-hand sided column $(A, C, E)$ represents a $V_{\max }$ value of 0.01 $\mu \mathrm{g} / \mathrm{ml}$, and right-hand sided column $(B, D, F)$ a $V_{\max }$ value of $0.1 \mu \mathrm{g} / \mathrm{ml}$. 
Table 1. Efflux protein expression in corneal and conjunctival epithelium

\begin{tabular}{|c|c|c|c|c|c|}
\hline Transporter & Species & Tissue/cells & Detection $^{a}$ & Localization/comments & Ref. \\
\hline \multicolumn{6}{|l|}{ CORNEA } \\
\hline \multirow{5}{*}{$\begin{array}{l}\text { MDR1/P- } \\
\text { glycoprotein }\end{array}$} & Rabbit* & Corneal tissue & $+W B,+I H C$ & Staining in the superficial layer of epithelium & {$[21]$} \\
\hline & & Corneal epithelium & $+W B$ & & [108] \\
\hline & & Primary cells & $+W B$ & & {$[20,108]$} \\
\hline & & $\begin{array}{l}\text { Isolated mitochondria from the } \\
\text { cultured rabbit corneal epithelial cells } \\
\text { (WB) and whole cells (ICC) }\end{array}$ & $+W B,+I C C$ & Staining localized into mitochondria & [109] \\
\hline & Porcine* & Corneal tissue & $-W B,-I H C$ & & {$[21]$} \\
\hline \multirow[t]{4}{*}{ MRP1 } & Human & Corneal epithelium & $+W B,+I H C$ & $\begin{array}{l}\text { Staining predominantly in basal layer, } \\
\text { localized to cell membrane }\end{array}$ & {$[16]$} \\
\hline & & Cultured primary corneal epithelial cells & $+W B$ & & [16] \\
\hline & Rabbit* & Corneal tissue & $+W B,+I H C$ & $\begin{array}{l}\text { Staining predominantly in the superficial } \\
\text { layer of corneal epithelium }\end{array}$ & {$[24]$} \\
\hline & Porcine* & Corneal tissue & $-W B,-I H C$ & & {$[24]$} \\
\hline \multirow[t]{4}{*}{ MRP2 } & Human & Corneal tissue & $+W B$ & & {$[30]$} \\
\hline & Rabbit* & Corneal tissue & $+W B,+I H C$ & Apical localization in corneal epithelium & {$[24]$} \\
\hline & Rabbit & Cultured rabbit corneal epithelial cells & $+W B$ & & [29] \\
\hline & Porcine* & Corneal tissue & $-W B,-I H C$ & & {$[24]$} \\
\hline \multirow[t]{4}{*}{ MRP3 } & Human & Corneal epithelium & $-W B$ & & {$[16]$} \\
\hline & & Cultured primary corneal epithelial cells & $+W B$ & & {$[16]$} \\
\hline & Rabbit & Corneal tissue & $+W B,-I H C$ & & {$[21]$} \\
\hline & Porcine & Corneal tissue & $-W B,+I H C$ & & {$[21]$} \\
\hline \multirow[t]{3}{*}{ MRP4 } & Human & Corneal epithelium & $-W B$ & & {$[16]$} \\
\hline & & Corneal epithelium & $+\mathrm{IHC}$ & & {$[27]$} \\
\hline & & Cultured primary corneal epithelial cells & + WB & & [16] \\
\hline
\end{tabular}




\begin{tabular}{|c|c|c|c|c|c|}
\hline & Rabbit* & Corneal tissue & $-W B,-I H C$ & & {$[24]$} \\
\hline & Porcine* & Corneal tissue & $+W B,+I H C$ & $\begin{array}{l}\text { Predominantly apical staining in the corneal } \\
\text { epithelium }\end{array}$ & {$[24]$} \\
\hline & Rat & Corneal epithelium & $+\mathrm{IHC}$ & $\begin{array}{l}\text { Expression in basal and wing cells of corneal } \\
\text { epithelium }\end{array}$ & [31] \\
\hline \multirow[t]{5}{*}{ MRP5 } & Human & Corneal epithelium & $+W B,+I H C$ & Staining on cell membranes of basal cells & [16] \\
\hline & & Cultured primary corneal epithelial cells & $+W B$ & & {$[16]$} \\
\hline & Rabbit* & Corneal tissue & $+W B,-I H C$ & & {$[24]$} \\
\hline & Porcine* & Corneal tissue & $+W B,+I H C$ & $\begin{array}{l}\text { Positive staining in the corneal epithelium, } \\
\text { predominantly in the apical side }\end{array}$ & {$[24]$} \\
\hline & Rat & Corneal epithelium & $+\mathrm{IHC}$ & Expression in all layers of corneal epithelium & {$[31]$} \\
\hline \multirow[t]{7}{*}{ BCRP } & Human & Corneal epithelium & $+W B$ & & {$[16]$} \\
\hline & & Corneal epithelium & $+\mathrm{IHC}$ & & {$[27]$} \\
\hline & & Cultured primary corneal epithelial cells & $+W B$ & & {$[16]$} \\
\hline & Rabbit* & Corneal tissue & $-W B,-I H C$ & & {$[21]$} \\
\hline & Porcine* & Corneal tissue & $-W B,-I H C$ & & {$[21]$} \\
\hline & Canine & Corneal tissue & $-\mathrm{IHC}$ & $\begin{array}{l}\text { Expression localized in the basal layer of the } \\
\text { limbal epithelium, but not any layers of } \\
\text { central corneal epithelium }\end{array}$ & {$[28]$} \\
\hline & Canine & Cultured primary corneal epithelial cells & $-I C C$ & $\begin{array}{l}\text { Not detected in the corneal or limbal } \\
\text { epithelial cells after subculture }\end{array}$ & {$[28]$} \\
\hline \multicolumn{6}{|c|}{ CONJUNCTIVA } \\
\hline $\begin{array}{l}\text { MDR1/P- } \\
\text { glycoprotein }\end{array}$ & Rabbit & $\begin{array}{l}\text { Conjunctival tissue and primary cells } \\
\text { grown on membrane }\end{array}$ & $+W B,+I H C$ & Localization on apical site & {$[42,43]$} \\
\hline MRP1 & Rabbit & $\begin{array}{l}\text { Conjunctival tissue and primary cells } \\
\text { grown on membrane }\end{array}$ & $+W B,+I H C$ & Localization on basolateral site & [44] \\
\hline
\end{tabular}

${ }^{a}$ WB, western blot; IHC, immunohistochemistry *Antibody used was not specific for rabbit/porcine antigen 
Table 2. Influx protein expression in corneal and conjunctival epithelium

\begin{tabular}{|c|c|c|c|c|c|}
\hline Transporter & Species & Tissue/cells & Detection & Localization/comments & References \\
\hline \multicolumn{6}{|l|}{ CORNEA } \\
\hline \multirow[t]{4}{*}{ MCT1 } & Human & Corneal epithelium & $+W B$ & & {$[34]$} \\
\hline & & Cultured primary corneal epithelial cells & $+W B$ & & [34] \\
\hline & Rabbit & $\begin{array}{l}\text { Primary corneal epithelial cells grown } \\
\text { on support membrane }\end{array}$ & $+I C C$ & $\begin{array}{l}\text { Staining especially on superficial cells, some } \\
\text { also on intermedialte layers }\end{array}$ & [110] \\
\hline & Rat & Corneal epithelium & $+\mathrm{IHC}$ & $\begin{array}{l}\text { Labeling in the epithelium, concentrated } \\
\text { toward stroma }\end{array}$ & [111] \\
\hline \multirow[t]{2}{*}{ MCT2 } & Rabbit & $\begin{array}{l}\text { Primary corneal epithelial cells grown } \\
\text { on support membrane }\end{array}$ & $+\mathrm{ICC}$ & Staining in all cell layers & [110] \\
\hline & Rat & Corneal epithelium & $+\mathrm{IHC}$ & & [111] \\
\hline МСТ3 & Rat & Corneal epithelium & $+/-\mathrm{IHC}$ & Antibody-dependent staining & [111] \\
\hline \multirow[t]{3}{*}{ MCT4 } & Human & Corneal epithelium & $+W B$ & & [34] \\
\hline & & Cultured primary corneal epithelial cells & $+W B$ & & {$[34]$} \\
\hline & Rabbit & $\begin{array}{l}\text { Primary corneal epithelial cells grown } \\
\text { on support membrane }\end{array}$ & $+I C C$ & Staining especially on superficial cells & [110] \\
\hline MCT5 & Rabbit & $\begin{array}{l}\text { Primary corneal epithelial cells grown } \\
\text { on support membrane }\end{array}$ & $+\mathrm{ICC}$ & Staining especially on superficial cells & [110] \\
\hline OAT2 & Human & Corneal epithelium & $+\mathrm{IHC}$ & & [27] \\
\hline OAT3 & Rat & Corneal tissue & $-\mathrm{IHC}$ & & [31] \\
\hline OATP2A1 & Human & Corneal epithelium & $+\mathrm{IHC}$ & $\begin{array}{l}\text { Immunoreactivity particularly in superficial } \\
\text { layers, but also basal cells, of corneal } \\
\text { epithelium }\end{array}$ & [112] \\
\hline OATP2B1 & Human & Corneal epithelium & $+\mathrm{IHC}$ & $\begin{array}{l}\text { Immunoreactivity in basal and superficial } \\
\text { layers of corneal epithelium }\end{array}$ & [112] \\
\hline
\end{tabular}




\begin{tabular}{|c|c|c|c|c|c|}
\hline OATP4A1 & Rat & Corneal tissue & $+W B,+I H C$ & $\begin{array}{l}\text { Immunostaining in all layers of corneal } \\
\text { epithelium, but especially in the stroma of } \\
\text { basal cells and wing cells }\end{array}$ & [113] \\
\hline ОСТ3 & Human & Corneal epithelium & $+\mathrm{IHC}$ & & {$[27]$} \\
\hline OCTN1 & Rabbit & Corneal epithelium & $+\mathrm{IHC}$ & $\begin{array}{l}\text { Expression predominantly on the apical } \\
\text { surface of the epithelium }\end{array}$ & [114] \\
\hline OCTN2 & Rabbit & Corneal epithelium & $+\mathrm{IHC}$ & $\begin{array}{l}\text { Expression predominantly on the apical } \\
\text { surface of the epithelium }\end{array}$ & [114] \\
\hline PEPT1 & Rabbit & $\begin{array}{l}\text { Isolated mitochondria from the } \\
\text { cultured primary rabbit corneal } \\
\text { epithelial cells (WB) and whole cells } \\
\text { (ICC) }\end{array}$ & $+W B,+I C C$ & PEPT1 staining localized into mitochondria & [109] \\
\hline 4F2hc heavy chain & Human & Corneal epithelium & $+\mathrm{IHC}$ & Detected in all corneal epithelial layers & [115] \\
\hline \multicolumn{6}{|l|}{ CONJUNCTIVA } \\
\hline OCTN1 & Rabbit & Conjunctival tissue & $+\mathrm{HHC}$ & Localization on apical site & [114] \\
\hline OCTN2 & Rabbit & Conjunctival tissue & $+\mathrm{IHC}$ & Localization on apical site & [114] \\
\hline OATP2A1 & Human & Conjunctival tissue & $+\mathrm{HHC}$ & $\begin{array}{l}\text { Suprabasal epithelial cell of bulbar } \\
\text { conjunctiva }\end{array}$ & [112] \\
\hline OATP2B1 & Human & Conjunctival tissue & $+\mathrm{HHC}$ & Basal and superficial cells of conjunctiva & [112] \\
\hline
\end{tabular}

${ }^{\mathrm{a}}$ WB, western blot; IHC, immunohistochemistry 
Table 3. Transporter protein expression in BAB

\begin{tabular}{|c|c|c|c|c|c|}
\hline Transporter & Species & Tissue/cells & $\begin{array}{l}\text { Detection } \\
\text { method }^{\mathrm{a}}\end{array}$ & Localization /comments $^{\mathrm{b}}$ & Ref. \\
\hline \multicolumn{6}{|l|}{$\begin{array}{l}\text { EFFLUX } \\
\text { TRANSPORTERS }\end{array}$} \\
\hline \multirow[t]{5}{*}{ P-glycoprotein } & Bovine & Primary fresh NPE cells & $+\mathrm{IHC}$ & & [116] \\
\hline & Human & Ciliary body & $+W B$ & & [30] \\
\hline & Rat & Iris & $+\mathrm{IHC}$ & Capillaries & [117] \\
\hline & $\begin{array}{l}\text { Human } \\
\text { Rabbit } \\
\text { Monkey } \\
\text { Calf } \\
\text { Sheep }\end{array}$ & $\begin{array}{l}\text { Iris } \\
\text { Ciliary muscle }\end{array}$ & $+\mathrm{HHC}$ & Capillaries & [118] \\
\hline & Human & Iris & $-W B$ & & {$[30]$} \\
\hline \multirow[t]{2}{*}{ MRP1 } & Human & Ciliary body & $+W B$ & & [30] \\
\hline & Human & Iris & $+W B$ & & {$[30]$} \\
\hline \multirow[t]{3}{*}{ MRP2 } & Human & Ciliary body & $\begin{array}{l}+W B \\
+ \text { IHC }\end{array}$ & $\begin{array}{l}\text { Apical membrane of NPE, both pars } \\
\text { plana and pars plicata* }\end{array}$ & [30] \\
\hline & Porcine & $\begin{array}{l}\text { freshly dissected and } \\
\text { cultured NPE }\end{array}$ & $\begin{array}{l}+\mathrm{IHC} \\
+\mathrm{WB}\end{array}$ & Apical membrane of NPE* & {$[30]$} \\
\hline & Human & Iris & $+W B$ & & [30] \\
\hline \multirow[t]{3}{*}{ MRP4 } & Human & Ciliary body & $+W B$ & & {$[30]$} \\
\hline & Human & Ciliary body & $\begin{array}{l}+\mathrm{WB} \\
+\mathrm{IHC}\end{array}$ & Basolateral membrane of PE cells & {$[61]$} \\
\hline & Human & Iris & $+W B$ & & {$[30]$} \\
\hline \multirow[t]{2}{*}{ BCRP } & Human & Ciliary body & $+W B$ & & [30] \\
\hline & Human & Iris & $+W B$ & & {$[30]$} \\
\hline \multicolumn{6}{|l|}{$\begin{array}{l}\text { INFLUX } \\
\text { TRANSPORTERS }\end{array}$} \\
\hline МCT1 & & Ciliary body & $+\mathrm{HHC}$ & NPE & [111] \\
\hline MCT2 & & Ciliary body & $+\mathrm{IHC}$ & NPE & [111] \\
\hline Oatp1a4 & Rat & Ciliary body & $\begin{array}{l}+\mathrm{WB} \\
+\mathrm{IHC}\end{array}$ & $\begin{array}{l}\text { Basolateral membrane of NPE (pars } \\
\text { plicata and plana) }\end{array}$ & [59] \\
\hline Oatp1a5 & Rat & Ciliary body & $\begin{array}{l}+W B \\
-I H C\end{array}$ & $\begin{array}{l}\text { Not detected in ciliary body epithelium } \\
\text { by IHC }\end{array}$ & {$[57]$} \\
\hline Oatp1b2 & Rat & Ciliary body & $+W B$ & Basolateral membrane of NPE (pars & [57] \\
\hline
\end{tabular}




\begin{tabular}{|c|c|c|c|c|c|}
\hline & & & $+\mathrm{IHC}$ & plicata and plana) & \\
\hline OATP1A2 & Human & Ciliary body & $\begin{array}{l}+\mathrm{WB} \\
+\mathrm{IHC}\end{array}$ & $\begin{array}{l}\text { Basolateral membrane of NPE (only pars } \\
\text { plana) }\end{array}$ & {$[57]$} \\
\hline OATP1C1 & Human & Ciliary body & $\begin{array}{l}+\mathrm{WB} \\
+\mathrm{IHC}\end{array}$ & $\begin{array}{l}\text { Basolateral membrane of NPE and PE } \\
\text { (only pars plana) }\end{array}$ & {$[57]$} \\
\hline OATP2A1 & Human & Ciliary body & $+\mathrm{IHC}$ & $\begin{array}{l}\text { Basalateral membrane of NPE and PE } \\
\text { pars plicata }\end{array}$ & {$[57]$} \\
\hline OATP2A1 & Human & Iris & $+\mathrm{IHC}$ & Capillaries & {$[112]$} \\
\hline OATP2B1 & Human & Ciliary body & $\begin{array}{l}+ \text { WB } \\
+\mathrm{IHC}\end{array}$ & $\begin{array}{l}\text { Basolateral membrane of NPE (pars } \\
\text { plicata and plana) }\end{array}$ & {$[57]$} \\
\hline OATP2B1 & Human & Ciliary body & $+\mathrm{IHC}$ & Basal membranes of NPE and PE & {$[112]$} \\
\hline OATP2B1 & Human & Iris & $+\mathrm{IHC}$ & Capillaries & [112] \\
\hline OATP3A1 & Human & Ciliary body & $\begin{array}{l}+ \text { WB } \\
+\mathrm{IHC}\end{array}$ & $\begin{array}{l}\text { Basolateral membrane of NPE (pars } \\
\text { plicata and plana) and PE pars plana }\end{array}$ & {$[57]$} \\
\hline OATP4A1 & Human & Ciliary body & $\begin{array}{l}+\mathrm{WB} \\
+\mathrm{IHC}\end{array}$ & $\begin{array}{l}\text { Basolateral membrane of NPE (pars } \\
\text { plicata and plana) and PE pars plana }\end{array}$ & {$[57]$} \\
\hline Oatp4a1 (Oatp-E) & Rat & Ciliary body & $+\mathrm{IHC}$ & NPE and PE & [113] \\
\hline OAT1 & Human & Ciliary body & $\begin{array}{l}+ \text { WB } \\
+\mathrm{IHC}\end{array}$ & Basolateral membranes of NPE & {$[61]$} \\
\hline OAT3 & Human & Ciliary body & $\begin{array}{l}+\mathrm{WB} \\
+\mathrm{IHC}\end{array}$ & Basolateral membranes of NPE & {$[61]$} \\
\hline
\end{tabular}

${ }^{a}$ WB, western blot; IHC, immunohistochemistry ${ }^{b}$ NPE, Non-pigmented epithelial cells of ciliary body; PE, Pigmented epithelial cells of ciliary body

* localization also on apical membrane of PE cannot be excluded 
Table 4. Transporter protein expression in blood-retinal barrier.

\begin{tabular}{|c|c|c|c|c|c|}
\hline Transporter & Species & Tissue/cells & Detection $^{\mathrm{a}}$ & Localization/comments & Ref. \\
\hline \multicolumn{6}{|l|}{$\begin{array}{l}\text { EFFLUX } \\
\text { PROTEINS }\end{array}$} \\
\hline \multicolumn{6}{|l|}{$\begin{array}{l}\text { P- } \\
\text { glycoprotein }\end{array}$} \\
\hline \multicolumn{6}{|l|}{ OBRB } \\
\hline & Human & RPE tissue & $+\mathrm{IHC}$ & apical and basolateral membranes of the RPE & [119] \\
\hline & Human & $\begin{array}{l}\text { hfRPE cells, plasma membrane } \\
\text { fraction }\end{array}$ & $\begin{array}{l}-\mathrm{LC}- \\
\mathrm{MS} / \mathrm{MS}\end{array}$ & & {$[69,82]$} \\
\hline & Porcine & RPE-choroid tissue sheets & $+\mathrm{IHC}$ & & [74] \\
\hline \multicolumn{6}{|l|}{ iBRB } \\
\hline & Mouse & retina ( $\mathrm{RPE}$ removed) & $+\mathrm{IHC}$ & retinal endothelium & {$[120]$} \\
\hline & Mouse & retina & $+\mathrm{IHC}$ & detected in inner BRB, not in the RPE & [70] \\
\hline & Rat & retina & $+\mathrm{IHC}$ & luminal side in the iBRB & {$[121]$} \\
\hline & Bovine & cultured retinal endothelial cells & $+W B$ & & [122] \\
\hline \multicolumn{6}{|c|}{ - } \\
\hline \multicolumn{6}{|l|}{ OBRB } \\
\hline & Human & $\begin{array}{l}\text { hfRPE cells, plasma membrane } \\
\text { fraction }\end{array}$ & $\begin{array}{l}- \text { LC- } \\
\text { MS/MS }\end{array}$ & & {$[69,82]$} \\
\hline & Human & hfRPE cells & $-W B$ & & [123] \\
\hline & Bovine & RPE tissue & $-W B$ & human ab used & [123] \\
\hline & Mouse & RPE & $+\mathrm{IHC}$ & $\begin{array}{l}\text { expression in the RPE mainly on the } \\
\text { basolateral membrane }\end{array}$ & [124] \\
\hline \multicolumn{6}{|c|}{ (1) } \\
\hline & Mouse & retina (RPE removed) & $+\mathrm{IHC}$ & retinal endothelium & [120] \\
\hline & Mouse & retina & $\begin{array}{l}+\mathrm{IHC} \\
+\mathrm{WB}\end{array}$ & $\begin{array}{l}\text { luminal membrane of retinal capillary } \\
\text { endothelial cells }\end{array}$ & [125] \\
\hline & Mouse & retina & $+\mathrm{IHC}$ & detected in inner BRB, not RPE & [70] \\
\hline \multicolumn{6}{|l|}{ MRP's } \\
\hline \multicolumn{6}{|l|}{ MRP1 } \\
\hline \multicolumn{6}{|l|}{ OBRB } \\
\hline & Porcine & RPE-choroid tissue & $+\mathrm{IHC}$ & MRP protein not specified with number & [74] \\
\hline & Human & $\begin{array}{l}\text { hfRPE cells, plasma membrane } \\
\text { fraction }\end{array}$ & $\begin{array}{l}+\mathrm{LC}- \\
\mathrm{MS} / \mathrm{MS}\end{array}$ & & {$[69,82]$} \\
\hline
\end{tabular}




\begin{tabular}{|c|c|c|c|c|c|}
\hline & & & $+I H C$ & & \\
\hline & Human & hESC-RPE & $+W B$ & apical plasma membrane & [126] \\
\hline & & & $+\mathrm{IHC}$ & & \\
\hline & Human & cultured RPE cells & $+W B$ & & {$[127]$} \\
\hline & Horse & RPE tissue, membrane fraction & $\begin{array}{l}+\mathrm{LC}- \\
\mathrm{MS} / \mathrm{MS}\end{array}$ & & [128] \\
\hline \multicolumn{6}{|l|}{ iBRB } \\
\hline & Mouse & retina ( $\mathrm{RPE}$ removed) & $-\mathrm{IHC}$ & not detected in retinal endothelium & [120] \\
\hline & Human & retina & $-\mathrm{IHC}$ & not detected in any regions of the retina & [27] \\
\hline \multicolumn{6}{|c|}{, } \\
\hline \multicolumn{6}{|l|}{ OBRB } \\
\hline & Human & $\begin{array}{l}\text { hfRPE cells, plasma membrane } \\
\text { fraction }\end{array}$ & $\begin{array}{l}- \text { LC- } \\
\text { MS/MS }\end{array}$ & & {$[69,82]$} \\
\hline \multicolumn{6}{|l|}{ iBRB } \\
\hline & Mouse & retina (RPE removed) & $-\mathrm{IHC}$ & not detected in retinal endothelium & [120] \\
\hline \multicolumn{6}{|c|}{ 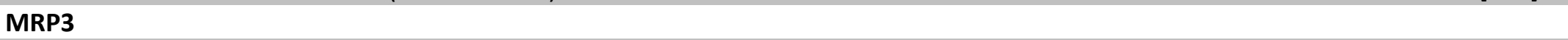 } \\
\hline \multicolumn{6}{|l|}{ OBRB } \\
\hline & Human & $\begin{array}{l}\text { hfRPE cells, plasma membrane } \\
\text { fraction }\end{array}$ & $\begin{array}{l}- \text { LC- } \\
M S / M S\end{array}$ & & {$[69,82]$} \\
\hline \multicolumn{6}{|l|}{ iBRB } \\
\hline & Mouse & retina (RPE removed) & $-\mathrm{IHC}$ & not detected in retinal endothelium & {$[120]$} \\
\hline \multicolumn{6}{|c|}{ 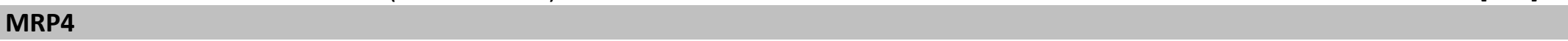 } \\
\hline \multicolumn{6}{|l|}{ OBRB } \\
\hline & Human & $\begin{array}{l}\text { hfRPE cells, plasma membrane } \\
\text { fraction }\end{array}$ & $\begin{array}{l}+\mathrm{LC}- \\
\mathrm{MS} / \mathrm{MS}\end{array}$ & & {$[69,82]$} \\
\hline & & hESC-RPE & $+W B$ & apical plasma membrane & {$[126]$} \\
\hline & & & $+\mathrm{IHC}$ & & \\
\hline & Mouse & RPE & $+\mathrm{IHC}$ & $\begin{array}{l}\text { experessed in the basolateral membrane } \\
\text { of the RPE but not in the inner BRB }\end{array}$ & [70] \\
\hline \multicolumn{6}{|l|}{ iBRB } \\
\hline & Mouse & retina (RPE removed) & $+\mathrm{IHC}$ & retinal endothelium & [120] \\
\hline
\end{tabular}




\begin{tabular}{|c|c|c|c|c|c|}
\hline \multicolumn{6}{|l|}{ MRP5 } \\
\hline \multicolumn{6}{|l|}{ OBRB } \\
\hline & Human & $\begin{array}{l}\text { hfRPE cells, plasma membrane } \\
\text { fraction }\end{array}$ & $\begin{array}{l}+ \text { LC- } \\
\text { MS/MS }\end{array}$ & & {$[69,82]$} \\
\hline & Human & hESC-RPE & $\begin{array}{l}+W B \\
+I H C\end{array}$ & apical plasma membrane & [126] \\
\hline \multicolumn{6}{|l|}{ iBRB } \\
\hline & Human & retina & $-\mathrm{IHC}$ & Undetectable in all regions of the retina & [27] \\
\hline \multicolumn{6}{|l|}{ MRP6 } \\
\hline \multicolumn{6}{|l|}{ OBRB } \\
\hline & Human & $\begin{array}{l}\text { hfRPE cells, plasma membrane } \\
\text { fraction }\end{array}$ & $\begin{array}{l}\text { - LC- } \\
\text { MS/MS }\end{array}$ & & {$[69,82]$} \\
\hline \multicolumn{6}{|l|}{ MRP7 } \\
\hline \multicolumn{6}{|l|}{ OBRB } \\
\hline & Human & cultured hfRPE cells & $\begin{array}{l}+ \text { LC- } \\
\text { MS/MS }\end{array}$ & & {$[69,82]$} \\
\hline \multicolumn{6}{|c|}{$\begin{array}{l}\text { INFLUX } \\
\text { PROTEINS }\end{array}$} \\
\hline \multicolumn{6}{|l|}{ МСТ1 } \\
\hline \multicolumn{6}{|l|}{ OBRB } \\
\hline & Human & RPE tissue & $+\mathrm{IHC}$ & apical membrane of the RPE & [129] \\
\hline & & $\begin{array}{l}\text { hfRPE cells, plasma membrane } \\
\text { fraction }\end{array}$ & $\begin{array}{l}+\mathrm{LC}- \\
\mathrm{MS} / \mathrm{MS} \\
+\mathrm{IHC}\end{array}$ & apical membrane of hfRPE cells & {$[69,82]$} \\
\hline & Mouse & RPE & $+\mathrm{IHC}$ & apical membrane of the RPE & [124] \\
\hline & Mouse & RPE apical microvilli & $\begin{array}{l}+\mathrm{LC}- \\
\mathrm{MS} / \mathrm{MS}\end{array}$ & & [130] \\
\hline & Mouse & RPE apical microvilli and cell bodies & $\begin{array}{l}+ \text { LC- } \\
\text { MS/MS }\end{array}$ & $\begin{array}{l}\text { Detected in both fractions and in young and } \\
\text { old mice }\end{array}$ & [131] \\
\hline & Rat & retina & $+W B$ & apical membrane of the RPE & [132] \\
\hline
\end{tabular}




\begin{tabular}{|c|c|c|c|c|c|}
\hline & & & $\begin{array}{l}\text { (RPE and } \\
\text { NR) } \\
+\mathrm{IHC}\end{array}$ & & \\
\hline & Rat & RPE & $+W B$ & & [133] \\
\hline & Horse & RPE tissue, membrane fraction & $\begin{array}{l}+\mathrm{LC}- \\
\mathrm{MS} / \mathrm{MS}\end{array}$ & & {$[128]$} \\
\hline \multicolumn{6}{|l|}{$\begin{array}{l}\text { iBRB and } \\
\text { oBRB }\end{array}$} \\
\hline & Rat & retina and choroid & $+\mathrm{IHC}$ & $\begin{array}{l}\text { IEM: apical membrane of the RPE, non- } \\
\text { endothelial choroidal elements, retinal } \\
\text { capillaries of the nuclear and plexiform } \\
\text { layers (luminal and abluminal membranes) }\end{array}$ & {$[134]$} \\
\hline & Rat & retina & + WB & & [133] \\
\hline \multicolumn{6}{|l|}{ MCT2 } \\
\hline \multicolumn{6}{|l|}{$\begin{array}{l}\text { iBRB and } \\
\text { oBRB }\end{array}$} \\
\hline & Rat & retina and choroid & $\begin{array}{l}+\mathrm{IHC} \\
\text { (retina) } \\
-\mathrm{IHC} \\
\text { (choroid) }\end{array}$ & $\begin{array}{l}\text { IEM: MCT2 reactivity } \\
\text { was not detected in the choroid, the RPE } \\
\text { cells, or retinal endothelial } \\
\text { cells }\end{array}$ & {$[134]$} \\
\hline & Rat & RPE & $\begin{array}{l}+W B \\
+\mathrm{IHC}\end{array}$ & faint expression throughout the RPE & {$[133]$} \\
\hline & Rat & retina & $\begin{array}{l}+\mathrm{WB} \\
+\mathrm{IHC}\end{array}$ & $\begin{array}{l}\text { faint expression throughout } \\
\text { the inner retina }\end{array}$ & {$[133]$} \\
\hline \multicolumn{6}{|l|}{ MCT3 } \\
\hline \multicolumn{6}{|l|}{ OBRB } \\
\hline & Human & RPE tissue & $+\mathrm{IHC}$ & basolateral membrane & [129] \\
\hline & Human & $\begin{array}{l}\text { hfRPE cells, plasma membrane } \\
\text { fraction }\end{array}$ & $\begin{array}{l}- \text { LC- } \\
\text { MS/MS }\end{array}$ & & {$[69,82]$} \\
\hline & Mouse & RPE apical microvilli and cell bodies & $\begin{array}{l}+\mathrm{LC}- \\
\mathrm{MS} / \mathrm{MS}\end{array}$ & $\begin{array}{l}\text { Detected in both fractions in young mice, } \\
\text { only in cell bodies in old mice }\end{array}$ & {$[131]$} \\
\hline & Rat & retina & $+\mathrm{WB}$ & basolateral membrane of the RPE & [132] \\
\hline
\end{tabular}




\begin{tabular}{|c|c|c|c|c|c|}
\hline & & & $+\mathrm{IHC}$ & & \\
\hline & \multirow[t]{2}{*}{ Rat } & \multirow[t]{2}{*}{ retina } & $-W B$ & only in the RPE & \multirow[t]{2}{*}{ [133] } \\
\hline & & & $-\mathrm{IHC}$ & & \\
\hline & \multirow[t]{2}{*}{ Rat } & \multirow[t]{2}{*}{ RPE } & $+W B$ & basolateral membrane & \multirow[t]{2}{*}{ [133] } \\
\hline & & & $+\mathrm{IHC}$ & & \\
\hline \multicolumn{6}{|l|}{ MCT4 } \\
\hline \multicolumn{6}{|l|}{ OBRB } \\
\hline & Human & $\begin{array}{l}\text { hfRPE cells, plasma membrane } \\
\text { fraction }\end{array}$ & $\begin{array}{l}+ \text { LC- } \\
\text { MS/MS }\end{array}$ & & {$[69,82]$} \\
\hline & \multirow[t]{2}{*}{ Rat } & \multirow[t]{2}{*}{ RPE } & $-W B$ & & \multirow[t]{2}{*}{ [133] } \\
\hline & & & $-\mathrm{IHC}$ & & \\
\hline \multicolumn{6}{|l|}{ iBRB } \\
\hline & \multirow[t]{2}{*}{ Rat } & \multirow[t]{2}{*}{ retina } & $+W B$ & faint expression in iBRB (IHC) & \multirow[t]{2}{*}{ [133] } \\
\hline & & & $+\mathrm{IHC}$ & & \\
\hline \multicolumn{6}{|l|}{ OCT1 } \\
\hline \multicolumn{6}{|l|}{ OBRB } \\
\hline & \multirow[t]{2}{*}{ Human } & \multirow[t]{2}{*}{ hfRPE cells } & - LC- & & \multirow[t]{2}{*}[69,82]{} \\
\hline & & & MS/MS & & \\
\hline \multicolumn{6}{|l|}{ OCT2 } \\
\hline \multicolumn{6}{|l|}{ OBRB } \\
\hline & \multirow[t]{2}{*}{ Human } & \multirow[t]{2}{*}{ hfRPE cells } & - LC- & & \multirow[t]{2}{*}[69,82]{} \\
\hline & & & MS/MS & & \\
\hline \multicolumn{6}{|l|}{ ОСТ3 } \\
\hline \multicolumn{6}{|l|}{ OBRB } \\
\hline & Human & retina & $+\mathrm{IHC}$ & RPE & [27] \\
\hline & Human & hfRPE cells, plasma membrane & - LC- & & {$[69,82]$} \\
\hline & & fraction & $\mathrm{MS} / \mathrm{MS}$ & & \\
\hline OAT1 & & & & & \\
\hline OBRB & & & & & \\
\hline & Human & $\begin{array}{l}\text { hfRPE cells, plasma membrane } \\
\text { fraction }\end{array}$ & $\begin{array}{l}- \text { LC- } \\
\text { MS/MS }\end{array}$ & & {$[69,82]$} \\
\hline OAT2 & & & & & \\
\hline OBRB & & & & & \\
\hline & Human & $\begin{array}{l}\text { hfRPE cells, plasma membrane } \\
\text { fraction }\end{array}$ & $\begin{array}{l}+\mathrm{LC}- \\
\mathrm{MS} / \mathrm{MS}\end{array}$ & & {$[69,82]$} \\
\hline
\end{tabular}




\begin{tabular}{|c|c|c|c|c|c|}
\hline \multicolumn{6}{|l|}{ OAT3 } \\
\hline \multicolumn{6}{|l|}{ OBRB } \\
\hline & Human & $\begin{array}{l}\text { hfRPE cells, plasma membrane } \\
\text { fraction }\end{array}$ & $\begin{array}{l}- \text { LC- } \\
\text { MS/MS }\end{array}$ & & {$[69,82]$} \\
\hline \multicolumn{6}{|c|}{ (1) } \\
\hline & Human & Cultured retinal endothelial cells & $+W B$ & & [121] \\
\hline & Rat & Retina & $+W B$ & $\begin{array}{l}\text { abluminal membrane of retinal endothelial } \\
\text { cells }\end{array}$ & [121] \\
\hline \multicolumn{6}{|c|}{ OATP1A2 } \\
\hline \multicolumn{6}{|c|}{ OBRB } \\
\hline & Human & RPE tissue & $+\mathrm{IHC}$ & mainly on the apical membrane & [135] \\
\hline & Human & cultured adult RPE cells & $+W B$ & & [135] \\
\hline & Horse & RPE tissue, membrane fraction & $\begin{array}{l}+\mathrm{LC}- \\
\mathrm{MS} / \mathrm{MS}\end{array}$ & & [128] \\
\hline \multicolumn{6}{|c|}{ OATP1A4 } \\
\hline \multicolumn{6}{|c|}{$\begin{array}{l}\text { iBRB and } \\
\text { OBRB }\end{array}$} \\
\hline & Rat & Retina & $\begin{array}{l}+W B \\
+I H C\end{array}$ & $\begin{array}{l}\text { expression inner BRB (luminal and abluminal) } \\
\text { and in the apical membrane of the RPE }\end{array}$ & [136] \\
\hline \multicolumn{6}{|c|}{ OATP1C1 } \\
\hline \multicolumn{6}{|c|}{$\begin{array}{l}\text { iBRB and } \\
\text { OBRB }\end{array}$} \\
\hline & Rat & Retina & $\begin{array}{l}+W B \\
+I H C\end{array}$ & $\begin{array}{l}\text { expression inner BRB (luminal and abluminal) } \\
\text { and in the apical and basolateral membranes } \\
\text { of the RPE }\end{array}$ & {$[136]$} \\
\hline \multicolumn{6}{|c|}{ OATP2A1 } \\
\hline \multicolumn{6}{|l|}{ OBRB } \\
\hline & Human & RPE tissue & $+\mathrm{IHC}$ & & [137] \\
\hline \multicolumn{6}{|c|}{ OATP1B3 } \\
\hline \multicolumn{6}{|c|}{$\begin{array}{l}\text { iBRB and } \\
\text { oBRB }\end{array}$} \\
\hline & Human & retina & $-\mathrm{IHC}$ & Undetectable in all regions of the retina & {$[27]$} \\
\hline \multicolumn{6}{|c|}{ OATP2B1 } \\
\hline OBRB & & & & & \\
\hline
\end{tabular}




\begin{tabular}{|c|c|c|c|c|}
\hline & Human & RPE tissue & $+\mathrm{IHC}$ & [137] \\
\hline \multicolumn{5}{|l|}{ LAT1 } \\
\hline \multicolumn{5}{|l|}{ OBRB } \\
\hline & Human & $\begin{array}{l}\text { hfRPE cells, plasma membrane } \\
\text { fraction }\end{array}$ & $\begin{array}{l}+\mathrm{LC}- \\
\mathrm{MS} / \mathrm{MS}\end{array}$ & {$[69,82]$} \\
\hline \multicolumn{5}{|l|}{ iBRB } \\
\hline & Human & $\begin{array}{l}\text { primary cultured retinal endothelial } \\
\text { cells }\end{array}$ & $+W B$ & [64] \\
\hline & Rat & retina & $\begin{array}{l}+ \text { WB } \quad \text { Expressed in the inner BRB } \\
+\mathrm{IHC}\end{array}$ & [64] \\
\hline
\end{tabular}




\section{References}

[1] D.M. Maurice, S. Mishima, Ocular pharmacokinetics, in: M.L. Sears (Ed.), Handbook of experimental pharmacology. Springer Verlag, Berlin-Heidelberg, 1984, pp. 16-119.

[2] V.H. Lee, J.R. Robinson, Mechanistic and quantitative evaluation of precorneal pilocarpine disposition in albino rabbits, J. Pharm. Sci. 68 (1979) 673-684.

[3] H.S. Huang, R.D. Schoenwald, J.L. Lach, Corneal penetration behavior of beta-blocking agents II: Assessment of barrier contributions, J. Pharm. Sci. 72 (1983) 1272-1279.

[4] E.M. Del Amo, A. Urtti, Current and future ophthalmic drug delivery systems. A shift to the posterior segment, Drug Discov. Today 13 (2008) 135-143.

[5] K.S. Vellonen, E.M. Soini, E.M. Del Amo, A. Urtti, Prediction of Ocular Drug Distribution from Systemic Blood Circulation, Mol. Pharm. 13 (2016) 2906-2911.

[6] International Transporter Consortium, K.M. Giacomini, S.M. Huang, D.J. Tweedie, L.Z. Benet, K.L. Brouwer, X. Chu, A. Dahlin, R. Evers, V. Fischer, K.M. Hillgren, K.A. Hoffmaster, T. Ishikawa, D. Keppler, R.B. Kim, C.A. Lee, M. Niemi, J.W. Polli, Y. Sugiyama, P.W. Swaan, J.A. Ware, S.H. Wright, S.W. Yee, M.J. Zamek-Gliszczynski, L. Zhang, Membrane transporters in drug development, Nat. Rev. Drug Discov. 9 (2010) 215-236.

[7] European Medicines Agency, Guideline on the investigation of drug interactions, (2012) .

[8] U.S. Department of Health and Human Services, Food and Drug Administration, Drug Interaction Studies Study Design, Data Analysis, Implications

for Dosing, and Labeling

Recommendations, (2012) .

[9] L. Lin, S.W. Yee, R.B. Kim, K.M. Giacomini, SLC transporters as therapeutic targets: emerging opportunities, Nat. Rev. Drug Discov. 14 (2015) 543-560.

[10] E. Perland, R. Fredriksson, Classification Systems of Secondary Active Transporters, Trends Pharmacol. Sci. 38 (2017) 305-315.

[11] Y. Shitara, Clinical importance of OATP1B1 and OATP1B3 in drug-drug interactions, Drug Metab. Pharmacokinet. 26 (2011) 220-227.

[12] P. Matsson, L.A. Fenu, P. Lundquist, J.R. Wisniewski, M. Kansy, P. Artursson, Quantifying the impact of transporters on cellular drug permeability, Trends Pharmacol. Sci. 36 (2015) 255-262.

[13] K. Sugano, M. Kansy, P. Artursson, A. Avdeef, S. Bendels, L. Di, G.F. Ecker, B. Faller, H. Fischer, G. Gerebtzoff, H. Lennernaes, F. Senner, Coexistence of passive and carrier-mediated processes in drug transport, Nat. Rev. Drug Discov. 9 (2010) 597-614. 
[14] C. Vogel, E.M. Marcotte, Insights into the regulation of protein abundance from proteomic and transcriptomic analyses, Nat. Rev. Genet. 13 (2012) 227-232.

[15] S. Ohtsuki, Y. Uchida, Y. Kubo, T. Terasaki, Quantitative targeted absolute proteomics-based ADME research as a new path to drug discovery and development: methodology, advantages, strategy, and prospects, J. Pharm. Sci. 100 (2011) 3547-3559.

[16] K.S. Vellonen, E. Mannermaa, H. Turner, M. Hakli, J.M. Wolosin, T. Tervo, P. Honkakoski, A. Urtti, Effluxing ABC transporters in human corneal epithelium, J. Pharm. Sci. 99 (2010) 1087-1098.

[17] J.W. Sieg, J.R. Robinson, Mechanistic studies on transcorneal permeation of pilocarpine, J. Pharm. Sci. 65 (1976) 1816-1822.

[18] E. Toropainen, V.P. Ranta, K.S. Vellonen, J. Palmgren, A. Talvitie, M. Laavola, P. Suhonen, K.M. Hamalainen, S. Auriola, A. Urtti, Paracellular and passive transcellular permeability in immortalized human corneal epithelial cell culture model, Eur. J. Pharm. Sci. 20 (2003) 99-106.

[19] I. Ahmed, R.D. Gokhale, M.V. Shah, T.F. Patton, Physicochemical determinants of drug diffusion across the conjunctiva, sclera, and cornea, J. Pharm. Sci. 76 (1987) 583-586.

[20] S. Dey, J. Patel, B.S. Anand, B. Jain-Vakkalagadda, P. Kaliki, D. Pal, V. Ganapathy, A.K. Mitra, Molecular evidence and functional expression of P-glycoprotein (MDR1) in human and rabbit cornea and corneal epithelial cell lines, Invest. Ophthalmol. Vis. Sci. 44 (2003) 2909-2918.

[21] J. Verstraelen, S. Reichl, Expression analysis of MDR1, BCRP and MRP3 transporter proteins in different in vitro and ex vivo cornea models for drug absorption studies, Int. J. Pharm. 441 (2013) 765-775.

[22] A. Urtti, L. Salminen, O. Miinalainen, Systemic absorption of ocular pilocarpine is modified by polymer matrices, Int J Pharm 23 (1985) 147-161.

[23] S. Hariharan, S. Gunda, G.P. Mishra, D. Pal, A.K. Mitra, Enhanced corneal absorption of erythromycin by modulating P-glycoprotein and MRP mediated efflux with corticosteroids, Pharm. Res. 26 (2009) 1270-1282.

[24] J. Verstraelen, S. Reichl, Multidrug resistance-associated protein (MRP1, 2, 4 and 5) expression in human corneal cell culture models and animal corneal tissue, Mol. Pharm. 11 (2014) 2160-2171.

[25] P.K. Karla, T.L. Quinn, B.L. Herndon, P. Thomas, D. Pal, A. Mitra, Expression of multidrug resistance associated protein 5 (MRP5) on cornea and its role in drug efflux, J. Ocul. Pharmacol. Ther. 25 (2009) 121-132.

[26] U. Becker, C. Ehrhardt, N. Daum, C. Baldes, U.F. Schaefer, K.W. Ruprecht, K.J. Kim, C.M. Lehr, Expression of ABC-transporters in human corneal tissue and the transformed cell line, HCE-T, J. Ocul. Pharmacol. Ther. 23 (2007) 172-181.

[27] A. Dahlin, E. Geier, S.L. Stocker, C.D. Cropp, E. Grigorenko, M. Bloomer, J. Siegenthaler, L. Xu, A.S. Basile, D.D. Tang-Liu, K.M. Giacomini, Gene expression profiling of transporters in the solute carrier and ATP-binding cassette superfamilies in human eye substructures, Mol. Pharm. 10 (2013) 650-663. 
[28] M. Morita, N. Fujita, A. Takahashi, E.R. Nam, S. Yui, C.S. Chung, N. Kawahara, H.Y. Lin, K. Tsuzuki, T. Nakagawa, R. Nishimura, Evaluation of ABCG2 and p63 expression in canine cornea and cultivated corneal epithelial cells, Vet. Ophthalmol. 18 (2015) 59-68.

[29] P.K. Karla, D. Pal, A.K. Mitra, Molecular evidence and functional expression of multidrug resistance associated protein (MRP) in rabbit corneal epithelial cells, Exp. Eye Res. 84 (2007) 53-60.

[30] R.M. Pelis, M. Shahidullah, S. Ghosh, M. Coca-Prados, S.H. Wright, N.A. Delamere, Localization of multidrug resistance-associated protein 2 in the nonpigmented ciliary epithelium of the eye, J. Pharmacol. Exp. Ther. 329 (2009) 479-485.

[31] B. Li, M.S. Lee, R.S. Lee, P.J. Donaldson, J.C. Lim, Characterization of glutathione uptake, synthesis, and efflux pathways in the epithelium and endothelium of the rat cornea, Cornea 31 (2012) 1304-1312.

[32] J. Nirmal, S.B. Singh, N.R. Biswas, V. Thavaraj, R.V. Azad, T. Velpandian, Potential pharmacokinetic role of organic cation transporters in modulating the transcorneal penetration of its substrates administered topically, Eye (Lond) 27 (2013) 1196-1203.

[33] T. Zhang, C.D. Xiang, D. Gale, S. Carreiro, E.Y. Wu, E.Y. Zhang, Drug transporter and cytochrome P450 mRNA expression in human ocular barriers: implications for ocular drug disposition, Drug Metab. Dispos. 36 (2008) 1300-1307.

[34] K.S. Vellonen, M. Hakli, N. Merezhinskaya, T. Tervo, P. Honkakoski, A. Urtti, Monocarboxylate transport in human corneal epithelium and cell lines, Eur. J. Pharm. Sci. 39 (2010) 241-247.

[35] S. Katragadda, R.S. Talluri, D. Pal, A.K. Mitra, Identification and characterization of a Na+-dependent neutral amino acid transporter, ASCT1, in rabbit corneal epithelial cell culture and rabbit cornea, Curr. Eye Res. 30 (2005) 989-1002.

[36] B. Jain-Vakkalagadda, S. Dey, D. Pal, A.K. Mitra, Identification and functional characterization of a Na+independent large neutral amino acid transporter, LAT1, in human and rabbit cornea, Invest. Ophthalmol. Vis. Sci. 44 (2003) 2919-2927.

[37] B. Jain-Vakkalagadda, D. Pal, S. Gunda, Y. Nashed, V. Ganapathy, A.K. Mitra, Identification of a Natdependent cationic and neutral amino acid transporter, $\mathrm{B}(0,+)$, in human and rabbit cornea, Mol. Pharm. 1 (2004) 338-346.

[38] S. Majumdar, S. Gunda, A. Mitra, Functional expression of a sodium dependent nucleoside transporter on rabbit cornea: Role in corneal permeation of acyclovir and idoxuridine, Curr. Eye Res. 26 (2003) 175-183.

[39] S. Gunda, S. Hariharan, A.K. Mitra, Corneal absorption and anterior chamber pharmacokinetics of dipeptide monoester prodrugs of ganciclovir (GCV): in vivo comparative evaluation of these prodrugs with ValGCV and GCV in rabbits, J. Ocul. Pharmacol. Ther. 22 (2006) 465-476.

[40] S. Katragadda, R.S. Talluri, A.K. Mitra, Modulation of P-glycoprotein-mediated efflux by prodrug derivatization: an approach involving peptide transporter-mediated influx across rabbit cornea, J. Ocul. Pharmacol. Ther. 22 (2006) 110-120. 
[41] V.P. Ranta, E. Mannermaa, K. Lummepuro, A. Subrizi, A. Laukkanen, M. Antopolsky, L. Murtomaki, M. Hornof, A. Urtti, Barrier analysis of periocular drug delivery to the posterior segment, J. Control. Release 148 (2010) 42-48.

[42] P. Saha, J.J. Yang, V.H. Lee, Existence of a p-glycoprotein drug efflux pump in cultured rabbit conjunctival epithelial cells, Invest. Ophthalmol. Vis. Sci. 39 (1998) 1221-1226.

[43] J.J. Yang, K.J. Kim, V.H. Lee, Role of P-glycoprotein in restricting propranolol transport in cultured rabbit conjunctival epithelial cell layers, Pharm. Res. 17 (2000) 533-538.

[44] J.J. Yang, D.K. Ann, R. Kannan, V.H. Lee, Multidrug resistance protein 1 (MRP1) in rabbit conjunctival epithelial cells: its effect on drug efflux and its regulation by adenoviral infection, Pharm. Res. 24 (2007) 14901500.

[45] H. Ueda, Y. Horibe, K.J. Kim, V.H. Lee, Functional characterization of organic cation drug transport in the pigmented rabbit conjunctiva, Invest. Ophthalmol. Vis. Sci. 41 (2000) 870-876.

[46] S.K. Basu, I.S. Haworth, M.B. Bolger, V.H. Lee, Proton-driven dipeptide uptake in primary cultured rabbit conjunctival epithelial cells, Invest. Ophthalmol. Vis. Sci. 39 (1998) 2365-2373.

[47] S. Hariharan, K.G. Janoria, S. Gunda, X. Zhu, D. Pal, A.K. Mitra, Identification and functional expression of a carrier-mediated riboflavin transport system on rabbit corneal epithelium, Curr. Eye Res. 31 (2006) 811-824.

[48] H. Kidron, K.S. Vellonen, E.M. del Amo, A. Tissari, A. Urtti, Prediction of the corneal permeability of druglike compounds, Pharm. Res. 27 (2010) 1398-1407.

[49] E. Ramsay, M. Ruponen, T. Picardat, U. Tengvall, M. Tuomainen, S. Auriola, E. Toropainen, A. Urtti, E.M. Del Amo, Impact of Chemical Structure on Conjunctival Drug Permeability: Adopting Porcine Conjunctiva and Cassette Dosing for Construction of In Silico Model, J. Pharm. Sci. (2017) .

[50] A.M. Tonjum, Movement of horseradish peroxidase in the cornea, sclera and the anterior uvea, Acta Ophthalmol. (Copenh) 55 (1977) 771-780.

[51] J. Cunha-Vaz, The blood-ocular barriers, Surv. Ophthalmol. 23 (1979) 279-296.

[52] G. Raviola, E. Raviola, Intercellular junctions in the ciliary epithelium, Invest. Ophthalmol. Vis. Sci. 17 (1978) 958-981.

[53] J. Lee, R.M. Pelis, Drug Transport by the Blood-Aqueous Humor Barrier of the Eye, Drug Metab. Dispos. 44 (2016) 1675-1681.

[54] S. Fujii, C. Setoguchi, K. Kawazu, K. Hosoya, Impact of P-glycoprotein on blood-retinal barrier permeability: comparison of blood-aqueous humor and blood-brain barrier using mdr1a knockout rats, Invest. Ophthalmol. Vis. Sci. 55 (2014) 4650-4658.

[55] T. Kajikawa, H.K. Mishima, T. Murakami, M. Takano, Role of P-glycoprotein in distribution of rhodamine 123 into aqueous humor in rabbits, Curr. Eye Res. 18 (1999) 240-246. 
[56] S. Fujii, C. Setoguchi, K. Kawazu, K. Hosoya, Functional Characterization of Carrier-Mediated Transport of Pravastatin across the Blood-Retinal Barrier in Rats, Drug Metab. Dispos. 43 (2015) 1956-1959.

[57] B. Gao, B. Stieger, B. Noe, J.M. Fritschy, P.J. Meier, Localization of the organic anion transporting polypeptide 2 (Oatp2) in capillary endothelium and choroid plexus epithelium of rat brain, J. Histochem. Cytochem. 47 (1999) 1255-1264.

[58] V. Cattori, J.E. van Montfoort, B. Stieger, L. Landmann, D.K. Meijer, K.H. Winterhalter, P.J. Meier, B. Hagenbuch, Localization of organic anion transporting polypeptide 4 (Oatp4) in rat liver and comparison of its substrate specificity with Oatp1, Oatp2 and Oatp3, Pflugers Arch. 443 (2001) 188-195.

[59] B. Gao, R.D. Huber, A. Wenzel, S.R. Vavricka, M.G. Ismair, C. Reme, P.J. Meier, Localization of organic anion transporting polypeptides in the rat and human ciliary body epithelium, Exp. Eye Res. 80 (2005) 61-72.

[60] M. Kondo, M. Araie, Movement of carboxyfluorescein across the isolated rabbit iris-ciliary body, Curr. Eye Res. 13 (1994) 251-255.

[61] J. Lee, M. Shahidullah, A. Hotchkiss, M. Coca-Prados, N.A. Delamere, R.M. Pelis, A renal-like organic anion transport system in the ciliary epithelium of the bovine and human eye, Mol. Pharmacol. 87 (2015) 697-705.

[62] B. Gao, S.R. Vavricka, P.J. Meier, B. Stieger, Differential cellular expression of organic anion transporting peptides OATP1A2 and OATP2B1 in the human retina and brain: implications for carrier-mediated transport of neuropeptides and neurosteriods in the CNS, Pflugers Arch. 467 (2015) 1481-1493.

[63] A. Ito, K. Yamaguchi, T. Onogawa, M. Unno, T. Suzuki, T. Nishio, T. Suzuki, H. Sasano, T. Abe, M. Tamai, Distribution of organic anion-transporting polypeptide 2 (oatp2) and oatp3 in the rat retina, Invest.

Ophthalmol. Vis. Sci. 43 (2002) 858-863.

[64] M. Tomi, M. Mori, M. Tachikawa, K. Katayama, T. Terasaki, K. Hosoya, L-type amino acid transporter 1mediated L-leucine transport at the inner blood-retinal barrier, Invest. Ophthalmol. Vis. Sci. 46 (2005) 25222530 .

[65] D.Z. Gerhart, R.L. Leino, L.R. Drewes, Distribution of monocarboxylate transporters MCT1 and MCT2 in rat retina, Neuroscience 92 (1999) 367-375.

[66] G. Chidlow, J.P. Wood, M. Graham, N.N. Osborne, Expression of monocarboxylate transporters in rat ocular tissues, Am. J. Physiol. Cell. Physiol. 288 (2005) C416-28.

[67] L. Bergersen, E. Johannsson, M.L. Veruki, E.A. Nagelhus, A. Halestrap, O.M. Sejersted, O.P. Ottersen, Cellular and subcellular expression of monocarboxylate transporters in the pigment epithelium and retina of the rat, Neuroscience 90 (1999) 319-331.

[68] H. Steuer, A. Jaworski, B. Elger, M. Kaussmann, J. Keldenich, H. Schneider, D. Stoll, B. Schlosshauer, Functional characterization and comparison of the outer blood-retina barrier and the blood-brain barrier, Invest. Ophthalmol. Vis. Sci. 46 (2005) 1047-1053. 
[69] L. Pelkonen, K. Sato, M. Reinisalo, H. Kidron, M. Tachikawa, M. Watanabe, Y. Uchida, A. Urtti, T. Terasaki, LC-MS/MS Based Quantitation of ABC and SLC Transporter Proteins in Plasma Membranes of Cultured Primary Human Retinal Pigment Epithelium Cells and Immortalized ARPE19 Cell Line, Mol. Pharm. 14 (2017) 605-613.

[70] H. Chapy, B. Saubamea, N. Tournier, F. Bourasset, F. Behar-Cohen, X. Decleves, J.M. Scherrmann, S. Cisternino, Blood-brain and retinal barriers show dissimilar $A B C$ transporter impacts and concealed effect of $\mathrm{P}$ glycoprotein on a novel verapamil influx carrier, Br. J. Pharmacol. 173 (2016) 497-510.

[71] R. Toda, K. Kawazu, M. Oyabu, T. Miyazaki, Y. Kiuchi, Comparison of drug permeabilities across the bloodretinal barrier, blood-aqueous humor barrier, and blood-brain barrier, J. Pharm. Sci. 100 (2011) 3904-3911.

[72] S. Senthilkumari, T. Velpandian, N.R. Biswas, N. Sonali, S. Ghose, Evaluation of the impact of P-glycoprotein (P-gp) drug efflux transporter blockade on the systemic and ocular disposition of P-gp substrate, J. Ocul. Pharmacol. Ther. 24 (2008) 290-300.

[73] K. Hippalgaonkar, R. Srirangam, B. Avula, I.A. Khan, S. Majumdar, Interaction between topically and systemically coadministered P-glycoprotein substrates/inhibitors: effect on vitreal kinetics, Drug Metab. Dispos. 38 (2010) 1790-1797.

[74] H. Steuer, A. Jaworski, B. Elger, M. Kaussmann, J. Keldenich, H. Schneider, D. Stoll, B. Schlosshauer, Functional characterization and comparison of the outer blood-retina barrier and the blood-brain barrier, Invest. Ophthalmol. Vis. Sci. 46 (2005) 1047-1053.

[75] M. Bauer, R. Karch, N. Tournier, S. Cisternino, W. Wadsak, M. Hacker, P. Marhofer, M. Zeitlinger, O. Langer, Assessment of P-glycoprotein Transport Activity at the Human Blood-Retinal Barrier with (R)-11C-verapamil PET, J. Nucl. Med. (2016) .

[76] N.P. Blair, M.M. Rusin, Blood-retinal barrier permeability to carboxyfluorescein and fluorescein in monkeys, Graefes Arch. Clin. Exp. Ophthalmol. 224 (1986) 419-422.

[77] J.G. Cunha-Vaz, D.M. Maurice, The active transport of fluorescein by the retinal vessels and the retina, J. Physiol. 191 (1967) 467-486.

[78] Y. Oguro, Y. Tsukahara, I. Saito, T. Kondo, Estimation of the permeability of the blood-retinal barrier in normal individuals, Invest. Ophthalmol. Vis. Sci. 26 (1985) 969-976.

[79] J. Nirmal, T. Velpandian, S.B. Singh, N.R. Biswas, R. Azad, V. Thavaraj, G. Mittal, A. Bhatnagar, S. Ghose, Evaluation of the functional importance of organic cation transporters on the ocular disposition of its intravitreally injected substrate in rabbits, Curr. Eye Res. 37 (2012) 1127-1135.

[80] M. Tachikawa, K. Murakami, P.M. Martin, K. Hosoya, V. Ganapathy, Retinal transfer of nicotinate by H+ monocarboxylate transporter at the inner blood-retinal barrier, Microvasc. Res. 82 (2011) 385-390.

[81] M. Tachikawa, Y. Takeda, M. Tomi, K. Hosoya, Involvement of OCTN2 in the transport of acetyl-L-carnitine across the inner blood-retinal barrier, Invest. Ophthalmol. Vis. Sci. 51 (2010) 430-436. 
[82] L. Pelkonen, K. Sato, M. Reinisalo, H. Kidron, M. Tachikawa, M. Watanabe, Y. Uchida, A. Urtti, T. Terasaki, LC-MS/MS Based Quantitation of ABC and SLC Transporter Proteins in Plasma Membranes of Cultured Primary Human Retinal Pigment Epithelium Cells and Immortalized ARPE19 Cell Line, Mol. Pharm. (2017) .

[83] Y. Uchida, S. Ohtsuki, Y. Katsukura, C. Ikeda, T. Suzuki, J. Kamiie, T. Terasaki, Quantitative targeted absolute proteomics of human blood-brain barrier transporters and receptors, J. Neurochem. 117 (2011) 333-345.

[84] C. Durairaj, J.C. Shah, S. Senapati, U.B. Kompella, Prediction of vitreal half-life based on drug physicochemical properties: quantitative structure-pharmacokinetic relationships (QSPKR), Pharm. Res. 26 (2009) 1236-1260.

[85] H. Kidron, E.M. Del Amo, K.S. Vellonen, A. Urtti, Prediction of the vitreal half-life of small molecular druglike compounds, Pharm. Res. 29 (2012) 3302-3311.

[86] E.M. del Amo, K.S. Vellonen, H. Kidron, A. Urtti, Intravitreal clearance and volume of distribution of compounds in rabbits: In silico prediction and pharmacokinetic simulations for drug development, Eur. J. Pharm. Biopharm. 95 (2015) 215-226.

[87] K.S. Vellonen, E.M. Soini, E.M. Del Amo, A. Urtti, Prediction of Ocular Drug Distribution from Systemic Blood Circulation, Mol. Pharm. 13 (2016) 2906-2911.

[88] E.M. Del Amo, A.K. Rimpela, E. Heikkinen, O.K. Kari, E. Ramsay, T. Lajunen, M. Schmitt, L. Pelkonen, M. Bhattacharya, D. Richardson, A. Subrizi, T. Turunen, M. Reinisalo, J. Itkonen, E. Toropainen, M. Casteleijn, H. Kidron, M. Antopolsky, K.S. Vellonen, M. Ruponen, A. Urtti, Pharmacokinetic aspects of retinal drug delivery, Prog. Retin. Eye Res. 57 (2017) 134-185.

[89] P. Tanna, R.W. Strauss, K. Fujinami, M. Michaelides, Stargardt disease: clinical features, molecular genetics, animal models and therapeutic options, Br. J. Ophthalmol. 101 (2017) 25-30.

[90] D.P. Germain, Pseudoxanthoma elasticum, Orphanet J. Rare Dis. 12 (2017) 85-017-0639-8.

[91] G.L. Vilas, S.K. Loganathan, J. Liu, A.K. Riau, J.D. Young, J.S. Mehta, E.N. Vithana, J.R. Casey, Transmembrane water-flux through SLC4A11: a route defective in genetic corneal diseases, Hum. Mol. Genet. 22 (2013) 4579-4590.

[92] S.P. Patel, M.D. Parker, SLC4A11 and the Pathophysiology of Congenital Hereditary Endothelial Dystrophy, Biomed. Res. Int. 2015 (2015) 475392.

[93] B.W. Iliff, S.A. Riazuddin, J.D. Gottsch, The genetics of Fuchs' corneal dystrophy, Expert Rev. Ophthalmol. 7 (2012) 363-375.

[94] M. Niemi, Transporter pharmacogenetics and statin toxicity, Clin. Pharmacol. Ther. 87 (2010) 130-133.

[95] K.K. Filipski, R.H. Mathijssen, T.S. Mikkelsen, A.H. Schinkel, A. Sparreboom, Contribution of organic cation transporter 2 (OCT2) to cisplatin-induced nephrotoxicity, Clin. Pharmacol. Ther. 86 (2009) 396-402. 
[96] L.C. Gao, D. Wang, F.Q. Liu, Z.Y. Huang, H.G. Huang, G.H. Wang, X. Chen, Q.Z. Shi, L. Hong, L.P. Wu, J. Tang, Influence of PTGS1, PTGFR, and MRP4 genetic variants on intraocular pressure response to latanoprost in Chinese primary open-angle glaucoma patients, Eur. J. Clin. Pharmacol. 71 (2015) 43-50.

[97] P. Zhang, B. Jiang, L. Xie, W. Huang, PTGFR and SLCO2A1 Gene Polymorphisms Determine Intraocular Pressure Response to Latanoprost in Han Chinese Patients with Glaucoma, Curr. Eye Res. 41 (2016) 1561-1565.

[98] H. Liu, Z.K. Yang, Y. Li, W.J. Zhang, Y.T. Wang, X.C. Duan, ABCB1 variants confer susceptibility to primary open-angle glaucoma and predict individual differences to latanoprost treatment, Biomed. Pharmacother. 80 (2016) 115-120.

[99] C.A. McCarty, R. Berg, R. Patchett, R.A. Wilke, J.K. Burmester, Lack of association between polymorphisms in the prostaglandin F2alpha receptor and solute carrier organic anion transporter family $2 \mathrm{~A} 1$ genes and intraocular pressure response to prostaglandin analogs, Ophthalmic Genet. 33 (2012) 74-76.

[100] Y. Tanaka, A. Manabe, H. Fukushima, R. Suzuki, H. Nakadate, K. Kondoh, K. Nakamura, K. Koh, T. Fukushima, M. Tsuchida, K. Koike, N. Kiyokawa, E. Noguchi, R. Sumazaki, T. Komiyama, Multidrug resistance protein 4 (MRP4) polymorphisms impact the 6-mercaptopurine dose tolerance during maintenance therapy in Japanese childhood acute lymphoblastic leukemia, Pharmacogenomics J. 15 (2015) 380-384.

[101] N. Simon, A. Marsot, E. Villard, S. Choquet, H.X. Khe, N. Zahr, P. Lechat, V. Leblond, J.S. Hulot, Impact of $A B C C 2$ polymorphisms on high-dose methotrexate pharmacokinetics in patients with lymphoid malignancy, Pharmacogenomics J. 13 (2013) 507-513.

[102] P. Ranganathan, R. Culverhouse, S. Marsh, A. Mody, T.J. Scott-Horton, R. Brasington, A. Joseph, V. Reddy, S. Eisen, H.L. McLeod, Methotrexate (MTX) pathway gene polymorphisms and their effects on MTX toxicity in Caucasian and African American patients with rheumatoid arthritis, J. Rheumatol. 35 (2008) 572-579.

[103] J.S. Hulot, E. Villard, A. Maguy, V. Morel, L. Mir, I. Tostivint, D. William-Faltaos, C. Fernandez, S. Hatem, G. Deray, M. Komajda, V. Leblond, P. Lechat, A mutation in the drug transporter gene ABCC2 associated with impaired methotrexate elimination, Pharmacogenet Genomics 15 (2005) 277-285.

[104] J.L. Giglia, M.J. White, A.J. Hart, J.J. Toro, C.O. Freytes, C.C. Holt, Y. Cai, S.M. Williams, S.J. Brandt, A single nucleotide polymorphism in SLC7A5 is associated with gastrointestinal toxicity after high-dose melphalan and autologous stem cell transplantation for multiple myeloma, Biol. Blood Marrow Transplant. 20 (2014) 10141020.

[105] A. Kuhne, R. Kaiser, M. Schirmer, U. Heider, S. Muhlke, W. Niere, T. Overbeck, K. Hohloch, L. Trumper, 0. Sezer, J. Brockmoller, Genetic polymorphisms in the amino acid transporters LAT1 and LAT2 in relation to the pharmacokinetics and side effects of melphalan, Pharmacogenet Genomics 17 (2007) 505-517.

[106] E. Mannermaa, K.S. Vellonen, A. Urtti, Drug transport in corneal epithelium and blood-retina barrier: emerging role of transporters in ocular pharmacokinetics, Adv. Drug Deliv. Rev. 58 (2006) 1136-1163.

[107] S. Dauchy, F. Dutheil, R.J. Weaver, F. Chassoux, C. Daumas-Duport, P.O. Couraud, J.M. Scherrmann, I. De Waziers, X. Decleves, ABC transporters, cytochromes P450 and their main transcription factors: expression at the human blood-brain barrier, J. Neurochem. 107 (2008) 1518-1528. 
[108] K. Kawazu, K. Yamada, M. Nakamura, A. Ota, Characterization of cyclosporin A transport in cultured rabbit corneal epithelial cells: P-glycoprotein transport activity and binding to cyclophilin, Invest. Ophthalmol. Vis. Sci. 40 (1999) 1738-1744.

[109] M. Barot, M.R. Gokulgandhi, D. Pal, A.K. Mitra, Mitochondrial localization of P-glycoprotein and peptide transporters in corneal epithelial cells--novel strategies for intracellular drug targeting, Exp. Eye Res. 106 (2013) 47-54.

[110] K. Kawazu, S. Fujii, K. Yamada, K. Shinomiya, O. Katsuta, Y. Horibe, Characterization of monocarboxylate uptake and immunohistochemical demonstration of monocarboxylate transporters in cultured rabbit corneal epithelial cells, J. Pharm. Pharmacol. 65 (2013) 328-336.

[111] G. Chidlow, J.P. Wood, M. Graham, N.N. Osborne, Expression of monocarboxylate transporters in rat ocular tissues, Am. J. Physiol. Cell. Physiol. 288 (2005) C416-28.

[112] M.E. Kraft, H. Glaeser, K. Mandery, J. Konig, D. Auge, M.F. Fromm, U. Schlotzer-Schrehardt, U. WelgeLussen, F.E. Kruse, O. Zolk, The prostaglandin transporter OATP2A1 is expressed in human ocular tissues and transports the antiglaucoma prostanoid latanoprost, Invest. Ophthalmol. Vis. Sci. 51 (2010) 2504-2511.

[113] A. Ito, K. Yamaguchi, H. Tomita, T. Suzuki, T. Onogawa, T. Sato, H. Mizutamari, T. Mikkaichi, T. Nishio, T. Suzuki, M. Unno, H. Sasano, T. Abe, M. Tamai, Distribution of rat organic anion transporting polypeptide-E (oatp-E) in the rat eye, Invest. Ophthalmol. Vis. Sci. 44 (2003) 4877-4884.

[114] Q. Garrett, S. Xu, P.A. Simmons, J. Vehige, J.L. Flanagan, M.D. Willcox, Expression and localization of carnitine/organic cation transporter OCTN1 and OCTN2 in ocular epithelium, Invest. Ophthalmol. Vis. Sci. 49 (2008) 4844-4849.

[115] M.P. Langford, P. Redmond, R. Chanis, R.P. Misra, T.B. Redens, Glutamate, excitatory amino acid transporters, Xc- antiporter, glutamine synthetase, and gamma-glutamyltranspeptidase in human corneal epithelium, Curr. Eye Res. 35 (2010) 202-211.

[116] J. Wu, J.J. Zhang, H. Koppel, T.J. Jacob, P-glycoprotein regulates a volume-activated chloride current in bovine non-pigmented ciliary epithelial cells, J. Physiol. 491 ( Pt 3) (1996) 743-755.

[117] J.A. Holash, P.A. Stewart, The relationship of astrocyte-like cells to the vessels that contribute to the blood-ocular barriers, Brain Res. 629 (1993) 218-224.

[118] R.O. Schlingemann, P. Hofman, J. Klooster, H.G. Blaauwgeers, R. Van der Gaag, G.F. Vrensen, Ciliary muscle capillaries have blood-tissue barrier characteristics, Exp. Eye Res. 66 (1998) 747-754.

[119] B.G. Kennedy, N.J. Mangini, P-glycoprotein expression in human retinal pigment epithelium, Mol. Vis. 8 (2002) 422-430.

[120] M. Tagami, S. Kusuhara, S. Honda, Y. Tsukahara, A. Negi, Expression of ATP-binding cassette transporters at the inner blood-retinal barrier in a neonatal mouse model of oxygen-induced retinopathy, Brain Res. 1283 (2009) 186-193. 
[121] K. Hosoya, A. Makihara, Y. Tsujikawa, D. Yoneyama, S. Mori, T. Terasaki, S. Akanuma, M. Tomi, M. Tachikawa, Roles of inner blood-retinal barrier organic anion transporter 3 in the vitreous/retina-to-blood efflux transport of p-aminohippuric acid, benzylpenicillin, and 6-mercaptopurine, J. Pharmacol. Exp. Ther. 329 (2009) 87-93.

[122] L.W. Maines, D.A. Antonetti, E.B. Wolpert, C.D. Smith, Evaluation of the role of P-glycoprotein in the uptake of paroxetine, clozapine, phenytoin and carbamazapine by bovine retinal endothelial cells, Neuropharmacology 49 (2005) 610-617.

[123] E. Mannermaa, K.S. Vellonen, T. Ryhanen, K. Kokkonen, V.P. Ranta, K. Kaarniranta, A. Urtti, Efflux protein expression in human retinal pigment epithelium cell lines, Pharm. Res. 26 (2009) 1785-1791.

[124] J.P. Gnana-Prakasam, S.K. Reddy, R. Veeranan-Karmegam, S.B. Smith, P.M. Martin, V. Ganapathy, Polarized distribution of heme transporters in retinal pigment epithelium and their regulation in the ironoverload disease hemochromatosis, Invest. Ophthalmol. Vis. Sci. 52 (2011) 9279-9286.

[125] T. Asashima, S. Hori, S. Ohtsuki, M. Tachikawa, M. Watanabe, C. Mukai, S. Kitagaki, N. Miyakoshi, T. Terasaki, ATP-binding cassette transporter G2 mediates the efflux of phototoxins on the luminal membrane of retinal capillary endothelial cells, Pharm. Res. 23 (2006) 1235-1242.

[126] K. Juuti-Uusitalo, H. Vaajasaari, T. Ryhanen, S. Narkilahti, R. Suuronen, E. Mannermaa, K. Kaarniranta, H. Skottman, Efflux protein expression in human stem cell-derived retinal pigment epithelial cells, PLoS One 7 (2012) e30089.

[127] J.V. Aukunuru, G. Sunkara, N. Bandi, W.B. Thoreson, U.B. Kompella, Expression of multidrug resistanceassociated protein (MRP) in human retinal pigment epithelial cells and its interaction with BAPSG, a novel aldose reductase inhibitor, Pharm. Res. 18 (2001) 565-572.

[128] C.M. Szober, S.M. Hauck, K.N. Euler, K.J. Frohlich, C. Alge-Priglinger, M. Ueffing, C.A. Deeg, Profound reorganization of cell surface proteome in equine retinal pigment epithelial cells in response to in vitro culturing, Int. J. Mol. Sci. 13 (2012) 14053-14072.

[129] N.J. Philp, D. Wang, H. Yoon, L.M. Hjelmeland, Polarized expression of monocarboxylate transporters in human retinal pigment epithelium and ARPE-19 cells, Invest. Ophthalmol. Vis. Sci. 44 (2003) 1716-1721.

[130] V.L. Bonilha, S.K. Bhattacharya, K.A. West, J. Sun, J.W. Crabb, M.E. Rayborn, J.G. Hollyfield, Proteomic characterization of isolated retinal pigment epithelium microvilli, Mol. Cell. Proteomics 3 (2004) 1119-1127.

[131] X. Gu, N.J. Neric, J.S. Crabb, J.W. Crabb, S.K. Bhattacharya, M.E. Rayborn, J.G. Hollyfield, V.L. Bonilha, AgeRelated Changes in the Retinal Pigment Epithelium (RPE), PLoS One 7 (2012) e38673.

doi:10.1371/journal.pone.0038673.

[132] N.J. Philp, H. Yoon, E.F. Grollman, Monocarboxylate transporter MCT1 is located in the apical membrane and MCT3 in the basal membrane of rat RPE, Am. J. Physiol. 274 (1998) R1824-8.

[133] G. Chidlow, J.P. Wood, M. Graham, N.N. Osborne, Expression of monocarboxylate transporters in rat ocular tissues, Am. J. Physiol. Cell. Physiol. 288 (2005) C416-28. 
[134] D.Z. Gerhart, R.L. Leino, L.R. Drewes, Distribution of monocarboxylate transporters MCT1 and MCT2 in rat retina, Neuroscience 92 (1999) 367-375.

[135] T. Chan, L. Zhu, M.C. Madigan, K. Wang, W. Shen, M.C. Gillies, F. Zhou, Human organic anion transporting polypeptide 1A2 (OATP1A2) mediates cellular uptake of all-trans-retinol in human retinal pigmented epithelial cells, Br. J. Pharmacol. 172 (2015) 2343-2353.

[136] S. Akanuma, S. Hirose, M. Tachikawa, K. Hosoya, Localization of organic anion transporting polypeptide (Oatp) 1a4 and Oatp1c1 at the rat blood-retinal barrier, Fluids Barriers CNS 10 (2013) 29-8118-10-29.

[137] M.E. Kraft, H. Glaeser, K. Mandery, J. Konig, D. Auge, M.F. Fromm, U. Schlotzer-Schrehardt, U. WelgeLussen, F.E. Kruse, O. Zolk, The prostaglandin transporter OATP2A1 is expressed in human ocular tissues and transports the antiglaucoma prostanoid latanoprost, Invest. Ophthalmol. Vis. Sci. 51 (2010) 2504-2511. 


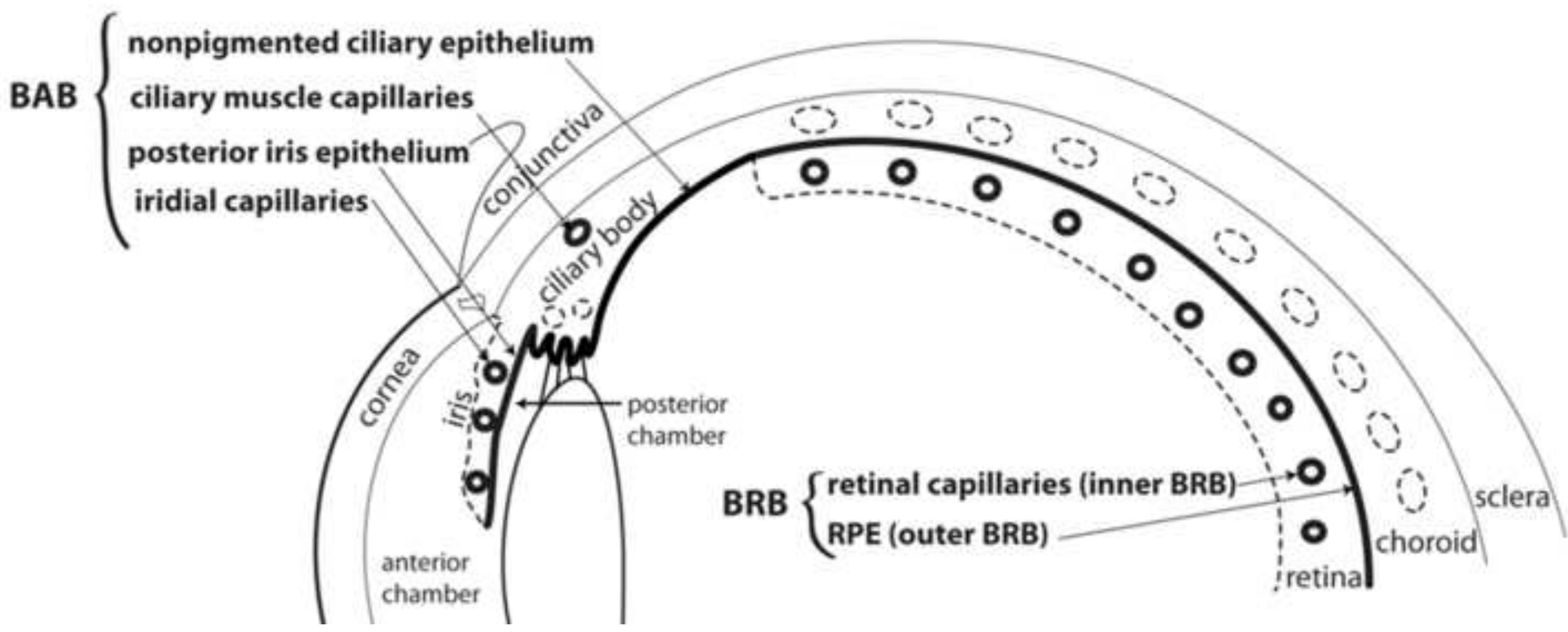




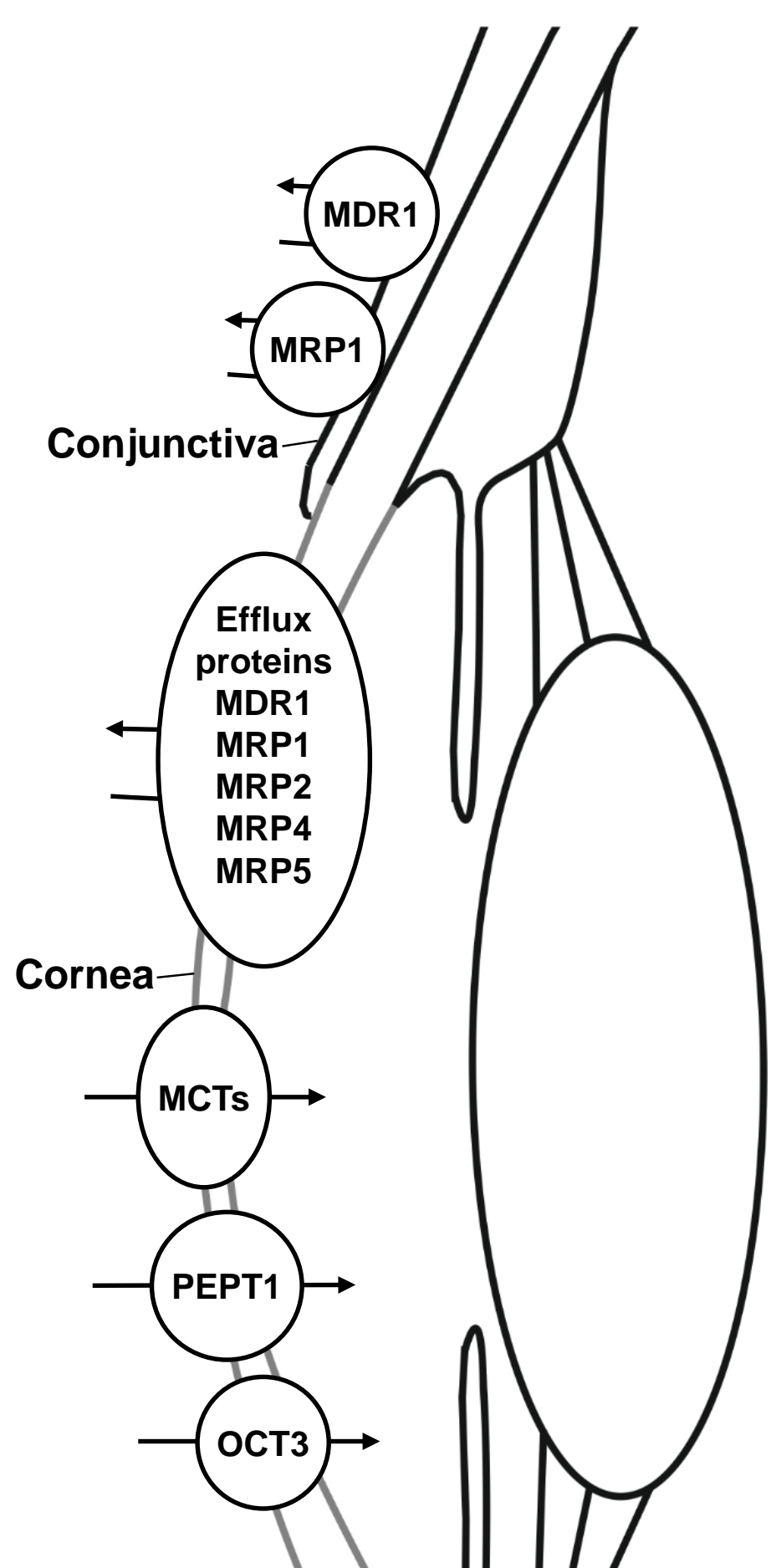


Figure x. Schematic presentation of corneal and conjunctival transporters which protein expression and functionality have been reported in tissue or primary cells. MRP4 function has been reported in porcine cornea, but not in rabbit. For further information, see text and table $X$. 


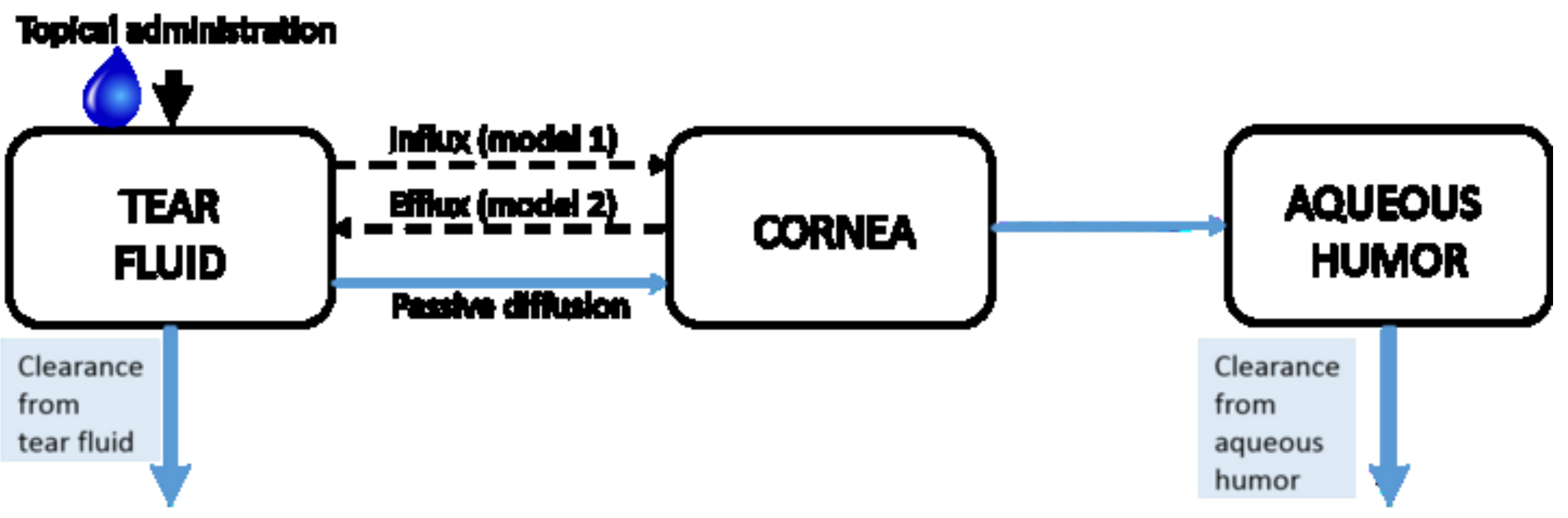


Click here to download high resolution image

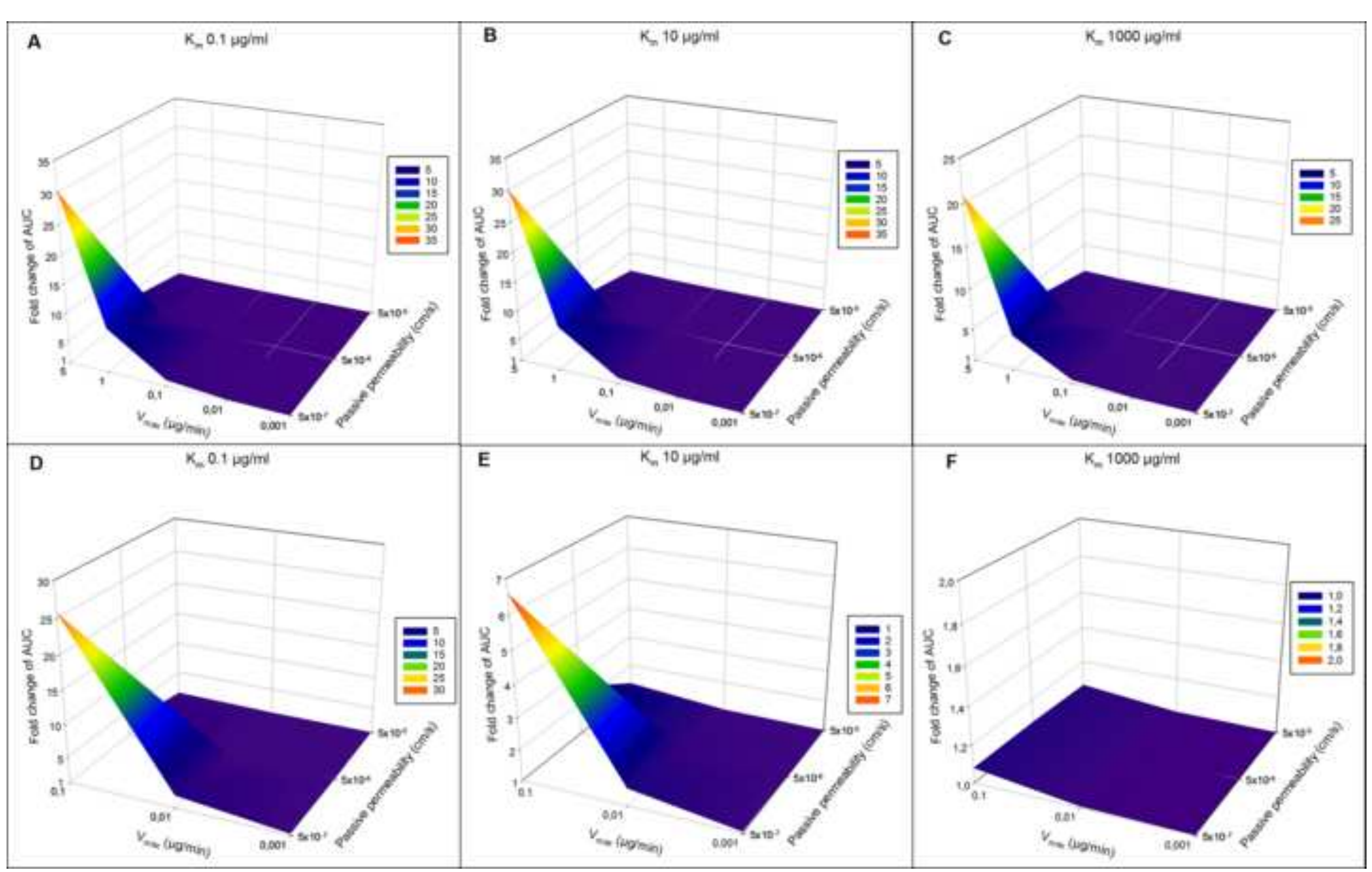


A
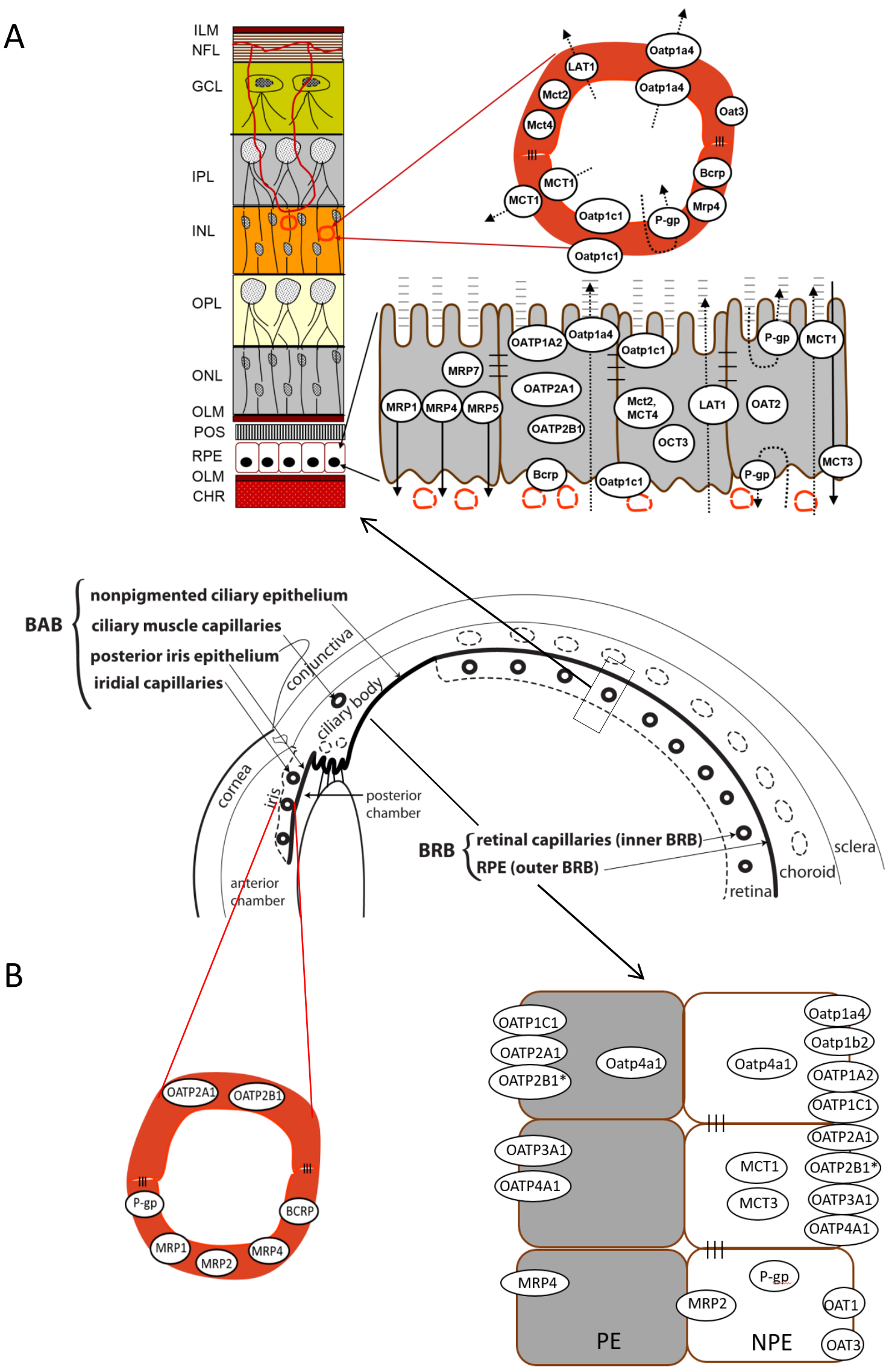
A

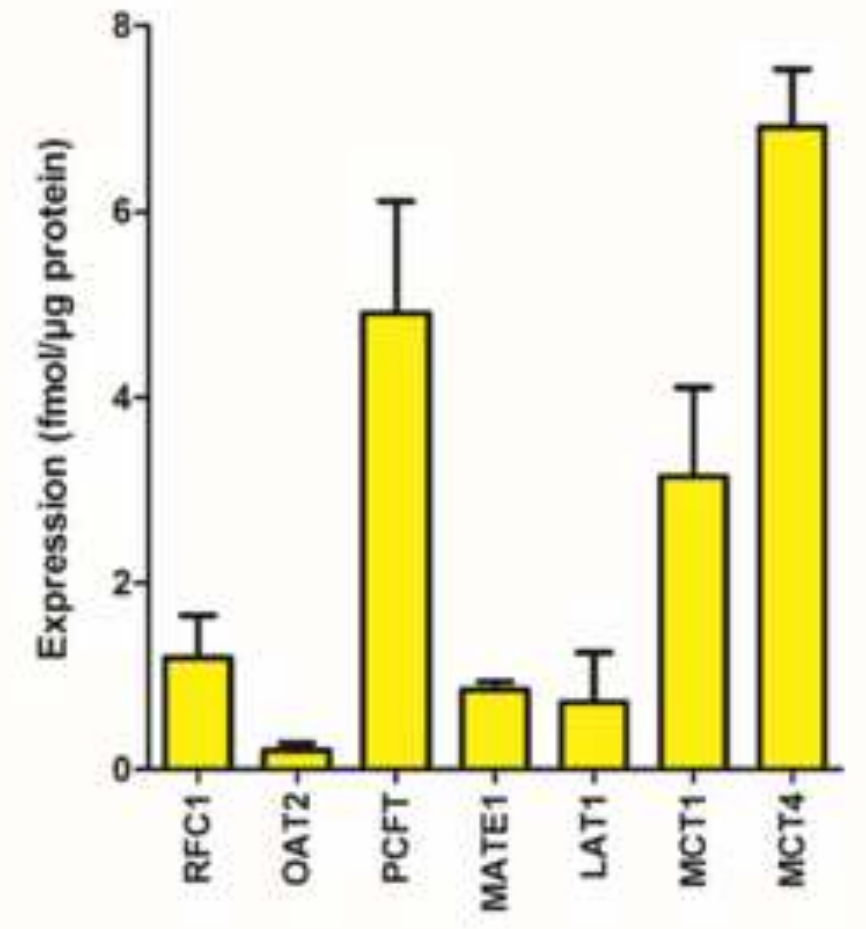

B

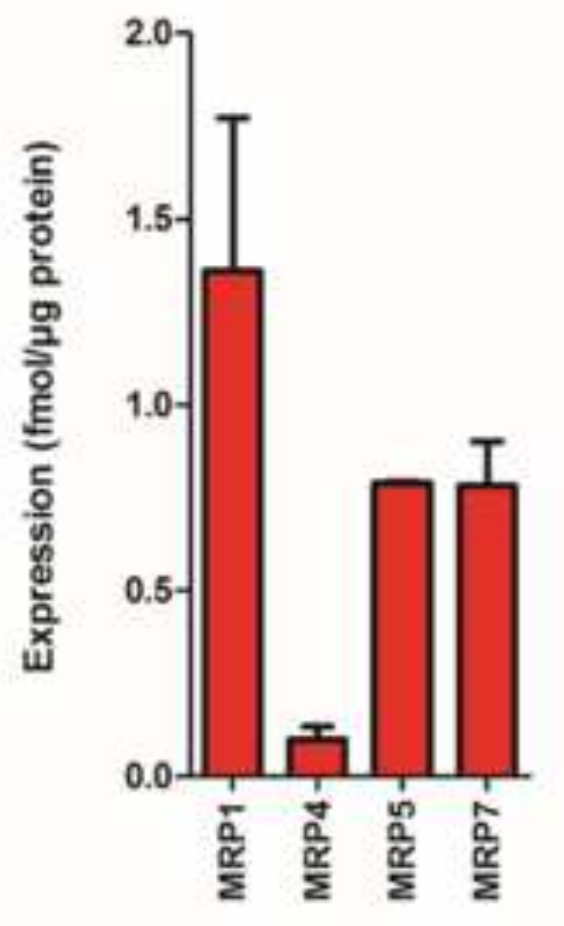

C

\section{Expression below} detection IImitt

P-gp, MPP2, MFP3, MRP6, MRPQ, BCRP, PEPT1, MCT3, OATP1B1, OATP1B3, OCT1, OCT2, OCT3, OCTN2, OAT1, OAT3, OAT4, MATE2, MATE2k 
A

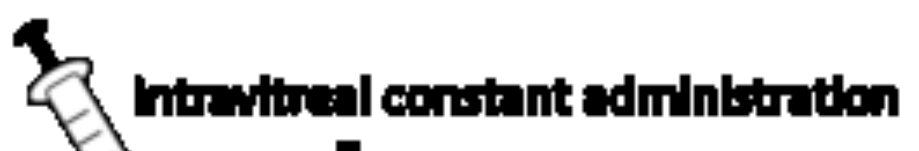

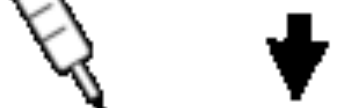

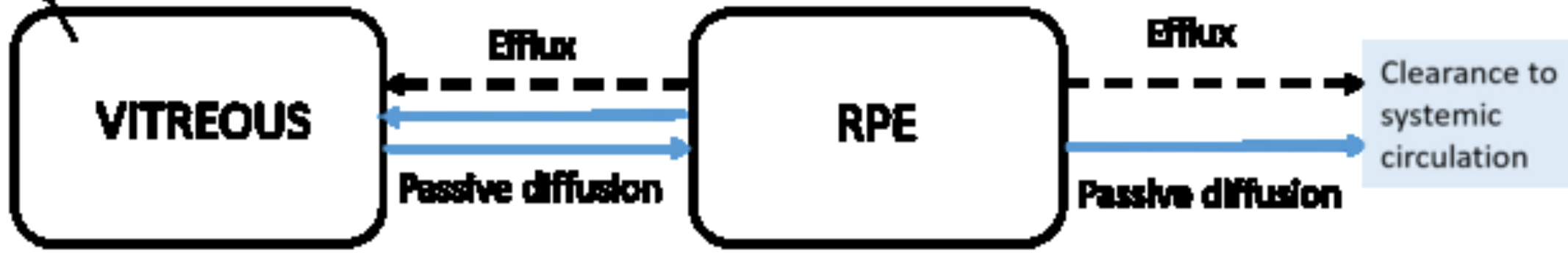

B

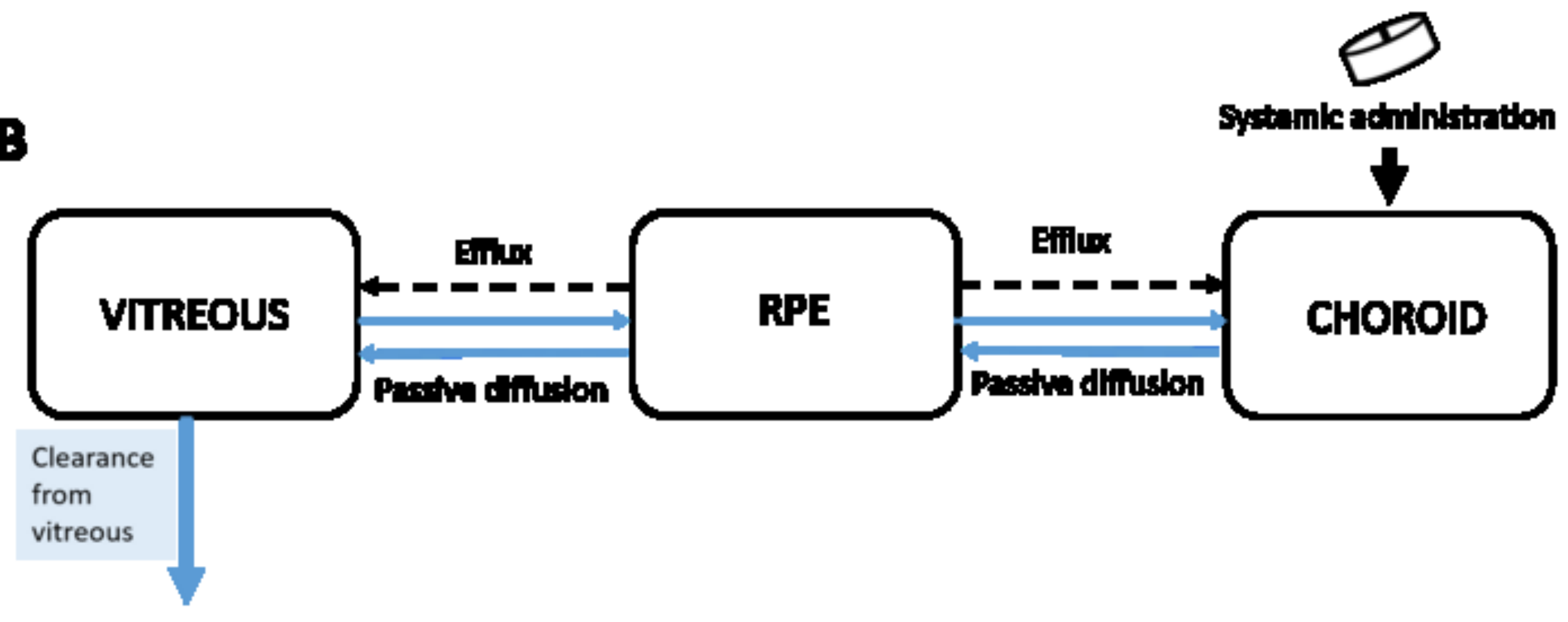




\section{Figure}

Click here to download high resolution image

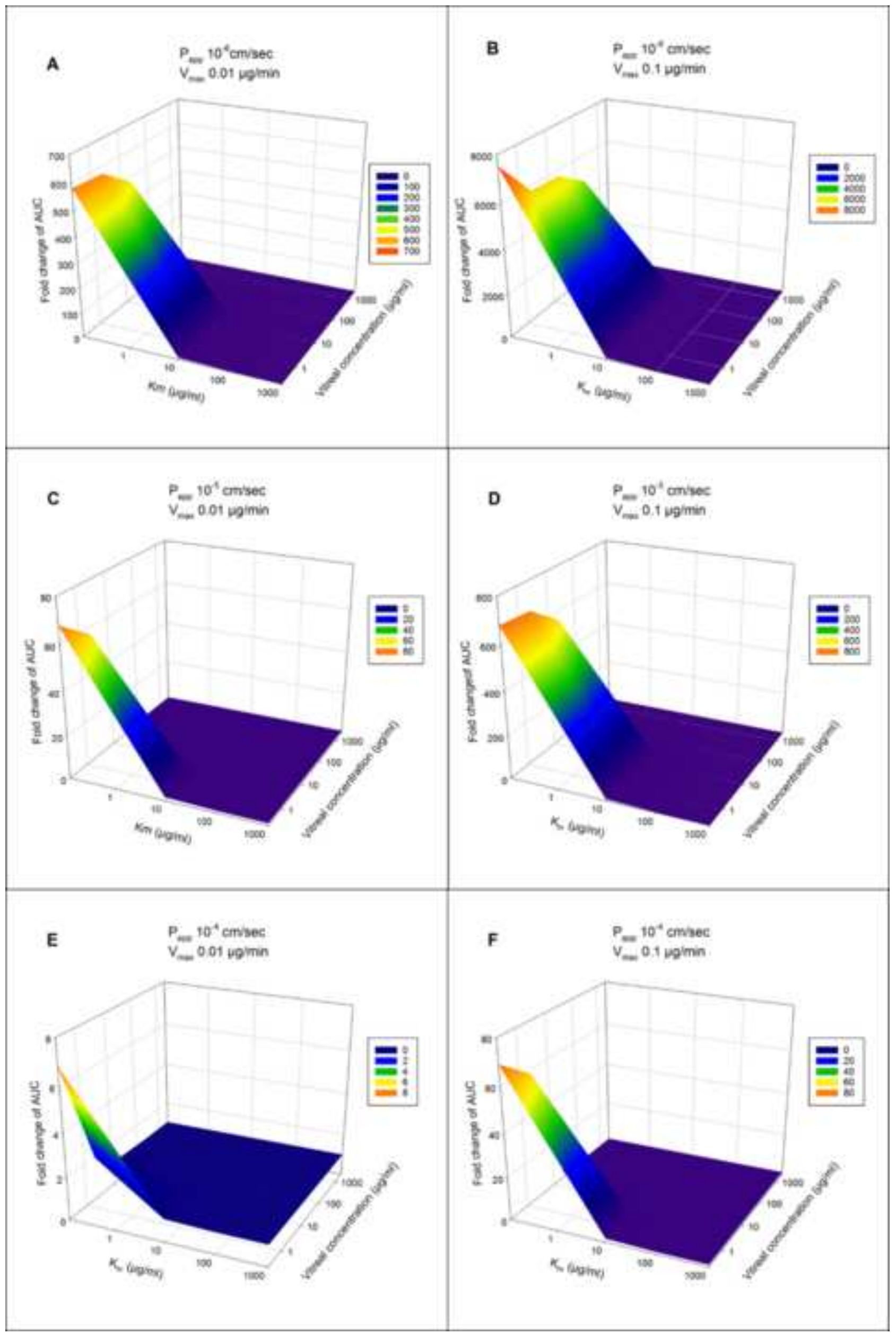




\section{Figure 9
Click here to download high resolution image \\ Click here to download high resolution image}

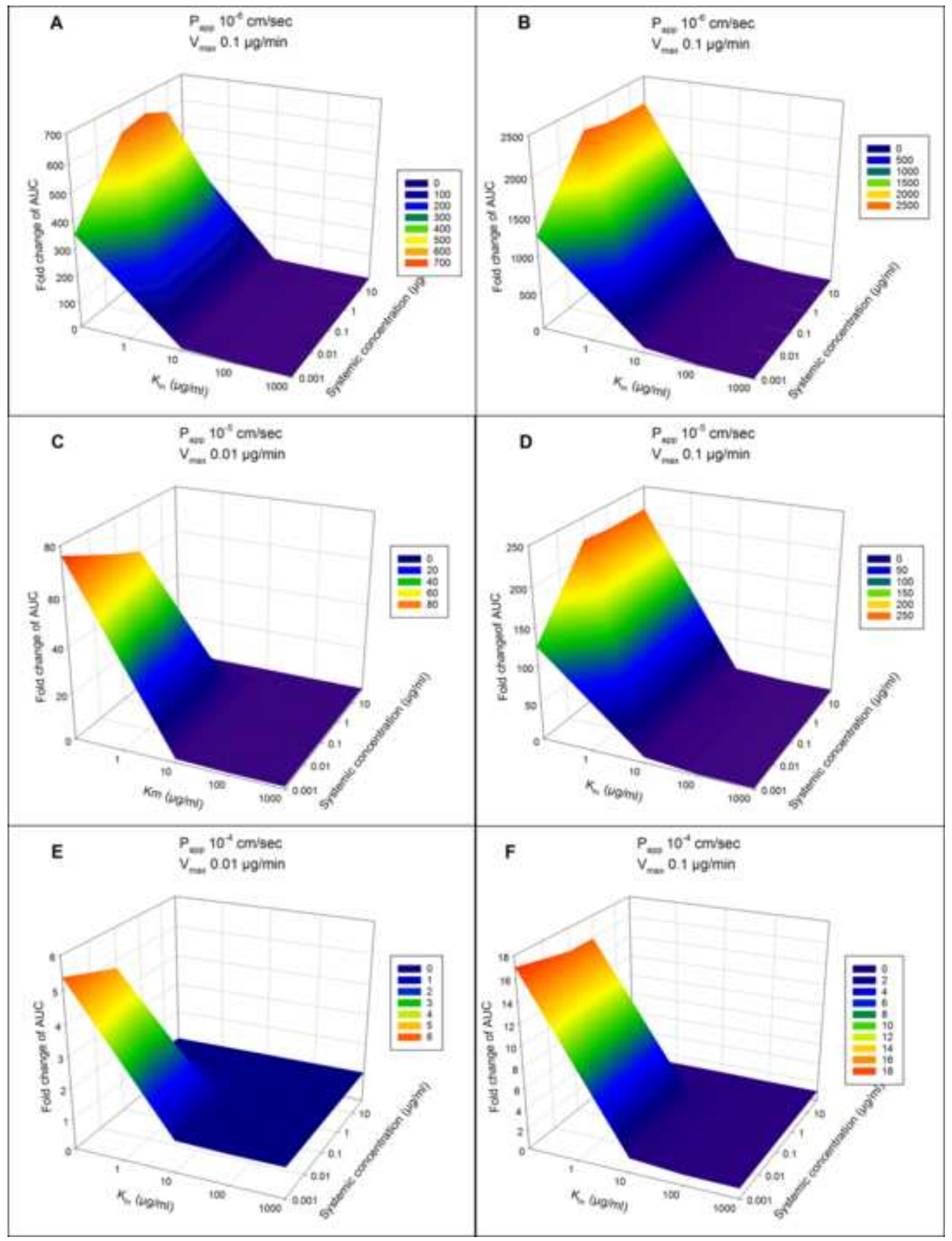




\section{Supplementary material on corneal simulation models}

All simulations were conducted using STELLA v10.0.03 Simulations Software (isee systems, Lebanon, NH, United States) with fourth-order Runge-Kutta algorithm. Cornea model structures are presented in Figures S1 and S2 (models numbered 1-2), and the equations of the models are displayed below the figures. The parameter values with literature references are presented in the Table S1. The simulation time of $360 \mathrm{~min}$ and DT value of 0.02 was used.

Table S1: Parameter values for cornea simulation models

\begin{tabular}{|c|c|c|c|c|}
\hline & Value & Unit & Notes & Reference \\
\hline $\begin{array}{l}\text { Apparent permeability } \\
\left(P_{\text {app }}\right) \text { across cornea }\end{array}$ & $0.00003-0.003$ & $\mathrm{~cm} / \mathrm{min}$ & $\begin{array}{l}\text { Wide range } \\
\text { was selected } \\
\text { to cover } \\
\text { permeability } \\
\text { values of } \\
\text { hydrophilic } \\
\text { and lipophilic } \\
\text { compounds }\end{array}$ & \\
\hline $\begin{array}{l}\text { Clearance across } \\
\text { conjunctiva } \\
\text { (CL_TF_CNJ) }\end{array}$ & 0.0104 & $\mathrm{ml} / \mathrm{min}$ & & (Ahmed et al., 1987) \\
\hline $\begin{array}{l}\text { Clearance from } \\
\text { aqueous humor } \\
\text { (CL_outflow) }\end{array}$ & 0.02 & $\mathrm{ml} / \mathrm{min}$ & & $\begin{array}{l}\text { (Del Amo et al., } \\
\text { 2016; Urtti et al., } \\
\text { 1990) }\end{array}$ \\
\hline $\begin{array}{l}\text { Clearance on tear } \\
\text { turnover (CL_TT) }\end{array}$ & 0.00053 & $\mathrm{ml} / \mathrm{min}$ & & (Chrai et al., 1973) \\
\hline $\begin{array}{l}\text { Rate constant for drug } \\
\text { transfer from cornea } \\
\text { to aqueous humor } \\
\text { (k_D) }\end{array}$ & 0.0179 & $1 / \min$ & & (Ranta et al., 2003) \\
\hline $\begin{array}{l}\text { Rate constant for } \\
\text { drainage (k_drain) }\end{array}$ & 0.545 & $1 / \min$ & & $\begin{array}{l}\text { (Chrai et al., } \\
\text { 1973; Ranta et al., } \\
\text { 2003) }\end{array}$ \\
\hline Surface area of cornea & 1.73 & $\mathrm{~cm}^{2}$ & & (Watsky et al., 1988) \\
\hline Thickness of cornea & 0.004 & $\mathrm{~cm}$ & & $\begin{array}{l}\text { (Maurice and } \\
\text { Mishima, 1984) }\end{array}$ \\
\hline $\begin{array}{l}\text { Volume of cornea } \\
\text { (V_cornea) }\end{array}$ & 0.0692 & $\mathrm{ml}$ & $\begin{array}{l}\text { Surface area } x \\
\text { thickness of } \\
\text { cornea }\end{array}$ & \\
\hline $\begin{array}{l}\text { Volume of the tear } \\
\text { fluid (V_tear_fluid) }\end{array}$ & 0.0075 & $\mathrm{ml}$ & & (Chrai et al., 1973) \\
\hline $\mathbf{V}_{\max }$ & $\begin{array}{l}\text { model } 1 \text { (influx): } \\
0.001-5 \\
\text { model } 2 \text { (efflux): } \\
0.001-0.1\end{array}$ & $\mu \mathrm{g} / \mathrm{min}$ & $\begin{array}{l}\text { corneal } \\
\text { permeability } \\
\text { studies }\end{array}$ & $\begin{array}{l}\text { (Anand and Mitra, } \\
\text { 2002;Hariharan et } \\
\text { al., 2006;Jain- } \\
\text { Vakkalagadda et al., } \\
\text { 2004;Katragadda et } \\
\text { al., 2005) }\end{array}$ \\
\hline $\mathrm{K}_{\mathrm{m}}$ & & $\mu \mathrm{g} / \mathrm{ml}$ & & $\begin{array}{l}\text { (UCSF-FDA } \\
\text { TransPortal } \\
\text { database) }\end{array}$ \\
\hline
\end{tabular}




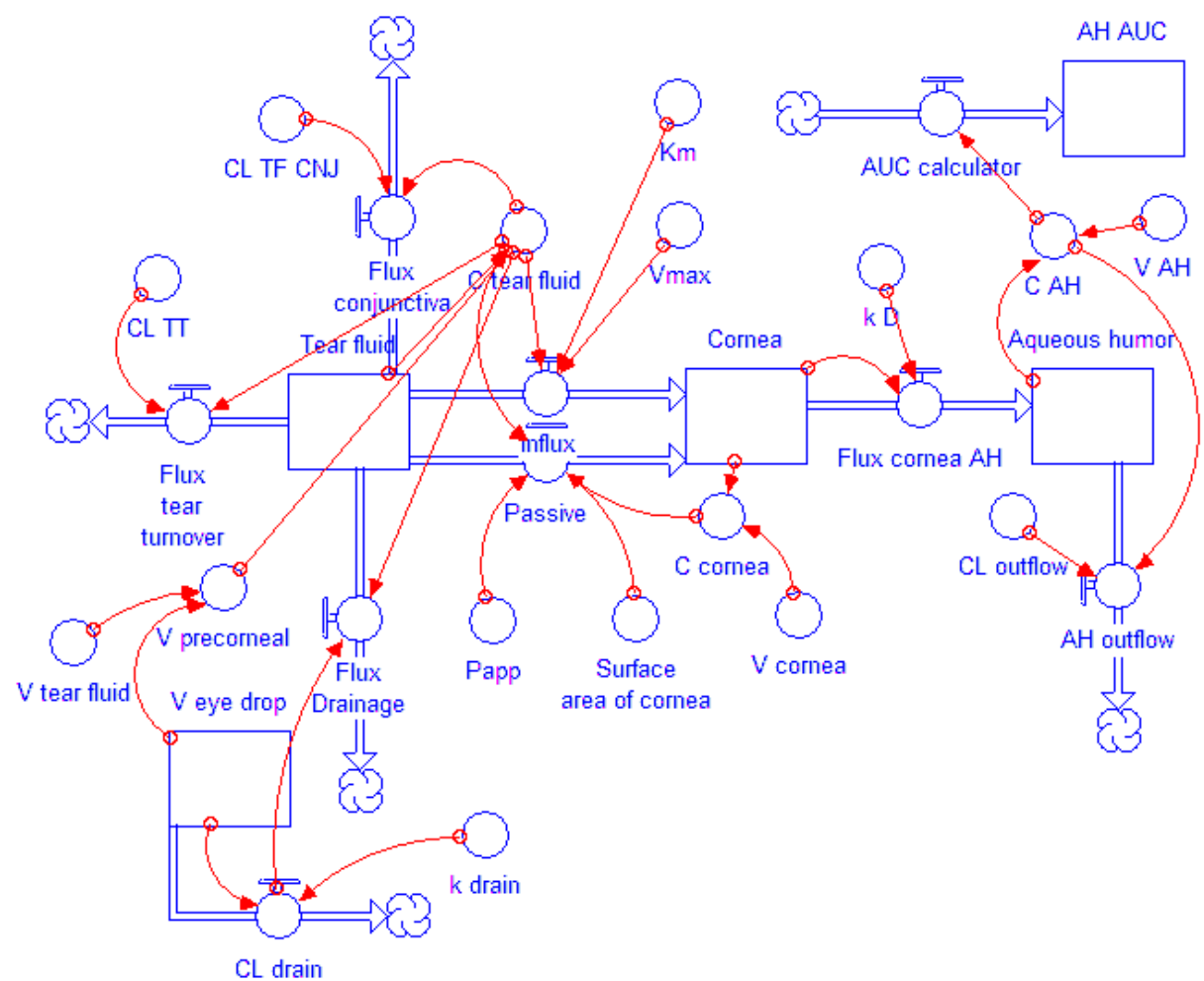

Figure S1. Illustration of the cornea simulation model 1 displaying active influx on the apical surface of the cornea after topical administration.

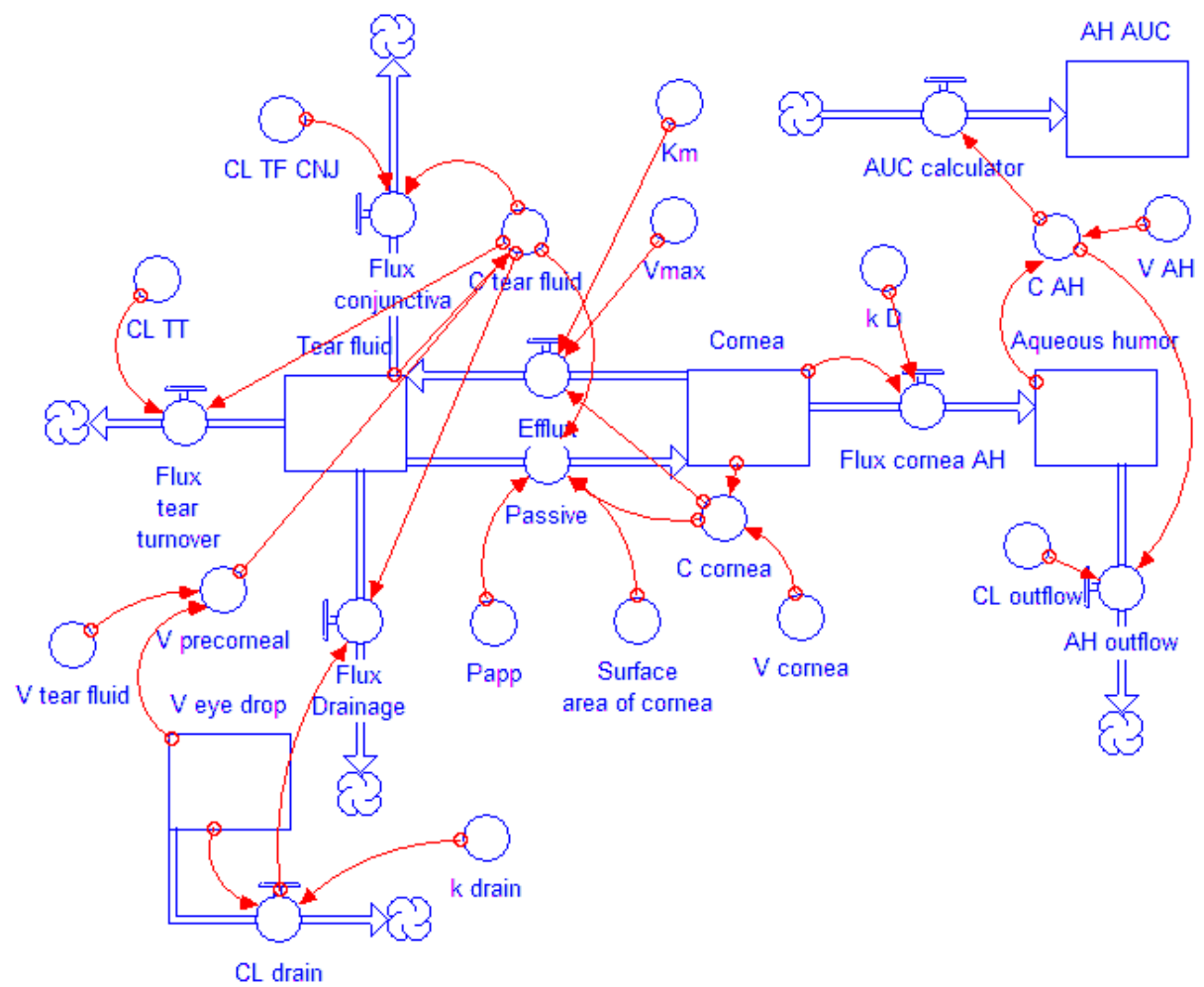

Figure S2. Illustration of the cornea simulation model 2 displaying active efflux on the apical surface of the cornea after topical administration. 


\section{EQUATIONS FOR THE CORNEAL SIMULATION MODEL}

AH_AUC $(\mathrm{t})=\mathrm{AH} \_\mathrm{AUC}(\mathrm{t}-\mathrm{dt})+($ AUC_calculator $) * \mathrm{dt}$

INIT AH_AUC $=0$

\section{INFLOWS:}

AUC_calculator $=C_{-}$AH

Aqueous_humor $(\mathrm{t})=$ Aqueous_humor $(\mathrm{t}-\mathrm{dt})+\left(\right.$ Flux_cornea_AH $-\mathrm{AH} \_$outflow $) * \mathrm{dt}$

INIT Aqueous_humor $=0$

\section{INFLOWS:}

Flux_cornea_AH $=$ Cornea*K_D

\section{OUTFLOWS:}

AH_outflow $=$ CL_outflow ${ }^{*} C \_$AH

Cornea $(\mathrm{t})=$ Cornea $(\mathrm{t}-\mathrm{dt})+($ Passive - Flux_cornea_AH - Efflux $) * \mathrm{dt}$

INIT Cornea $=0$

\section{INFLOWS:}

Passive $=$ Papp $*$ Surface_area_of_cornea*(C_tear_fluid-C_cornea)

Model 1: Influx $=\left(\right.$ mmax $^{*} C_{-}$tear_fluid $) /\left(K m+C_{-}\right.$tear_fluid $)$

\section{OUTFLOWS:}

Flux_cornea_AH = Cornea*K_D

Model 2: Efflux $=\left(\right.$ Vmax ${ }^{*} C_{-}$cornea $) /\left(K m+C_{-}\right.$cornea $)$

Tear_fluid $(\mathrm{t})=$ Tear_fluid $(\mathrm{t}-\mathrm{dt})+($ Efflux - Flux_Drainage - Passive - Flux_conjunctiva - Flux_tear_turnover $)$ * $\mathrm{dt}$

INIT Tear_fluid $=250(\mu \mathrm{g})$

INFLOWS:

Efflux $=\left(\right.$ Vmax ${ }^{*} C_{-}$cornea $) /($Km+C_cornea $)$

\section{OUTFLOWS:}

Flux__Drainage $=\mathrm{CL}_{-}$drain $* C_{-}$tear_fluid

Passive $=$ Papp*Surface__Area_of_Cornea* $\left(C_{-}\right.$tear_fluid-C_cornea $)$

Flux_conjunctiva $=\mathrm{CL} \mathrm{TF}_{-} \mathrm{CNJ}{ }^{*} \mathrm{C}_{-}$tear_fluid

Flux_tear_turnover $=\mathrm{C}_{-}$tear_fluid $* \mathrm{CL} \_\mathrm{TT}$

V_eye_drop $(\mathrm{t})=V_{-}$eye_drop $(\mathrm{t}-\mathrm{dt})+\left(-\mathrm{CL} \_\mathrm{drain}\right) * \mathrm{dt}$

INIT V_eye_drop $=0.025(\mathrm{ml})$

\section{OUTFLOWS:}

$\mathrm{CL}$ drain $=$ k_drain*V_eye_drop

CL_outflow $=0.02(\mathrm{ml} / \mathrm{min})$

CL_TF_CNJ $=0.0104(\mathrm{ml} / \mathrm{min})$

$\mathrm{CL} \_\mathrm{TT}=0.00053(\mathrm{ml} / \mathrm{min})$

C_AH = Aqueous_humor/V_AH

C_cornea $=$ Cornea $/ V_{-}$cornea

C_tear_fluid $=$ Tear_fluid $/ \mathrm{V} \_$precorneal 
$\mathrm{Km}=0.1-1000(\mu \mathrm{g} / \mathrm{ml})$

k_D $=0.0179(1 / \mathrm{min})$

k_drain $=0.545(1 / \mathrm{min})$

Papp $=0.00003-0.003(\mathrm{~cm} / \mathrm{min})$

Surface_area_of_cornea $=1.73\left(\mathrm{~cm}^{2}\right)$

$V \max =0.001-1-5(\mu \mathrm{g} / \mathrm{min})$

$\mathrm{V} \_\mathrm{AH}=0.3(\mathrm{ml})$

$V_{\text {_cornea }}=0.0692(\mathrm{ml})$

V_precorneal $=V_{-}$tear_fluid $+V_{-}$eye_drop

$V_{-}$tear_fluid $=0.0075(\mathrm{ml})$ 


\section{Supplementary material on RPE simulation models}

All simulations were conducted using STELLA v10.0.03 Simulations Software (isee systems, Lebanon, NH, United States) with fourth-order Runge-Kutta algorithm. RPE model structures are presented in Figure S3S6 (models numbered 1-4), and the equations in the models are displayed below each figure. The parameter values with literature references are presented in Table S2.

Table S2. Parameters used in the RPE simulations

\begin{tabular}{|l|l|l|l|l|l|}
\hline & $\begin{array}{l}\text { Model } \\
\text { number }\end{array}$ & Value & Unit & Notes & Reference \\
\hline RPE thickness & $1-4$ & 0.0014 & $\mathrm{~cm}$ & & (Curcio et al., 2011) \\
\hline RPE surface area & $1-4$ & 12.04 & $\mathrm{~cm}^{2}$ & & $\begin{array}{l}\text { (Del Amo and Urtti, } \\
\text { 2015) }\end{array}$ \\
\hline $\begin{array}{l}\text { Volume of the } \\
\text { vitreous }\end{array}$ & $1-2$ & 4 & $\mathrm{ml}$ & & $\begin{array}{l}\text { (Del Amo and Urtti, } \\
\text { 2015) }\end{array}$ \\
\hline $\begin{array}{l}\text { Unbound } \\
\text { concentration in blood } \\
\text { (Cu blood) }\end{array}$ & $1-2$ & $0.001-50$ & $\mu \mathrm{g} / \mathrm{ml}$ & $\begin{array}{l}\text { peak } \\
\text { concentrations } \\
\text { in plasma } \\
\text { (humans) }\end{array}$ & $\begin{array}{l}\text { (Goodman and } \\
\text { Gilman 2001) }\end{array}$ \\
\hline $\begin{array}{l}\text { Concentration in the } \\
\text { vitreous }\end{array}$ & $3-4$ & $0.25-2500$ & $\mu \mathrm{g} / \mathrm{ml}$ & $\begin{array}{l}\text { vitreal } \\
\text { concentrations } \\
\text { (rabbits) }\end{array}$ & $\begin{array}{l}\text { (Del Amo and Urtti, } \\
\text { 2015) }\end{array}$ \\
\hline $\begin{array}{l}\text { Vitreal clearance } \\
\text { Apparent permeability }\end{array}$ & $1-4$ & $6 \times 10^{-4}-6 \times 10^{-6}$ & $\mathrm{~cm} / \mathrm{min}$ & $\begin{array}{l}\text { permeability } \\
\text { across porcine } \\
\text { substrate } \\
\text { RPE-choroid }\end{array}$ & $\begin{array}{l}\text { (Pitkanen et al., } \\
\text { 2005;Steuer et al., } \\
\text { 2005) }\end{array}$ \\
\hline $\mathbf{V}_{\text {max }}$ & $1-2$ & 0.000517 & $\mathrm{ml} / \mathrm{min}$ (Del Amo and Urtti, \\
2015)
\end{tabular}

We used our own data to calculate the total protein amount in the RPE. The calculations were based on the protein amount of human fetal RPE cells per $12.04 \mathrm{~cm}^{2}$ culture area (RPE surface area, Table S1). The ranges for unbound plasma concentrations, vitreal concentrations and Michaelis costant $\left(\mathrm{K}_{\mathrm{m}}\right)$ values were selected based on the realistic values for variety of small molecular weight compounds (Table S1).

The simulation time was $24 \mathrm{~h}$ (1440 $\mathrm{min}$ ) for the systemic administration models and $12 \mathrm{~h}(720 \mathrm{~min})$ for the vitreal administration model displaying time intervals (dt) of 0.05 and $0.04 \mathrm{~min}$, respectively. 


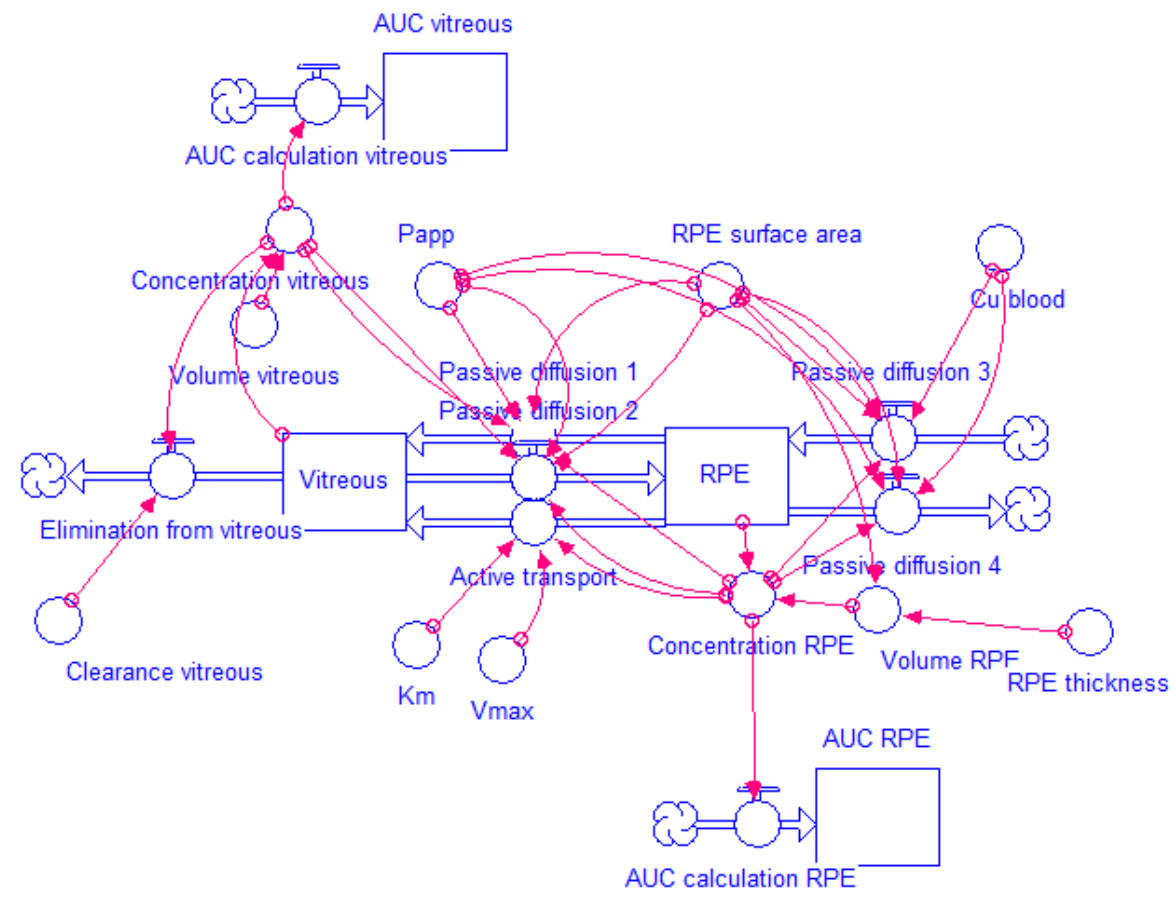

Figure S3. Illustration of the RPE simulation model 1 displaying systemic administration and active efflux on the apical surface of the RPE.

EQUATIONS FOR THE RPE SIMULATION MODEL 1 (systemic administration and apical efflux in the RPE).

AUC_RPE $(t)=$ AUC_RPE $(t-d t)+\left(A U C \_c a l c u l a t i o n \_R P E\right) * d t$

INIT AUC_RPE $=0$

INFLOWS:

AUC_calculation_RPE = Concentration_RPE

AUC_vitreous $(\mathrm{t})=$ AUC_vitreous $(\mathrm{t}-\mathrm{dt})+($ AUC_calculation_vitreous $) * d t$

INIT AUC_vitreous $=0$

INFLOWS:

AUC_calculation_vitreous $=$ Concentration_vitreous

$R P E(t)=R P E(t-d t)+($ Passive_diffusion_3 + Passive_diffusion_2 - Active_transport - Passive_diffusion_1 -

Passive_diffusion_4) $* \mathrm{dt}$

INIT RPE $=0$

INFLOWS:

Passive_diffusion_3 $=\left(\mathrm{Cu} \_\right.$blood-Concentration_RPE $) *$ Papp*RPE_surface_area

Passive_diffusion_2 = (Concentration_vitreous-Concentration_RPE)*Papp*RPE_surface_area

OUTFLOWS:

Active_transport $=$ Vmax ${ }^{*}$ Concentration_RPE $/(\mathrm{Km}+$ Concentration_RPE $)$ 
Passive_diffusion_1 = (Concentration_RPE-Concentration_vitreous) ${ }^{*}$ Papp*RPE_surface_area

Passive_diffusion_4 $=($ Concentration_RPE-Cu_blood $) *$ Papp*RPE_surface_area

Vitreous $(\mathrm{t})=$ Vitreous $(\mathrm{t}$ - $\mathrm{dt})+($ Active_transport + Passive_diffusion_1 - Elimination_from_vitreous Passive_diffusion_2)*dt

INIT Vitreous $=0$

\section{INFLOWS:}

Active_transport $=$ Vmax*Concentration_RPE $/\left(K m+C o n c e n t r a t i o n \_R P E\right)$

Passive_diffusion_1 = (Concentration_RPE-Concentration_vitreous) ${ }^{*}$ Papp*RPE_surface_area

\section{OUTFLOWS:}

Elimination_from_vitreous $=$ Clearance_vitreous*Concentration_vitreous

Passive_diffusion_2 = (Concentration_vitreous-Concentration_RPE) ${ }^{*}$ Papp*RPE_surface_area

Clearance_vitreous $=0.000517 \mathrm{ml} / \mathrm{min}$

Concentration_RPE = RPE/Volume_RPE

Concentration_vitreous = Vitreous/Volume_vitreous

Cu_blood $=0.001-50 \mu \mathrm{g} / \mathrm{ml}$

$\mathrm{Km}=0.1-1000 \mu \mathrm{g} / \mathrm{ml}$

Papp $=0.0006-0.000006 \mathrm{~cm} / \mathrm{min}$

RPE_thickness $=0.0014 \mathrm{~cm}$

Surface_area_RPE $=12.04 \mathrm{~cm}^{2}$

$V_{\max }=0.01-0.1 \mu \mathrm{g} / \mathrm{min}$

Volume_RPE $=$ RPE_thickness*Surface_area_RPE

Volume_vitreous $=4 \mathrm{ml}$ 


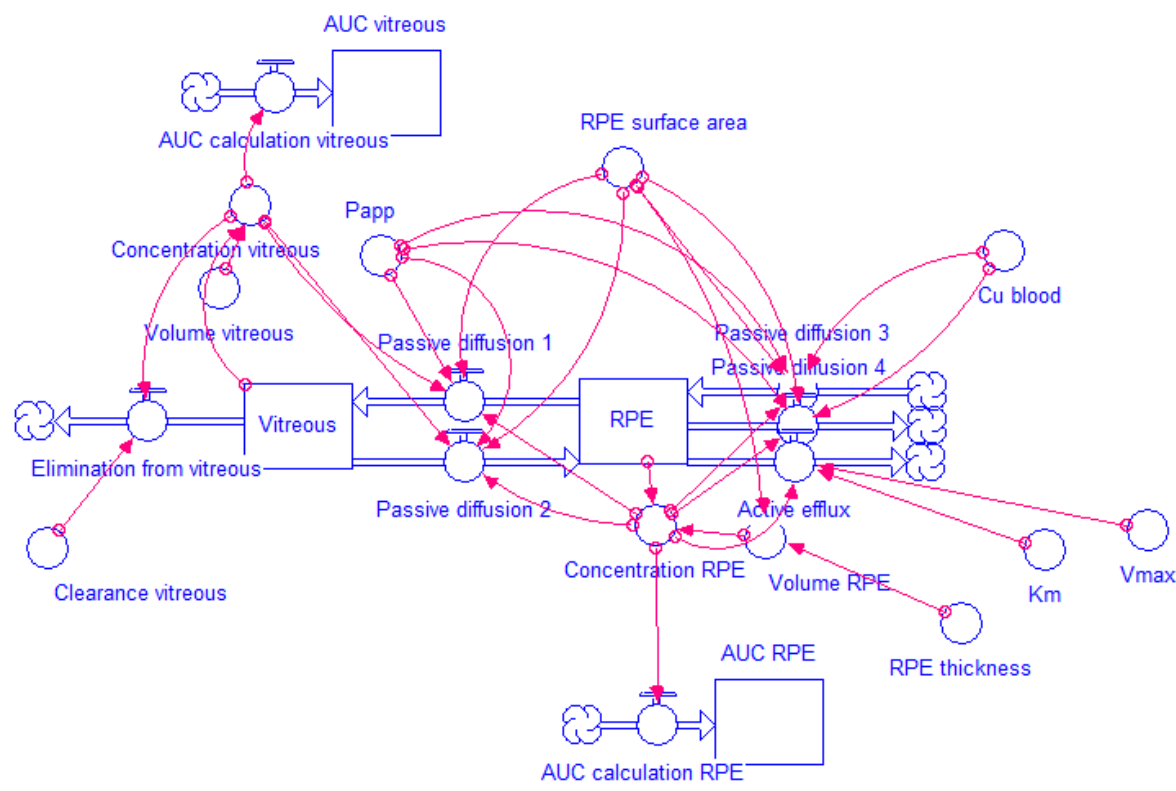

Figure S4. Illustration of the RPE simulation model 2 displaying systemic administration and active efflux on the basolateral surface of the RPE.

EQUATIONS FOR THE RPE SIMULATION MODEL 2 (systemic administration and basolateral efflux in the RPE).

$A U C \_R P E(t)=A U C \_R P E(t-d t)+\left(A U C \_c a l c u l a t i o n \_R P E\right) * d t$

INIT AUC_RPE $=0$

INFLOWS:

AUC_calculation_RPE $=$ Concentration_RPE

AUC_vitreous $(\mathrm{t})=$ AUC_vitreous $(\mathrm{t}-\mathrm{dt})+($ AUC_calculation_vitreous $) * \mathrm{dt}$

INIT AUC_vitreous $=0$

INFLOWS:

AUC_calculation_vitreous $=$ Concentration_vitreous

$\mathrm{RPE}(\mathrm{t})=\mathrm{RPE}(\mathrm{t}-\mathrm{dt})+($ Passive_diffusion_3 + Passive_diffusion_2 - Passive_diffusion_1 - Passive_diffusion_4 Active_efflux) $* d t$

INIT RPE $=0$

\section{INFLOWS:}

Passive_diffusion_3 $=\left(\mathrm{Cu} \_ \text {blood-Concentration_RPE) }\right)^{*}$ Papp*RPE_surface_area

Passive_diffusion_2 = (Concentration_vitreous-Concentration_RPE) $*$ Papp*RPE_surface_area

\section{OUTFLOWS:}

Passive_diffusion_1 = (Concentration_RPE-Concentration_vitreous)*Papp*RPE_surface_area

Passive_diffusion_4 $=($ Concentration_RPE-Cu_blood $) *$ Papp*RPE_surface_area 
Active_efflux $=$ Vmax $*$ Concentration_RPE $/(\mathrm{Km}+$ Concentration_RPE $)$

Vitreous $(t)=$ Vitreous $(t-d t)+($ Passive_diffusion_1 - Elimination_from_vitreous - Passive_diffusion_2 $) * d t$ INIT Vitreous $=0$

\section{INFLOWS:}

Passive_diffusion_1 = (Concentration_RPE-Concentration_vitreous) ${ }^{*}$ Papp*RPE_surface_area

OUTFLOWS:

Elimination_from_vitreous = Clearance_vitreous*Concentration_vitreous

Passive_diffusion_2 =(Concentration_vitreous-Concentration_RPE) ${ }^{*}$ Papp ${ }^{*}$ RPE_surface_area

Clearance_vitreous $=0.000517 \mathrm{ml} / \mathrm{min}$

Concentration_RPE = RPE/Volume_RPE

Concentration_vitreous = Vitreous/Volume_vitreous

Cu_blood $=0.001-50 \mu \mathrm{g} / \mathrm{ml}$

$\mathrm{Km}=0.1-1000 \mu \mathrm{g} / \mathrm{ml}$

Papp $=0.0006-0.000006 \mathrm{~cm} / \mathrm{min}$

RPE_thickness $=0.0014 \mathrm{~cm}$

Surface_area_RPE $=12.04 \mathrm{~cm}^{2}$

$V_{\max }=0.01-0.1 \mu \mathrm{g} / \mathrm{min}$

Volume_RPE $=$ RPE_thickness $*$ Surface_area_RPE

Volume_vitreous $=4 \mathrm{ml}$ 


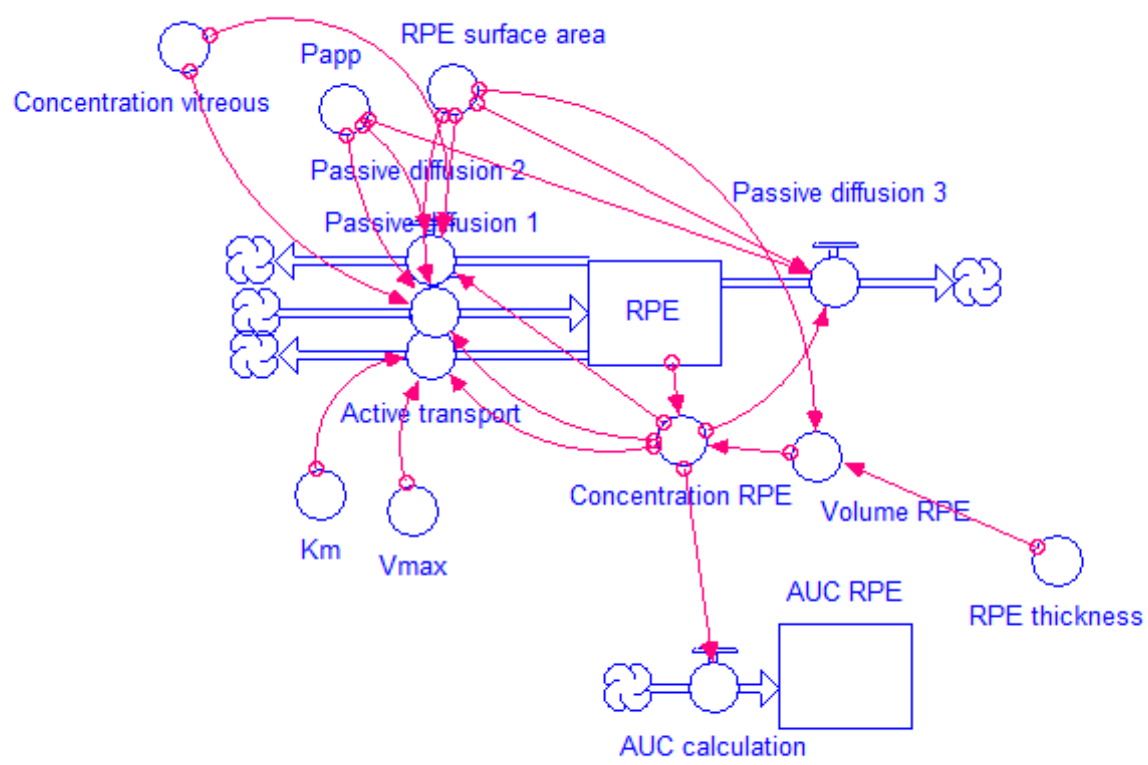

Figure S5. Illustration of the RPE simulation model 3 displaying intravitreal administration and active efflux on the apical surface of the RPE.

EQUATIONS FOR THE RPE SIMULATION MODEL 3 (intravitreal administration and apical efflux in the RPE).

AUC_RPE $(\mathrm{t})=$ AUC_RPE $(\mathrm{t}-\mathrm{dt})+($ AUC_calculation $) * d t$

INIT AUC_RPE $=0$

INFLOWS:

AUC_calculation $=$ Concentration_RPE

$\operatorname{RPE}(\mathrm{t})=\mathrm{RPE}(\mathrm{t}-\mathrm{dt})+($ Passive_diffusion_1 - Passive_diffusion_3 - Active_transport - Passive_diffusion_2 $) * d t$ INIT RPE $=0$

\section{INFLOWS:}

Passive_diffusion_1 = Papp*RPE_surface_area*(Concentration_vitreous-Concentration_RPE)

\section{OUTFLOWS:}

Passive_diffusion_3 $=$ Concentration_RPE*Papp*RPE_surface_area

Active_transport $=$ Vmax ${ }^{*}$ Concentration_RPE $/(\mathrm{Km}+$ Concentration_RPE $)$

Passive_diffusion_2 $=\left(\right.$ Concentration_RPE-Concentration_vitreous) ${ }^{*}$ Papp*RPE_surface_area

Concentration_RPE $=$ RPE/Volume_RPE

Concentration_vitreous $=0.25-2500 \mu \mathrm{g} / \mathrm{ml}$

$\mathrm{Km}=0.1-1000 \mu \mathrm{g} / \mathrm{ml}$

Papp $=0.0006-0.000006 \mathrm{~cm} / \mathrm{min}$ 
RPE_surface_area $=12.04 \mathrm{~cm}^{2}$

RPE_thickness $=0.0014 \mathrm{~cm}$

$V_{\max }=0.01-0.1 \mu \mathrm{g} / \mathrm{min}$

Volume_RPE $=$ RPE_thickness ${ }^{*}$ RPE_surface_area

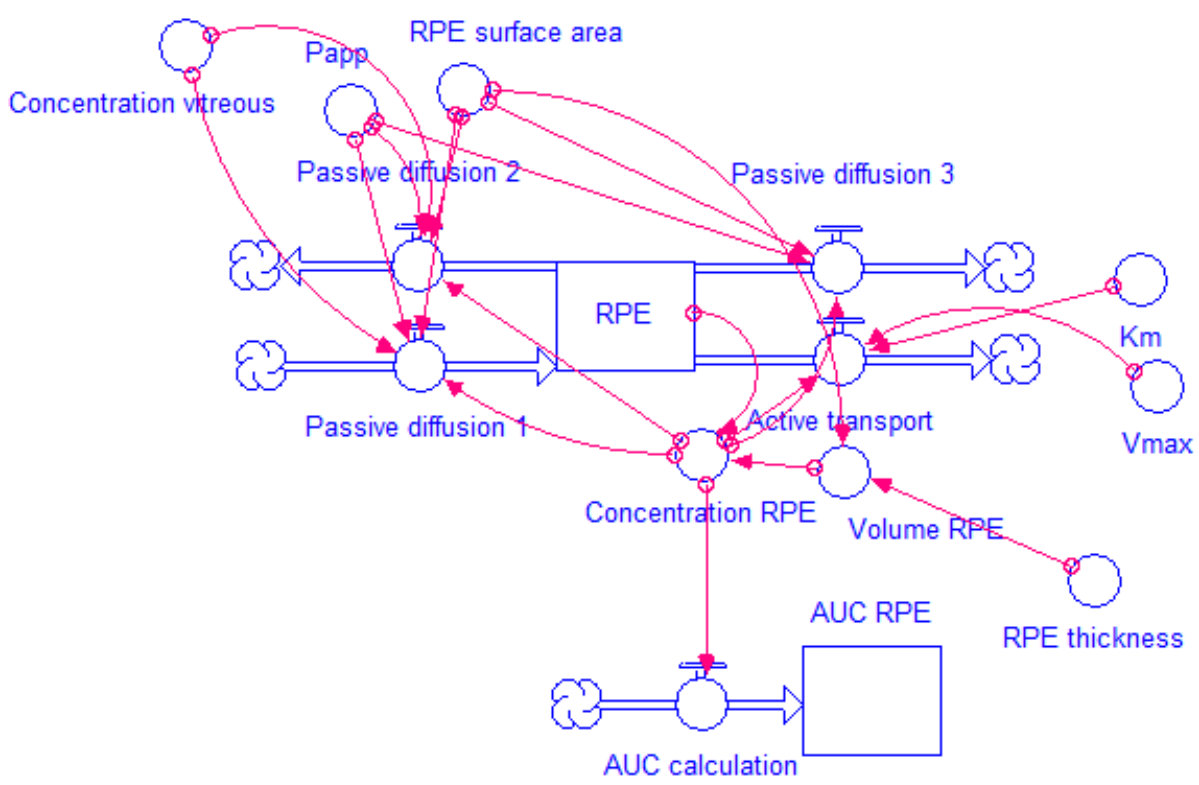

Figure S6. Illustration of the RPE simulation model 4 displaying intravitreal administration and active efflux on the basolateral surface of the RPE.

EQUATIONS FOR THE RPE SIMULATION MODEL 4 (intravitreal administration and basolateral efflux in the RPE).

AUC_RPE $(t)=A U C_{-} R P E(t-d t)+\left(A U C_{-}\right.$calculation $) * d t$

INIT AUC_RPE $=0$

INFLOWS:

AUC_calculation $=$ Concentration_RPE

$\operatorname{RPE}(\mathrm{t})=\mathrm{RPE}(\mathrm{t}-\mathrm{dt})+($ Passive_diffusion_1 - Passive_diffusion_3 - Passive_diffusion_2 - Active_transport $) * \mathrm{dt}$ INIT RPE $=0$

\section{INFLOWS:}

Passive_diffusion_1 = Papp*RPE_surface_area*(Concentration_vitreous-Concentration_RPE)

\section{OUTFLOWS:}

Passive_diffusion_3 $=$ Concentration_RPE*Papp*RPE_surface_area

Passive_diffusion_2 = (Concentration_RPE-Concentration_vitreous) $*$ Papp*RPE_surface_area

Active_transport $=$ Vmax*Concentration_RPE/(Concentration_RPE+Km) 
Concentration_RPE $=$ RPE/Volume_RPE

Concentration_vitreous $=0.25-2500 \mu \mathrm{g} / \mathrm{ml}$

$\mathrm{Km}=0.1-1000 \mu \mathrm{g} / \mathrm{ml}$

Papp $=0.0006-0.000006 \mathrm{~cm} / \mathrm{min}$

RPE_surface_area $=12.04 \mathrm{~cm}^{2}$

RPE_thickness $=0.0014 \mathrm{~cm}$

$V_{\max }=0.01-0.1 \mu \mathrm{g} / \mathrm{min}$

Volume_RPE $=$ RPE_thickness $*$ RPE_surface_area 


\section{References}

Ahmed, I., Gokhale, R.D., Shah, M.V., Patton, T.F., 1987. Physicochemical determinants of drug diffusion across the conjunctiva, sclera, and cornea. J. Pharm. Sci. 76, 583-586.

Anand, B.S., Mitra, A.K., 2002. Mechanism of corneal permeation of L-valyl ester of acyclovir: targeting the oligopeptide transporter on the rabbit cornea. Pharm. Res. 19, 1194-1202.

Chrai, S.S., Patton, T.F., Mehta, A., Robinson, J.R., 1973. Lacrimal and instilled fluid dynamics in rabbit eyes. J. Pharm. Sci. 62, 1112-1121.

Curcio, C.A., Messinger, J.D., Sloan, K.R., Mitra, A., McGwin, G., Spaide, R.F., 2011. Human chorioretinal layer thicknesses measured in macula-wide, high-resolution histologic sections. Invest. Ophthalmol. Vis. Sci. 52, 3943-3954.

Dahlin, A., Geier, E., Stocker, S.L., Cropp, C.D., Grigorenko, E., Bloomer, M., Siegenthaler, J., Xu, L., Basile, A.S., Tang-Liu, D.D., Giacomini, K.M., 2013. Gene expression profiling of transporters in the solute carrier and ATP-binding cassette superfamilies in human eye substructures. Mol. Pharm. 10, 650-663.

Del Amo, E.M., Rimpela, A.K., Heikkinen, E., Kari, O.K., Ramsay, E., Lajunen, T., Schmitt, M., Pelkonen, L., Bhattacharya, M., Richardson, D., Subrizi, A., Turunen, T., Reinisalo, M., Itkonen, J., Toropainen, E., Casteleijn, M., Kidron, H., Antopolsky, M., Vellonen, K.S., Ruponen, M., Urtti, A., 2016. Pharmacokinetic aspects of retinal drug delivery. Prog. Retin. Eye Res.

Del Amo, E.M., Urtti, A., 2015. Rabbit as an animal model for intravitreal pharmacokinetics: Clinical predictability and quality of the published data. Exp. Eye Res. 137, 111-124.

Han, Y.H., Sweet, D.H., Hu, D.N., Pritchard, J.B., 2001. Characterization of a novel cationic drug transporter in human retinal pigment epithelial cells. J. Pharmacol. Exp. Ther. 296, 450-457.

Hariharan, S., Janoria, K.G., Gunda, S., Zhu, X., Pal, D., Mitra, A.K., 2006. Identification and functional expression of a carrier-mediated riboflavin transport system on rabbit corneal epithelium. Curr. Eye Res. 31, 811-824.

Jain-Vakkalagadda, B., Pal, D., Gunda, S., Nashed, Y., Ganapathy, V., Mitra, A.K., 2004. Identification of a $\mathrm{Na}+-$ dependent cationic and neutral amino acid transporter, $\mathrm{B}(0,+)$, in human and rabbit cornea. Mol. Pharm. 1, 338-346.

Karlgren, M., Vildhede, A., Norinder, U., Wisniewski, J.R., Kimoto, E., Lai, Y., Haglund, U., Artursson, P., 2012. Classification of inhibitors of hepatic organic anion transporting polypeptides (OATPs): influence of protein expression on drug-drug interactions. J. Med. Chem. 55, 4740-4763.

Katragadda, S., Talluri, R.S., Pal, D., Mitra, A.K., 2005. Identification and characterization of a Na+dependent neutral amino acid transporter, ASCT1, in rabbit corneal epithelial cell culture and rabbit cornea. Curr. Eye Res. 30, 989-1002.

Maurice, D.M., Mishima, S., 1984. Ocular pharmacokinetics. In: Sears, M.L. (Ed.), Handbook of experimental pharmacology. Springer Verlag, Berlin-Heidelberg, pp. 16-119.

Pitkanen, L., Ranta, V.P., Moilanen, H., Urtti, A., 2005. Permeability of retinal pigment epithelium: effects of permeant molecular weight and lipophilicity. Invest. Ophthalmol. Vis. Sci. 46, 641-646. 
Ranta, V.P., Laavola, M., Toropainen, E., Vellonen, K.S., Talvitie, A., Urtti, A., 2003. Ocular pharmacokinetic modeling using corneal absorption and desorption rates from in vitro permeation experiments with cultured corneal epithelial cells. Pharm. Res. 20, 1409-1416.

Steuer, H., Jaworski, A., Elger, B., Kaussmann, M., Keldenich, J., Schneider, H., Stoll, D., Schlosshauer, B., 2005. Functional characterization and comparison of the outer blood-retina barrier and the blood-brain barrier. Invest. Ophthalmol. Vis. Sci. 46, 1047-1053.

UCSF-FDA TransPortal database, http://transportal.compbio.ucsf.edu

Urtti, A., Pipkin, J.D., Rork, G., Repta, A.J., 1990. Controlled drug delivery devices for experimental ocular studies with timolol 2. Ocular and systemic absorption in rabbits. Int J Pharm 61, 241-249.

Vildhede, A., Mateus, A., Khan, E.K., Lai, Y., Karlgren, M., Artursson, P., Kjellsson, M.C., 2016. Mechanistic Modeling of Pitavastatin Disposition in Sandwich-Cultured Human Hepatocytes: A Proteomics-Informed Bottom-Up Approach. Drug Metab. Dispos. 44, 505-516.

Watsky, M.A., Jablonski, M.M., Edelhauser, H.F., 1988. Comparison of conjunctival and corneal surface areas in rabbit and human. Curr. Eye Res. 7, 483-486.

Zhang, N., Kannan, R., Okamoto, C.T., Ryan, S.J., Lee, V.H., Hinton, D.R., 2006. Characterization of brimonidine transport in retinal pigment epithelium. Invest. Ophthalmol. Vis. Sci. 47, 287-294. 